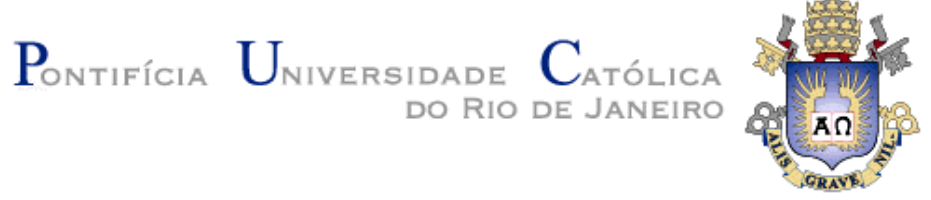

Tiago Lopes Rios

O cinema arqueológico de Patricio Guzmán

Dissertação de Mestrado

Dissertação apresentada como requisito parcial para obtenção do título de Mestre em Comunicação Social pelo Programa de Pós-Graduação em Comunicação Social da PUC-Rio.

Orientador: Profa. Angeluccia Bernardes Habert

Rio de Janeiro

Abril de 2014 
Tiago Lopes Rios

\section{O cinema arqueológico de Patricio Guzmán}

Dissertação apresentada como requisito parcial para obtenção do título de Mestre em Comunicação Social pelo Programa de Pós-Graduação em Comunicação Social da PUC-Rio. Aprovada pela Comissão Examinadora abaixo assinada.

Profa. Angeluccia Bernardes Habert

Orientadora

Departamento de Comunicação Social - PUC-Rio

Prof. Miguel Pereira

Departamento de Comunicação Social - PUC-Rio

Profa. Ana Paula Goulart Departamento de Comunicação Social - UFRJ

Profa. Mônica Herz Vice-Decana de Pós-Graduação do Centro de Ciências Sociais - PUC-Rio 
Todos os direitos reservados. É proibida a reprodução total ou parcial do trabalho sem autorização da universidade, do autor e do orientador.

\section{Tiago Lopes Rios}

Graduou-se em Comunicação Social pela PUC-Rio em 2010.

Ficha Catalográfica

Rios, Tiago Lopes

O cinema arqueológico de Patricio Guzmán / Tiago Lopes Rios ; orientador: Angeluccia Bernardes Habert. $-2014$.

107 f. : il. (color.) ; $30 \mathrm{~cm}$

Dissertação (mestrado)-Pontifícia Universidade Católica do Rio de Janeiro, Departamento de Comunicação Social, 2014.

Inclui bibliografia

1. Comunicação Social - Teses. 2. Patricio Guzmán. 3. Cinema latinoamericano. 4. Documentário. 5. Memória. 6. Nostalgia da luz. 7. Chile. 8. Memória. I. Habert, Angeluccia Bernardes. II. Pontifícia Universidade Católica do Rio de Janeiro. Departamento de Comunicação Social. III. Título.

CDD: 302.23 


\section{Agradecimentos}

À Profa. Dra. Angeluccia Bernardes Habert, pela orientação atenciosa e lúcida, pelas conversas que me levaram a descobrir a amplitude do trabalho de Patricio Guzmán.

À PUC-Rio, pelos auxílios concedidos, sem os quais este trabalho não poderia ter sido realizado.

Agradeço a minha companheira Itauana Fonseca Coquet, que me ajudou ao longo desses dois anos de estudos.

Sou grato, também, a dois cineastas que me ensinaram muito: Silvio Tendler, com quem tenho tido a oportunidade de trabalhar, o que me tem possibilitado o contato prático com assuntos políticos e culturais instigantes, e Patricio Guzmán, por ter me enviado pessoalmente cópias de alguns de seus filmes e por ser o documentarista que é. 


\section{Resumo}

Rios, Tiago Lopes; Habert, Angeluccia Bernardes. O cinema arqueológico de Patricio Guzmán. Rio de Janeiro, 2014. 107p. Dissertação de Mestrado - Departamento de Comunicação Social, Pontifícia Universidade Católica do Rio de Janeiro.

A partir do olhar sobre dois filmes de Patricio Guzmán realizados no Chile após o fim da ditadura de Pinochet (1973-1990) -Chile, memória obstinada (1997) e Nostalgia da Luz(2010) -, discute-se como ele desenvolve uma narrativa mais pessoal - sua guinada subjetiva e reflexiva sobre a história -, considerando, com particular atenção, a memória de seu país. Seus filmes expõem - o gesto arqueológico - não somente narrativas como que soterradas na memória dos entrevistados, que foram omitidas para as novas gerações, mas também a construção de atos corporais de memória e objetos comemorativos. Murais antigos e coloridos são descobertos por trás de grossas camadas de tinta monocrômica, da mesma forma que vestígios humanos e ruínas na árida paisagem do deserto de Atacama, deixando reemergir experiências e versões dos sofrimentos de vidas que, embora tendo ficado no passado, ainda estão fortemente presentes. Ao descrever e discutir detalhes de importantes sequências desses dois filmes, procura-se mostrar como eles obstinadamente resistem e, de forma meditativa, revertem o esquecimento e a ocultação que a história oficial tem sustentado.

\section{Palavras-chaves}

Patricio Guzmán; cinema latinoamericano; documentário; memória; Nostalgia da Luz; Chile, memória obstinada. 


\section{Abstract}

Rios, Tiago Lopes; Habert, Angeluccia Bernardes (Advisor). The archeological cinema of Patricio Guzmán. Rio de Janeiro, 2014. 107p. MSc. Dissertation - Departamento de Comunicação Social, Pontifícia Universidade Católica do Rio de Janeiro.

Focusing mainly on two films by Patricio Guzmán, produced in Chile after the end of the Pinochet dictatorship (1973-1990) - Chile, obstinate memory (1997) and Nostalgia for the Light (2010), we comment on how he develops a personal and subjective narrative with a particular attention to the memory of his country's and people's past. His films bring out - and that is what we call the archeological gesture - not only narratives which are buried in the memories of the interviewees and had been kept untold (out of reach particularly of the new generation), but also objects like old vivid mural pictures covered up by a non-descriptive coat of paint, as well as remains and ruins of the arid landscape of the Atacama desert, letting reemerge experiences and versions of the past, though still strongly present, lives of suffering. It was mainly when we describe in detail and attentively comment on important sequences of these two films that we succeeded in showing how they obstinately resist and revert the forgetting and obliteration of the accommodating official story.

\section{Keywords}

Patricio Guzmán; Latin American; documentary; memory; Nostalgia for the Light; Chile, obstinate memory 


\section{Sumário}

Introdução

1. Os primeiros anos e a batalha no Chile 20

1.1 O engajamento de Patricio Guzmán 22

1.2 A Batalha do Chile 24

2. Chile, memória obstinada, uma ponte por cima da ruptura 32

2.1 A memória como preocupação histórica 36

2.2 Álbum de fotografia 43

2.3 Atos de memória corporizados 49

2.4 Ponte por cima da ruptura 54

3. Nostalgia da Luz e o gesto arqueológico 56

3.1 Pelas paisagens áridas $\quad 59$

3.2 O gesto arqueológico $\quad 65$

3.3 A socialização da memória "pré-histórica acusatória" do Chile 73

3.4 Luís Henríques e Miguel Lawner, os transmissores da história 76

$\begin{array}{ll}3.5 \text { Imagens cristalinas, corpos estrelares } & 79\end{array}$

3.6 "Talvez muitos dirão, para que queremos ossos" 83

$\begin{array}{ll}3.7 \text { Nostalgia reflexiva e o deserto como arquivo } & 87\end{array}$

4. Considerações finais 92

$\begin{array}{ll}\text { 5. Filmografia } & 98\end{array}$

$\begin{array}{lr}\text { 6. Referências Bibliográficas } & 102\end{array}$ 


\section{Lista de figuras}

Figura 1 - O congelamento da imagem e o trabalho de emolduramento

Figura 2 - O congelamento da imagem e o trabalho de emolduramento

Figura 3 - O congelamento da imagem e o trabalho de emolduramento

Figura 4 - O palácio em chamas em 1973

Figura 5 -Os soldados no mesmo local em 1996

Figura 6 - Fotogramas da sequência da sacada do Palácio de La Moneda

Figura 7 - Fotogramas da sequência da sacada do Palácio de La Moneda

Figura 8 - Fotogramas da sequência da sacada do Palácio de La Moneda

Figura 9 - A utilização da fotografia na sequência do Pintor Balmes $\quad 45$

Figura 10 - A utilização da fotografia na sequência do Pintor Balmes 45

Figura 11 - A utilização da fotografia na sequência do Pintor Balmes 45

Figura 12 - A utilização da fotografia na sequência do Pintor Balmes

Figuras 13 - Exemplos das diversas formas de utilização da imagem fixa no filme Chile, memória obstinada

Figura 14 - Exemplos das diversas formas de utilização da imagem fixa no filme Chile, memória obstinada

Figura 15 - Exemplos das diversas formas de utilização da imagem fixa no filme Chile, memória obstinada

Figura 16 - A música "Venceremos" começa a ser tocada na rua

e termina numa sala de projeção

Figura 17 - - A música "Venceremos" começa a ser tocada na rua e termina numa sala de projeção

Figura 18 - Fotogramas da sequência da escolta do carro de Salvador Allende

Figura 19 - Fotogramas da sequência da escolta do carro de 
Figura 20 - Fotogramas da sequência da escolta do carro de Salvador Allende

Figura 21 - Fotogramas onde ouvimos a sonata de Beethoven

Figura 22 - Fotogramas onde ouvimos a sonata de Beethoven

Figura 23 - Fotogramas onde ouvimos a sonata de Beethoven

Figura 24 - Sequência do tio Ignacio ao piano

Figura 25 - Sequência do tio Ignacio ao piano

Figura 26: Fotograma retirado de seu filme $A$ Batalha do Chile

Figura 27 - Imagens do deserto no filme $O$ caso Pinochet

60

Figura 28 - Imagens do deserto no filme $O$ caso Pinochet 60

Figura 29 - Imagens do deserto no filme $O$ caso Pinochet 60

Figura 30 - A maquete e o desenho como formas de

reconstrução de Villa Grimaldi

Figura 31 - A maquete e o desenho como formas de reconstrução de Villa Grimaldi

Figuras 32 - O gesto arqueológico de Patricio Guzmán em Salvador Allende

Figura 33 - O gesto arqueológico de Patricio Guzmán em Salvador Allende

Figura 34 - O gesto arqueológico de Patricio Guzmán em Salvador Allende

Figura 35 - Ema Malig diante de seu quadro

Figura 36 - Efeito especial de 'pó cósmico' que se justapõe à imagem

Figura 37 - Luís Henríquez recorda os nomes dos presos políticos em Chacabuco

Figura 38 - Exemplos de uma planta baixa e de um desenho das técnicas de tortura mostradas no filme

Figura 39 - Exemplos de uma planta baixa e de um desenho das técnicas de tortura mostradas no filme

Figura 40 - Mãe do jovem engenheiro Víctor tratando uma

ex-torturada e seu reflexo no espelho

Figuras 41 - Aproximação feita entre a imensidão do Universo e do deserto de Atacama 
Figura 42 - Aproximação feita entre a imensidão do Universo e do deserto de Atacama

Figura 43 - Imagem da superfície lunar seguida da

imagem da superfície de um crâneo: representação do cálcio que constitui ambos

Figura 44 - Imagem da superfície lunar seguida da

imagem da superfície de um crâneo: representação do cálcio que constitui ambos 
Eu tinha vontade de fazer como os dois homens que vi sentados na terra escovando osso. No começo achei que aqueles homens não batiam bem. Porque ficavam ali sentados na terra o dia inteiro escovando osso. Depois aprendi que aqueles homens eram arqueólogos. E que eles faziam o serviço de escovar ossos por amor. E que eles queriam encontrar nos ossos vestígios de antigas civilizações que estariam enterrados por séculos naquele chão. Logo pensei de escovar palavras. Porque eu havia lido em algum lugar que as palavras eram conchas de clamores antigos. Eu queria ir atrás dos clamores antigos que estariam guardados dentro das palavras. Eu já sabia também que as palavras possuem no corpo muitas oralidades remontadas e muitas significâncias remontadas. Eu queria então escovar as palavras para escutar o primeiro esgar de cada uma. Para escutar os primeiros sons, mesmo que ainda bígrafos. Comecei a fazer isso sentado em minha escrivaninha. Passava horas inteiras, dias inteiros fechado no quarto, trancado, a escovar palavras. Logo a turma perguntou: o que eu fazia o dia inteiro trancado naquele quarto? Eu respondi a eles, meio entressonhado, que eu estava escovando palavras. [...] 


\section{Introdução}

Miguel e sua esposa são, para mim, como uma metáfora sobre o Chile: ele é a recordação enquanto Anita, por causa da doença do Mal de Alzheimer, é o esquecimento

(Narração do filme Nostalgia da Luz)

Esta pesquisa analisa e comenta os principais documentários de Patricio Guzmán, descrevendo suas estratégias tanto na realização das imagens e entrevistas quanto na montagem e narração. O que está em questão no trabalho de Guzmán é sobretudo o resgate das memórias silenciadas durante o regime militar de Augusto Pinochet (1973-1990). Desse modo, apresentamos seu engajamento com o cinema político, iniciado ainda no início da década de 70 , num período de intensificação da Guerra Fria no continente sul-americano. No primeiro capítulo, comentamos seus primeiros filmes e La batalha de Chile: La lucha de un Pueblo sin armas [A Batalha do Chile: a luta de um Povo sem armas] (1975-79). No segundo capítulo, discutiremos, mais detidamente Chile, la memoria obstinada [Chile, memória obstinada] (1997). Ao final, no terceiro capítulo, desenvolvemos a análise de seu último documentário, La Nostalgia de la Luz [Nostalgia da Luz] (2010).

Nostalgia da Luz é o relato em primeira pessoa sobre a relação entre ciência, política e vida cotidiana. $\mathrm{O}$ deserto de Atacama é o cenário em que as linhas narrativas que compõem o documentário de Guzmán se entrecruzam, tanto nos apresentando vidas e eventos quanto nos instigando a pensar. Não é um documentário centrado na denúncia - o caráter criminoso da ditadura chilena já é bem conhecido -, embora não deixe de mostrar diversas consequências nefastas dela, assim como os sofrimentos humanos que persistem, mas, indo adiante, soma ao trabalho de restituição da memória uma dimensão meditativa que humaniza tanto a voz narrativa quanto o olhar do espectador. Nesse filme, convergem, por exemplo, diálogos acadêmicos - no caso, entre astrônomos e arqueólogos -, que convencionalmente permanecem isolados, alcançando o resultado de potencializar a questão da busca da humanidade por suas origens no passado remoto que, paradoxalmente, pode conviver com forças que, ainda que contestadas, buscam ocultar e fazer esquecer o passado próximo da ditadura. Ao fazer isso, Guzmán 
elabora questões desafiadoras e controversas sobre a construção dos significados históricos e da importância para ela do relembrar e do esquecer, da melancolia e do luto.

Há atualmente um amplo debate sobre a questão da memória. Um dos autores pioneiros nesse tema é Maurice Halbwachs, sociólogo francês morto no campo de concentração de Buchenwald em 1945. Embora não tenhamos a proposta de apresentar sua obra, reconhecemos que sua leitura nos foi importante. De fato, ele desenvolve a ideia de que as memórias individuais são construídas e elaboradas a partir de referências e lembranças dos grupos que a cercam, constituindo-se, portanto, como memórias coletivas. A formação da memória no indivíduo estaria sujeita a representações do passado de seus grupos e nas imagens que criamos dos acontecimentos que entendemos ter acontecido, ou seja, pela internalização da memória histórica que, elaborada coletivamente, se nos apresenta. Ele diz:

a lembrança é em larga medida uma reconstrução do passado com a ajuda de dados emprestados do presente, e além disso, preparada por outras reconstruções feitas em épocas anteriores e de onde a imagem de outrora manifestou-se já bem alterada (Halbwachs, 2004: pp. 75-6)

Guzmán, por sua vez, também, de modo semelhante a Halbwachs, parte do presente, do que se apresenta a ele: a paisagem do deserto de Atacama, buscando resgatar memórias individuais e, assim, discutindo o legado traumático desses testemunhos em uma sociedade em que a transição do governo militar para o democrático se deu de forma, em muito, monitorada pelo exército e, em especial, pelo próprio Pinochet, que permaneceu como Comandante-Chefe do Exército do Chile até 1998 (quando se tornou senador vitalício). No âmbito estritamente oficial, as medidas mais importantes tomadas pelos presidentes eleitos democraticamente foram a criação da Comissão Rettig (1990) e da Comissão Valech (2003). Apesar das críticas, assim como das limitações próprias ao caráter jurídico dessas comissões (que produzem narrativas balizadas pela própria proposta de terem validade em tribunais), é possível reconhecer que, embora juridicamente, sem dúvida, haja ainda extenso trabalho a ser feito, essas duas comissões foram relevantes para o trabalho de memória no Chile. No entanto, como se vê em Nostalgia da Luz, o fato de que há tantos corpos de vítimas da 
ditadura que permanecem desaparecidos e de que a ajuda no esclarecimento do local em que foram descartados ou do processo que os destruiu é precária, mostra a insuficiência de como o passado ditatorial foi, é, e continua sendo lidado. Além disso, Nostalgia da Luz, com sua narrativa múltipla e meditativa - rememoração que se faz aos poucos, em um processo de descobertas paulatinas de traços físicos e materiais -, amplia o trabalho da memória para muito além da moldura jurídica.

A trajetória de Guzmán está diretamente relacionada com a história e a memória do Chile. El Equipo Tercer Año, como ficou conhecido o pequeno grupo de cineastas encabeçados por Guzmán em 1972, via no cinema a possibilidade de documentar o conturbado momento político no Chile, que se intensificara com a vitória de Salvador Allende, nas eleições presidenciais de setembro de 1970, como candidato da Unidade Popular (UP) ${ }^{1}$.

De fato, muitos artistas e intelectuais apoiaram com entusiasmo as propostas de Allende em promover uma "via chilena ao socialismo" - que a um só tempo dependia e defendia a democratização e a solidez das instituições estatais e buscaram vivenciar de perto o que seria, nas palavras de Allende, "um segundo caminho para o socialismo", "dentro dos marcos do sufrágio, em democracia, pluralismo e liberdade" (Allende apud Aggio, 2002:44). Alberto Aggio, em seu estudo sobre a "experiência chilena", ressalta a importância desse momento para o pensamento das esquerdas:

\begin{abstract}
As atenções de boa parte do mundo voltaram-se para aquele país que, com a ascensão de Salvador Allende à presidência da República, passava a viver uma situação inédita. Pela primeira vez na História, um presidente declaradamente marxista chegava ao poder através de eleições gerais e livres e propunha implantar o socialismo como resultado de seu programa eleitoral (Aggio, 2002:15).
\end{abstract}

Naquele momento, já instigado pelo trabalho colaborativo no filme $\grave{A}$ Valparaiso (1962) de Joris Ivens, Chris Marker, importante e influente cineasta francês, que entre os anos 60 e 70 já se dedicava a filmar os processos revolucionários que ocorriam na América Latina, em especial a Revolução Cubana, quando realizou filmes como Cuba si (1961) e La bataille des diz millions (1970), viaja, em 1972, para o Chile da Unidade Popular. Nessa passagem pelo

\footnotetext{
${ }^{1}$ Coalisão política que tinha como e eixo os partidos Comunistas e Socialistas, mas que abrigava também radicais (PR), social-democratas (PSD), a Ação Popular Independente (API) e parte da esquerda católica, o Movimento de Ação Popular Unificado (MAPU).
} 
país, Chris Marker conhece Patricio Guzmán através do documentário El primer Año (1971), um filme sobre os primeiros doze meses de Allende no poder, cujo interesse faz com que ele fosse à casa de Guzmán pedir sua autorização para levar uma cópia para fora do país. Marker, de volta à França, vai reeditá-lo - já após o golpe de 1973 - para a exibição na França. Desse encontro Guzmán recorda: “Já se passaram quarenta anos desde essa conversa e somente há pouco tempo descobri que marcou minha vida para sempre, já que minha modesta carreira de cineasta novato deu uma virada enorme a partir desse momento" (Guzmán, 2012.c:s/p).

O compromisso político - uma espécie de militância por parte dos cineastas - encontrou no documentário um espaço formal que privilegia o debate e sua tomada de posição diante do mundo bipartido. A intelectualidade latinoamericana começou então a colocar na linha de frente questões como a colonização/descolonização; alienação/desalienação e a entender o cinema como uma forma de arte fomentadora da emancipação do povo, junto com o qual construiria uma cultura autenticamente nacional.

Em resposta a isso, tendo em vista os movimentos europeus do pós-guerra, como o Neo-realismo na Itália e, posteriormente, a Nouvelle Vague na França, diversas declarações de princípios estético-políticos surgiram pelos países latinos americanos, no que ficou conhecido como o Novo Cinema Latino Americano. No Chile, ainda durante a campanha de Allende, apareceu o Manifesto de los Cineastas de la Unidade Popular (1970), cuja autoria é atribuída a Miguel Littín, importante cineasta que assumiu a direção da Chile Films após a vitória da UP. Esse manifesto tem influência direta em Por un cine imperfecto (1969), do cubano Julio García Espinosa (que veio a ser colaborador de $A$ Batalha do Chile quando Guzmán montou o filme em Cuba). Em seu texto, Espinosa chama atenção de que não existe uma linguagem cinematográfica acabada, "para o cinema imperfeito não interessa mais a qualidade nem a técnica" (Espinosa, 1970:42). No Brasil, a alternativa ao cinema industrial - um posicionamento a favor da descolonização cultural - foi o Cinema Novo, onde a aspiração de uma juventude que "sentia-se representante dos interesses do ocupado e encarregada de função mediadora no alcance do equilíbrio social" (Gomes, 1986:102). Glauber Rocha, principal figura do movimento, apresentou em 1965 a tese-manifesto "Uma Estética da Fome" - 
ou, como ele preferia escrever, Estétyka da Fome ${ }^{2}$. Aqui, Glauber já antecipava, antes de Espinosa, uma estética que nasce do subdesenvolvimento, da fome, da imperfeição: “O Cinema Novo é um projeto que se realiza na política da fome, por isto mesmo, todas as fraquezas consequentes de sua existência” (Rocha, 1965:s/p). Nesse mesmo contexto, na Argentina, surgiu o manifesto Hacia un tercer cine (1969) de Octavio Getino e Fernando Solanas.

No entanto, esse período fecundo foi brutalmente interrompido por golpes militares. No Chile, após o 11 de setembro de 1973, o exílio se tornou a condição da própria sobrevivência. O exílio forçado estimulou o fenômeno do "cinema da diáspora": em um pouco mais de dez anos de regime militar são produzidos no exílio 155 filmes de cineastas chilenos espalhados por 16 países diferentes (Pick, 1987:66). A violenta repressão impossibilitou ao longo dos primeiros anos qualquer tipo de cinema clandestino no país; no entanto, ao longo da década de 80 , com o surgimentos das câmeras digitais e do suporte VHS, "um cinema silencioso e anônimo" voltou a aparecer no país (Ruffinelli, 2001:193) 3 $^{3}$ De fato, cineastas importantes regressam clandestinos ao país para filmarem: é o caso de Miguel Littín com Ata Geral do Chile (1986) e Patricio Guzmán, no mesmo ano, com En nombre de Dios (1986).

No primeiro capítulo, apresentaremos o início da vida estudantil e profissional de Guzmán, até chegarmos a sua primeira grande realização: $A$ Batalha do Chile. Dessa forma, para compreender as forças políticas envolvidas e as relações de poder que Guzmán filmou, apresentamos um breve panorama histórico.

A Batalha do Chile: a luta de um povo sem armas, filme dividido em três partes (A insurreição da burguesia de 1975, O golpe militar de 1976 e O poder popular de 1979) com mais de quatro horas de duração, tornou-se uma espécie de epítome do Novo Cinema Latino Americano: direto, engajado, imediato, espontâneo e analítico. Mesmo assim, essa trilogia tem sido pouco divulgada no Chile. Ainda que juridicamente não se possa mais usar a palavra "censura", há que se reconhecer que $A$ Batalha do Chile, até os dias de hoje, nunca foi transmitida

\footnotetext{
${ }^{2} \mathrm{O}$ texto do manifesto foi escrito durante a viagem de avião entre Los Angeles e Milão, para o congresso Terceiro Mundo e Comunidade Mundial.

${ }^{3}$ Todas as traduções de textos em espanhol e inglês, incluído também as transcrições de filmes, nesse trabalho, foram feitas por mim.
} 
pela televisão pública, nem estreou nas salas comerciais. No entanto, durante os anos 70 e 80, foi exibido em 35 países e ganhou seis grandes prêmios ${ }^{4}$. Esse filme (como os demais de Guzmán) não só busca trabalhar a memória, repensar a história, como indica deficiências no trabalho de memória que acontece no Chile, do que é um sintoma a não exibição desses filmes de Guzmán nos canais abertos de televisão.

No segundo capítulo, vemos como o filme Chile, memória obstinada (1997), feito no momento de redemocratização do país, inaugura uma nova abordagem do diretor na forma de uma participação mais presente - performática - dentro do filme. Além do uso da narração em primeira pessoa, Guzmán constrói seu filme a partir das imagens de A Batalha do Chile; desta forma, a partir de um exercício de metalinguagem - o filme dentro do filme -, ele consegue localizar e identificar, junto a outros personagens, algumas pessoas que fizeram parte de seu filme anterior e que sobreviveram ou são parentes de vítimas do período ditatorial. Descrevo também as práticas do diretor com relação ao uso da fotografia como ferramenta provocadora das memórias em alguns personagens; seu uso também abre novas interpretações para os espaços do presente e possibilita a transmissão de uma experiência passada, algo que se torna importante na elaboração das memórias das novas gerações, muitas vezes filhos de vítimas da ditadura, permitindo a formação, nesses casos, de uma "pós-memória" sobre o passado que não foi vivenciado diretamente. Nas palavras de Hirsch:

A pós-memória descreve, mais especificamente, o relacionamento dos filhos dos sobreviventes de um trauma coletivo ou cultural com as experiências de seus pais, experiências que eles "lembram" apenas enquanto narrativas e imagens com as quais eles cresceram, mas que são tão fortes, tão monumentais, que constituem memórias por si só (Hirsch, 2001:218-219).

Tanto Chile, memória obstinada como filmes mais recentes como Salvador Allende (2004) e El caso Pinochet [O caso Pinochet] (2001), antecedem vários gestos que estão presentes em Nostalgia da Luz. Neles, o método consiste em transgredir o passado na estrutura material da cidade, na preocupação mais atenta pela materialidade dos objetos desse passado. Existe no trabalho de Guzmán o que

\footnotetext{
${ }^{4}$ Gran Premio Festival de Grenoble. Francia, 1975; Gran Premio Festival de Grenoble. Francia, 1976; Gran Premio del Jurado. Festival Internacional de Leipzig. Alemania, 1976; Gran Premio Festival Internacional de Bruselas. Bélgica, 1977; Gran Premio Festival Internacional de Benalmádena. España, 1977; Gran Premio Festival Internacional de la Habana. Cuba, 1979.
} 
chamaremos de um gesto arqueológico, onde seus documentários constroem seu objeto como um contra-discurso ao propor uma arqueologia do presente que redefine esse tempo, julgando as origens de seus conflitos e tensões, suas contradições e pontos cegos. O gesto arqueológico, sua vontade de ativar a memória através de resquícios, ruínas e artefatos visuais, que vincula o presente a períodos históricos anteriores, se tornou uma característica no cinema de Guzmán nos últimos anos. Essa sua forma de filmar articula em muitos aspectos uma atitude do "historiador materialista" que Walter Benjamin descreve em seu texto "Sobre o conceito da História". Benjamin usa a imagem do Angelus Novus presente em um desenho de Paul Klee de 1920. Ali o anjo se encontra com a face voltada para o passado; no entanto, uma tempestade (que seria o progresso para o autor) força suas asas e o empurra para o futuro, nesse caminho o anjo "acumula incansavelmente ruína sobre ruína e as dispersa sobre nossos pés” (Benjamin, 1987:226). A perspectiva histórica de Benjamin, tal como o anjo figura, é de observar o passado não mais espacialmente dividido e quantitativamente percebido, mas sim de uma maneira qualitativa onde se faz um resgate das memórias dos fracassados (dos acontecimentos, eventos e pessoas que não foram contempladas pela História Oficial) tal como elas se apresentam no presente. Assim, "muito antes de olhar para o futuro, o historiador materialista preza escutar as vozes do passado" (Penido, 1989:63). Podemos pensar que Guzmán também assume essa postura histórica ao articular sua arqueologia cinematográfica - de garimpar o passado para dar prosseguimento ao futuro - indo na contracorrente da história oficial, pois, como ele aponta, em seu país "não existe um cultivo da memória” (Guzmán, 2011.a:s/p); assim, como aponta Benjamin na tese $\mathrm{n}^{\mathrm{o}} 7$ do texto, ao "escovar a história a contrapelo" (Benjamin, 1987:225) - tal como os pequenos e delicados instrumentos de trabalho arqueológico -, ele quer encontrar os fragmentos/rastros/resquícios para poder resignificá-los no presente. Dessa maneira, como comenta a socióloga Macarena Gómez-Barris: “Guzmán produz uma linguagem cinematográfica da memória social, com o objetivo de reformular a reconstrução histórica dos eventos da ditadura" (2010:122).

O terceiro capítulo da pesquisa vai justamente abordar esse trabalho arqueológico em sua forma de construir um conhecimento histórico a partir de restos materiais. Discutimos, então, como Nostalgia da Luz elabora as problemáticas já levantadas e apontadas nos outros documentários. Nostalgia da 
$L u z$ entrelaça em sua narrativa três grupos que compartilham o mesmo espaço na tentativa de obterem resposta para seus interesses particulares sobre o passado. Astrônomos procuram a origem da vida, buscando detectar a energia do Big Bang, enquanto arqueólogos traçam as rotas dos povos pré-colombianos ao encontrarem pinturas rupestres e múmias. Por sua vez, um pequeno grupo de mulheres, na infinita paisagem do deserto, procuram os restos ósseos de seus familiares desaparecidos, que tiveram os corpos clandestinamente enterrados, depois descuidadamente desenterrados e, por fim, provavelmente jogados ao mar pela máquina da morte da organização da Junta militar. Além dos sofrimentos dessa árdua busca, essas mulheres também acabam por se tornarem excluídas da sociedade. O historiador Enrique Serra Padrós indica o quanto o silêncio oficial leva à exclusão dos que sofreram (e, no caso, ainda sofrem) com crimes das instituições governamentais:

O não-dito, o esquecimento e o silêncio oficial sobre os desaparecidos latinoamericanos induzem a reconhecê-los como uma categoria social que sofre o processo da exclusão histórica e inscreve-os dentro do espaço das memórias subterrâneas constituindo assim, pelo menos segundo as pretensões anestésicas plantadas pelo poder vigente, um grupo sobre o qual se quer que nada seja conhecido (Padrós, 2002:s/p).

Os filmes de Guzmán, com sua arqueologia da história chilena, justamente dão destaque a grupos excluídos e marginalizados, como, em Nostalgia da Luz, é o caso dessas mulheres do deserto de Atacama, para que, com isso, se façam conhecidas essas "memórias subterrâneas", que, na compreensão de Michael Pollack, são memórias que lutam contra a "História Oficial" e que buscam invadir o espaço público para entrarem na disputa da memória (Polack, 1989). 


\section{1. \\ Os primeiros anos e a batalha no Chile}

Para o observador europeu, os processos de produção artística do mundo subdesenvolvido só o interessam na medida que satisfazem sua nostalgia do primitivismo.

(Glauber Rocha)

A Revolução Cubana, com a derrubada de Fulgencio Batista em 1959 e a chegada ao poder do Movimento de 26 de Julho, liderado por Fidel Castro, teve repercussões profundas na vida política e cultural da América Latina. Em um período marcado pela Guerra Fria, a América Latina era área de influência norteamericana, uma importante zona estratégica no ordenamento da geopolítica global. Começando com o golpe no Peru, em 1962, e no Brasil, em 1964, quase todos os países latino-americano, com apoio dos Estados Unidos, foram, até antes do final dos anos 1970, se tornando ditaduras militares. No entanto, tanto no Brasil quanto em outros países, o campo cultural seguiu em atividade: obras importantes da literatura foram publicadas ${ }^{5}$, a música popular se mostrou criativa, sobretudo com marcantes "canções de protesto"6 e o cinema se impôs com o início do movimento chamado Novo Cinema Latino-americano.

Jaqueline Mouesca, uma das principais historiadoras do cinema chileno, observa, no entanto, que a onda revolucionária vinda de Cuba não tem influência direta na evolução da situação política em seu país: “A Unidade Popular, que se organiza nesses anos e que culmina com o triunfo de Salvador Allende em 1970, é um fenômeno que tem raízes próprias em nossa história, sua gestação vem de longe e corresponde a condicionamentos especificamente nacionais" (Mouesca, 2005: 68). De toda a forma, é no âmbito cultural que a influência externa se mostra mais presente; de fato, os movimentos La Nueva Canción Chilena e o Nuevo Cine Chileno seguem o mesmo compasso dos movimentos latino-americanos.

\footnotetext{
${ }^{5}$ Tendo como principais nomes o argentino Júlio Cortázar com seu livro O Jogo da Amarelinha (1963) e o colombiano Gabriel Garcia Márquez com o romance clássico do realismo mágico 100 anos de solidão (1967).

${ }^{6}$ Nesse cenário o intercâmbio entre os compositores foi bastante marcante, fazendo muitos artistas como Milton Nascimento, Mercedes Sosa, Chico Buarque, Caetano Veloso, Gilberto Gil, León Gieco, Sílvio Rodrigez dividirem palco. A exemplo disso temos musicas como: Volver a los dieciesiete da poetisa chilena Violeta Parra, gravada no álbum Geraes (1974) de Milton Santos e Canção para unidade latino-americana de Chico Buarque e do cubano Pablo Milanés.
} 
Em Viña del Mar, na costa do Chile, se realiza, em 1967, o Primeiro Festival do Novo Cinema Latino-americano (Primer Festival de Nuevo Cine Latinoamericano $)^{7}$, convocado pelo Cine-Club de Viña del Mar, dirigido pelo cineasta Aldo Francia.

Será, em um momento crucial da vida no Continente, uma expressão de unidade e solidariedade em um campo cultural que começava a mostrar uma vitalidade até então desconhecida, o começo do que ficaria conhecido como Novo Cinema Latino-americano (Mouesca, 1988: 31-32).

Dois anos depois, é realizado o Segundo Festival, em que participam algumas figuras essenciais do cinema latino-americano emergente: o brasileiro Glauber Rocha, que além de seu trabalho fílmico se apresenta como teórico da "estética da fome"; o grupo boliviano Uka-mau, que expõem os princípios do denominado "cinema combatente"; o argentino Fernando Birri, que fala em "documentar o subdesenvolvimento, enquanto seus compatriotas Fernando Solanas e Osvaldo Getino apresentavam sua tese Hacia um tercer cine ${ }^{8}$ (Mouesca, 2005: 69).

O ano de 1970 chega em meio a grande fervor político. Salvador Allende, da coalizão da Unidade Popular, fica em primeiro lugar nas eleições presidenciais com $36,2 \%$, contra $34,9 \%$ de Jorge Alessandri, candidato da direita e $27,8 \%$ de Radomiro Tomic, do Partido Democrata Cristão (Aggio, 1993: 107). Sem ter conquistado a maioria absoluta, a constituição chilena de 1925, vigente na época, previa a realização de um segundo turno, desta vez de forma indireta, por meio dos votos dos membros do Congresso Nacional, que decidiriam entre os dois candidatos com mais votos quem assumiria a presidência. Com pequena vantagem na votação, a eleição de Allende era incerta. No entanto, foi a Direita que, com apoio da CIA, ao tentar sequestrar o Comandante das Força Armadas, general René Schneider, visando causar uma situação de instabilidade que possibilitasse a intervenção do exército, o feriu gravemente, vindo a morrer. $\mathrm{O}$ assassinato levou à

\footnotetext{
${ }^{7}$ Essa é a quinta edição do Festival Viña del Mar: sua primeira versão se chamou Primer Festival Internacional de Cine Aficionado de Viña del Mar (1963) se mantendo com esse nome até sua quarta versão quando passou a se chamar Primer Festival de Cine Chileno (1966).

${ }^{8} \mathrm{O}$ "Terceiro Cinema" seria uma alternativa - que propunha uma produção independente, ideológica e com linguagem inovadora visando as questões políticas importantes - ao "Primeiro Cinema" (cinema norte-americano destinado ao entretenimento) e ao "Segundo Cinema" (produção europeia da política de autores).
} 
comoção a opinião pública e, assim, à ampliação dos parlamentares favoráveis a Allende, que, desse modo, foi confirmado.

Em novembro, Allende assume a presidência. Apesar da euforia de seus partidários com a chegada pacífica de um presidente socialista ao poder por vias democráticas, o que se inicia é o dramático período de mil dias que se caracterizará por um clima de crescente turbulência e conflitos. Ainda assim, o clima cultural parece se alimentar dessa tensão: é lançado o Manifesto dos Cineastas da Unidade Popular. Dos treze pontos destacados pelo Manifesto, o primeiro é talvez o que resume melhor a posição de seus participantes: "1. Que antes de cineastas, somos homens comprometidos com o fenômeno político e social de nosso povo e com sua grande tarefa: a construção do socialismo" (1970: $\mathrm{s} / \mathrm{p})^{9}$.

\section{1 \\ O engajamento de Patricio Guzmán}

Patricio Guzmán nasceu em Santiago do Chile, em 1941. Sua família se mudou constantemente, o que levou a que ele viesse a estudar em diversas escolas ao longo de sua formação primária. Ingressou na Escola de Teatro da Universidade do Chile (1960) e nas faculdades de História (1961) e Filosofia (1962-65), que teve que abandonar por razões financeiras, vindo a trabalhar por quatro anos em um escritório de publicidade, o que, para ele, não era estimulante. Nesse período, ele começou a fazer alguns filmes em $8 \mathrm{~mm}$ com amigos. Foi quando sua mulher levou alguns de seus rolos para o Instituto Fílmico da Universidade Católica do Chile para que fizessem cópias. Rafael Sánchez que trabalhava no Instituto Fílmico se interessou pelas imagens, chamando Guzmán para ser colaborador do Instituto, o que o possibilitou realizar o curta-metragem de 10 minutos chamado Viva la Liberdad (1965). Dessa forma, seguiu, de dia, trabalhando com publicidade, passando, à noite, a se dedicar ao cinema. Seu curta metragem foi

\footnotetext{
${ }^{9}$ Texto completo disponível em http://www.rua.ufscar.br/site/?p=3059 (acessado em 14 de novembro de 2013)
} 
exibido no IV Festival de Viña (1966), “em meio de um absoluto e lógico desprezo de todos, porque a verdade é que o filme era péssimo" (Guzmán, 1973: s/p). Guzmán resolve, então, se dedicar mais ao cinema e consegue ser contratado para trabalhar como assistente no Instituto Fílmico. Como ganhava muito mal, a situação se inverte: de dia, trabalhava com cinema e, à noite, com publicidade. Ainda em 1966, ele realiza Electroshow, que teve certa repercussão no Festival de Viña de 1967, ganhando um prêmio de menção honrosa. Apesar do reconhecimento, a vida não ficou mais fácil para ele:

O Instituto Fílmico realmente tinha um ambiente muito complexo que, depois de Electroshow, se complicou ainda mais. Parece que o êxito que tive com o filme, as funções que eu havia organizado no Cine Arte e meu interesse em reunir os cineastas e tirar o Instituto de um clima medieval provocou mal-estar (ibidem).

Devido à dificuldade de continuar ali, ele resolve estudar fora e começa a buscar nova inserção em alguma outra instituição cultural. Sem sucesso, Guzmán propõe a sua mulher vender tudo que tinham para se mudarem para a Espanha. Guzmán viaja primeiro e, quinze dias depois, consegue trabalho em uma agência publicitária em Madrid. Já estabelecido, ele começa a se prepara para ser admitido na Escuela Oficial de Cinematografía (E.O.C). Após um estressante processo de admissão, consegue ser selecionado e ingressar. Por essa ocasião, Guzmán conhece o dramaturgo chileno Jorge Díaz, também vivendo em Madrid, tornandose muito amigos, vindo a trabalhar juntos em alguns roteiros de longa-metragem, que, porém, acabaram nunca filmados. No entanto, em uma de suas aulas práticas, ele faz La tortura (1968), que é um capítulo ampliado e modificado da obra de Díaz Introducción al elefante y otras zoologias. No ano seguinte, Guzmán filma El paraíso ortopédico (1969), considerado o melhor filme do curso naquele ano, recebendo ótimas críticas. Em 1970, finaliza os estudos e obtém o título de diretor e realizador. A perspectiva de trabalhar e ganhar dinheiro com publicidade em Madrid não era satisfatória para Guzmán.

Espanha era para mim muito atrativa, mas algo impede que um cineasta latinoamericano se realize em sua plenitude. Talvez para o romancista, que carrega consigo lembranças e imagens, essa realização seja possível. Mas o cineasta se depara com uma paisagem diferente, com rostos distintos, uma língua que não é a sua e uma geografia humana que não é a do seu país (ibidem). 
Guzmán regressa ao Chile em março de 1971, onde se reencontrar com David Benavente, o diretor da Escuela de Artes de la Comunicación de la U.C, com quem mantinha contato enquanto estudava na Espanha. Benavente tem a intenção de fazer um longa metragem dividido em episódios com a participação de outros importantes cineasta como Miguel Littín e Raul Ruiz. Ambos já estavam ocupados com outros filmes, e Patricio Guzmán apresentou sozinho o projeto de El primer año. Paralelamente, conversa na Chile Films ${ }^{10}$ com Jesús Martínez e Littín, que foi nomeado presidente da empresa com a eleição de Allende. Eles encomendam um curta documentário sobre as eleições municipais, que será, após a aprovação do projeto em maio de 71, incorporado no documentário El primer $a \tilde{n} o^{11}$, um filme sobre os doze primeiros meses de Allende. Em 1972, produzido também pela Chile Films, Guzmán realiza La respuesta de Octubre ${ }^{12}$. Este filme também será desmontado posteriormente para ser reutilizado na última parte de $A$ Batalha do Chile; por isso, não consta em nenhuma listagem da filmografia do diretor.

\section{3 \\ A Batalha do Chile}

El primer año é um documentário importante na carreira de Guzmán; será através dele que o diretor fará contato com Chris Marker e experimentará técnicas (como o uso de planos sequências e zoons) que estarão presentes na câmera de Jorge Müller Silva em A Batalha do Chile. Jorge Ruffinelli, em seu livro dedicado ao diretor chileno, aponta que, diferentemente de A Batalha do Chile, El primer año se estrutura dentro de um esquematismo ideológico, típico do cinema

\footnotetext{
${ }^{10}$ Chile Films é uma empresa estatal cinematográfica criada em 1942 no governo de Pedro Aguirre Cerda.

${ }^{11}$ Seu negativo original foi destruído pelos militares. Mas, na França, Chirs Marker conservou um negativo com a versão francesa do filme (informação colhida na tese The postdictatorial documenraries of Patricio Guzmán: Chile, obstinate memory; The Pinochet case and Island of Robinson Crusoe de José Carlos Rodríguez).

${ }^{12}$ Respuesta de Octubre estreou em novembro de 1972 nos circuitos móveis da Chile Films. Esses circuitos eram unidades de projeções montados em caminhões que exibiam filmes nos bairros populares e fábricas nos arredores de Santiago. Seu filme ganhou o "Premio Cicuitos Móviles 1972".
} 
militante daquele momento no qual uma visão dicotômica da história prevalece em vez de uma mais dialética.

Depois do encontro durante a passagem de Chris Marker pelo Chile, Guzmán aceita o pedido de Marker para que ele pudesse reeditar seu filme. O diretor francês corta algumas sequências estritamente locais e produz um prólogo com fotos fixas. Sua versão francesa (La première année) é então distribuída na Europa pelo seu coletivo SLON (Service de Lancement des (Euvres Nouvelles).

Algo inimaginável estava acontecendo. Porque El primer año era um filme humilde (em 16 milímetro), sem som sincrônico, de orçamento superficial, que não tinha mais ambições do que mostrar a alegria dos obreiros, trabalhadores e mineiros durante o primeiro ano de Allende. Não podia ter mais horizonte do que 6 cópias em 35 milímetros e que fora exibida somente algumas semanas em poucas salas chilenas. No entanto, graças a Chris, El primer año foi exibido em muitas cidades da França, Bélgica e Suíça; ganhou o festival de Nantes e obteve o premio FIPRESCI em Mannheim (Guzmán, 2012.c: s/p).

Patricio Guzmán não foi o único diretor que se propôs a filmar o primeiro ano do processo socialista do Chile. Miguel Littín faz Compañeiro Presidente (1971), onde filma as conversas do presidente Salvador Allende com o filósofo francês Régis Debray. Porém o filme de Littín permanece em uma esfera mais privada, funcionando como um "insider" - valendo-se de duas figuras internacionalmente conhecidas -, enquanto Guzmán, ao sair para as ruas para acompanhar de perto os desdobramentos políticos em sua dimensão mais prática, funcionou como um "outsider" dos círculos de poder - aqui a lógica é lançar o foco para outro tipo de protagonista, isto é, o coletivo que apoia a UP: os mineradores, operários e camponeses (Ruffinelli, 2001:115). Marker também se apropria do filme de Littín e lança pela SLON, em 1973, o curta-metragem de 14 minutos On vous parle du Chili: ce que disait Allende. No qual também pode ser visto sua característica montagem de fotos fixas no prólogo do filme.

Após ter feito El primer año e La respuesta de Octubre, Guzmán resolver reagrupar as equipes desses seus primeiros filmes (Mülles, Elton, Menz, Pino) e com a ajuda de outros jovens cineastas como Angelina Vázquez, constituiu a Equipo Tercer Año.

O nome Tercer Año, que em princípio seria o título do seu futuro filme $A$ Batalha do Chile, contém a ideia de fazer uma crônica sobre o terceiro ano do governo de Allende. No entanto, em finais de 1972, a situação no Chile era de 
instabilidade. A crise de outubro orquestrada pela oposição - com a mobilização das organizações patronais, da classe média e juntamente com o boicote econômico norte americano -, provocou a paralização de vários setores importantes. Dessa maneira, com a impossibilidade de obter recursos, a empresa estatal Chile Films congela seus projetos e acaba demitindo Guzmán e seus companheiros de trabalho. Sem negativos e o suporte que a Chile Films proporcionava, Guzmán resolve escrever uma carta em 14 de novembro de 1972 para Chris Marker, na tentativa de obter ajuda. Sua carta exemplifica bem sua angústia diante do cenário político em que vivia e do filme que tinha em mente:

(...) Nossa situação política é confusa e o país está vivendo uma situação de préguerra civil, o que provoca tensão entre nós... A luta de classes se dá em todas as partes. Em cada fábrica, em cada propriedade camponesa, em cada povoado, os trabalhadores levantam a voz e exigem o controle em seus centros de trabalho... A burguesia utilizará todos seus recursos. Utilizará a legalidade burguesa. Usará suas próprias organizações trabalhistas com o apoio econômico de Nixon... Tem que se fazer um filme sobre tudo isso!...Uma reportagem ampla feita nas fábricas, campos, minas. Um filme de indagação onde os grandes cenários são as grandes cidades, os povos, a costa, o deserto. Filme composto de muitos capítulos, cujos protagonistas são o povo, seus dirigentes, por um lado, e a oligarquia, seus líderes e suas conexões com o governo de Washington, por outra. Filme de análise. Filme de massa e de indivíduos. Filme trepidante realizado a partir dos feitos diários, cuja duração final é imprevisível... Filme de forma livre, que utiliza a reportagem, o ensaio, a fotografia fixa, a estrutura dramática da ficção, o plano sequência, tudo utilizado segundo as circunstâncias, na medida em que a realidade se apresente. No entanto NÃO TEMOS material virgem. Devido ao bloqueio dos Estados Unidos, as importações podem demorar um ano. Para conseguir esse material temos pensado em você... Desculpe a extensão e peço que me responda com toda a franqueza. Confio plenamente em seu critério. Um abraço, Patricio (Guzmán, 2012.c [1972]: s/p).

Após uma semana, Guzmán recebe uma resposta de Marker em que dizia: "Farei o que puder. Abraços. Chris". No mês seguinte, chega ao aeroporto de Santiago uma caixa que vinha diretamente da fábrica Kodak (Rochester), contendo 15.000 pés de filme virgem Plus-X, 10.000 pés de 4-X, 10.000 pés de duplo $X$, mais uma reserva de 4.000 pés de Plus-X e 4.000 de 4-X além de 134 cintas magnéticas para o gravador Nagra. ${ }^{13}$

\footnotetext{
${ }^{13}$ A Batalha do Chile foi filmado com negativo $16 \mathrm{~mm}$. Para cada 1200 pés de filme, numa rodagem de 24 frames por segundo, o tempo gerado de filmagem é de 33 minutos e 20 segundos. Dessa forma, o que Guzmán e sua equipe tinham era um pouco mais de 20 horas de filme. Isso forçou o diretor criar um esquema de trabalho com o objetivo de organizar as principais ideias e lugares a serem registrados para que não houvesse nenhum desperdício de material virgem.
} 
Em fevereiro de 1973 se inicia as filmagens de A Batalha do Chile. Nos três minutos iniciais de créditos, ouve-se o som de caças voando intermitentemente quando uma explosão de bomba rompe o fundo preto dos letreiros e vê-se o pátio superior do palácio de La Moneda sendo bombardeado. Um plano próximo mostra a fumaça e as labaredas de fogo que saem das sacadas, com um corte para um plano aberto, passa-se a ver o palácio inteiro e o resultado do brutal ataque ouvido. É ainda sobre esta imagem que o subtítulo aparece: Primeira Parte: La Insurreción de La Burguesía.

A voz do narrador na sequência seguinte indica a volta ao tempo diegético que havia se estabelecido: "6 meses antes do bombardeiro de La Moneda, há eleições parlamentares. As forças políticas estão divididas em dois blocos. A centro-direita dos partidos Democrata Cristão e Nacional. A esquerda, reunida na Unidade Popular, que apoia Allende.” Guzmán começa pelo fim - um fim que todos já conhecem - para depois retornar ao começo e seguir os acontecimentos em ordem cronológica. Esse movimento de transgressão temporal está presente não só nessa primeira parte como também na estrutura de $A$ Batalha do Chile. De modo que a última parte da trilogia, $O$ poder popular, regressa no tempo histórico dos grandes acontecimentos para apresentar a forma como os trabalhadores da UP apoiados pela CUT (Central Única de Trabajadores de Chile) se organizaram nos cordões industriais na tentativa de combater a crise do país. Assim, em um primeiro nível, o filme se aproveita de uma ordem cronológica dos eventos, mas também utiliza uma filmagem capitulada, ou seja, apresenta alguns temas em separado para localizar melhor o espectador.

O abrupto corte temporal presente no começo do filme é também um corte político. Das imagens, que mostram a violência do golpe militar, o espectador regressa para o período do governo de Salvador Allende, nos dias que antecedem as eleições legislativas de março de 1973. A tensão política era grande. Caso a oposição garantisse dois terços das cadeiras do Legislativo, um pedido de impeachment seria feito, numa tentativa, ainda por vias legais, de depor o governo de Allende. Após o complicado ano de 1972, no qual uma forte ofensiva da oposição teve como resultado a paralisação quase que integral das atividades econômicas, o país estava dividido ao meio. O Chile vivia dificuldades com o crescente desabastecimento e a consequente escassez de produtos: o anúncio de um esquema de racionamento acirrou ainda mais os ânimos e o clima de 
polarização nas vésperas da eleição. Nesse cenário, o partido Democrata Cristão (DC) - que até então se propunha a ter um lugar de centro político e a estabelecer um diálogo com o governo - acreditava que obteria uma esmagadora derrota da UP, persistindo, como aponta Aggio, na estratégia "de transformar as eleições de março num plebiscito contra o governo" (1993:143).

Dessa forma, uma diversidade de opiniões aparecem no filme, numa construção dialética - uma estrutura que Patricio Guzmán busca em seu filme como um todo:

...utilizei o 'diálogo dos contrários', o contraponto real que havia entre a esquerda e a direita, ou os 'núcleos', que eram cenários privilegiados por onde passava toda a realidade, como o Parlamento, de onde se discutia os problemas do país (Guzmán in Ruffinelli, 2001 [1993]:338).

Dessa maneira, intercalam-se as opiniões pró-Allende e os discursos da oposição crescente, dos menos exaltados até os mais radicais, como vemos na fala de uma senhora: "Os comunistas nojentos têm de ir embora do Chile!". Essa cena, inclusive, será retomada em seu filme Chile, memória obstinada, de 1997, alertando que a radicalidade daquela fala apoio o golpe no passado e permanece forte no discurso da classe média do país.

Essa radicalidade, que, como vimos, culmina com o ataque aéreo ao Palácio de La Moneda, também está presente na sequência que encerra $L a$ insurrección de la burguesía e inicia El golpe de estado. Nela, as imagens não pertencem a Jorge Müller Silva (fotógrafo de A Batalha do Chile), mas de um jovem câmera argentino chamado Leonardo Henrichsen que, ao filmar a fracassada tentativa golpista de 29 de junho de 1973, acabou filmando sua própria morte $^{14}$. A sequência sugere também a própria morte do espectador - pois o espaço do documentário é também percebido como o mundo que o espectador vive, concreto e existente -, que, diante do soldado armado, após o disparo, junto com a câmera trêmula, como que também sucumbe. Fernão Ramos (2005) comenta essa sequência se valendo da noção do "olhar ameaçado" de Vivian Sobchack quando a segurança física é negada pela proximidade da morte ou do perigo:

\footnotetext{
${ }^{14}$ Patricio Guzmán narra no livro El cine contra el fascismo de Pedro Sempere (1977) que esse material fílmico foi recuperado por operários de esquerda que encontraram a câmera de Henrichsen caída, entregando à Chile Films (informação colhida na tese $O$ Chile na obra de Chirs Marker: um olhar para a Unidade Popular desde a França (2013), de Carolina Amaral de Aguiar).
} 
No caso do morte de Leonardo Henrichsen, o fim da presença de seu corpo, como sugeito que interage com a circunstância de sua morte, coincide com o fim da imagem, como expressão do sujeito-da-câmera. Essa é a integração plena, a maior possível, entre o sujeito e o sujeito-da-câmera, e ocorre no momento de intensidade máxima da imagem, o da figuração da morte" (Ramos, 2005: 206)

Interessante notar que essa sequência inalgura o trabalho de congelamento e recorte da imagem de Patricio Guzmán. Nela, o diretor frisa a imagem e cria molduras para direcionar o olhar do espectador. É importante notar que Chirs Marker, um dos colaborador de A Batalha do Chile, já na década de 60, utilizava muito a fotografia estática, além de desenhos e animações, em seu trabalho de montagem.
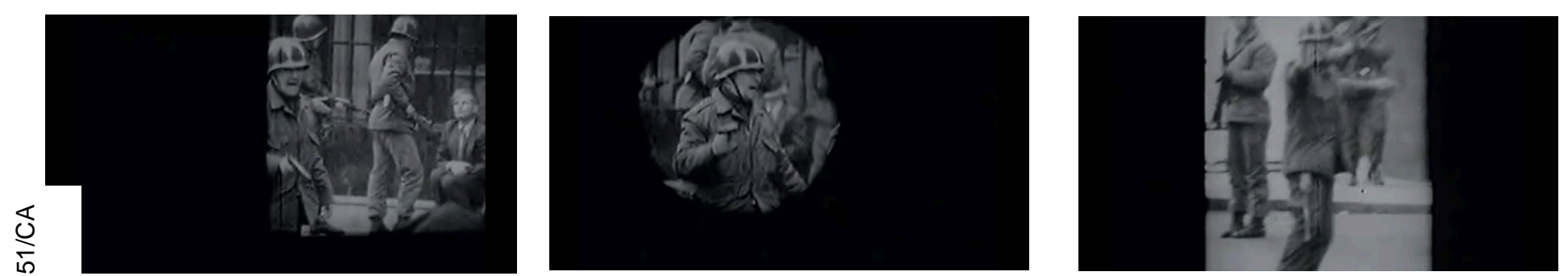

Figuras 01, 02 e 03: O congelamento da imagem e o trabalho de emolduramento.

O congelar dessa imagem é também a distensão do tempo, Guzmán reinterpreta essa imagem e elabora sua narrativa, o narrador diz: "Não só registra sua própria morte, como tambem registra, dois meses antes do golpe final, a verdadeira cara de um setor do exército chileno".

Essa forma de registrar o dia a dia, os pormenores ocultos de um determinado evento futuro, a escalada da violência, foi em A Batalha do Chile, como definiu o próprio diretor, a forma de captar os "feitos invisíveis". Como explica:

Quando se iniciava um conflito, uma greve, por exemplo, os canais de televisão filmavam tudo, mas nada filmavam do processo anterior: as reuniões sindicais que deram origem à greve, os problemas que desencadearam o conflito e seu seguimento posterior, que eram 'invisíveis' para os meios convencionais [...] Não me dispersei (como fiz na filmagem de El primer año), preferi seguir passo a passo uns acontecimentos selecionados e mostrá-los paulatinamente em forma detalhada, para assim capturar - em maior número - estes momentos 'invisíveis' (Guzmán in Ruffinelli, 2001 [1993]: 338-339 e 402).

Assim, ao conseguir desenvolver uma análise através desse "diálogo dos contrários", A Batalha do Chile contribui para a compreensão daqueles meses dramáticos que antecederam o golpe militar. Além desses discursos captados pela 
câmera e pelo gravador de som, existe uma outra narrativa que se criou durante o processo de montagem do filme em Cuba. A voz em off de Abilio Fernández tinha, de acordo com Guzmán, a função de ser "um texto simples - seco e breve -, que abarca dados e informações que ajudam a compreender melhor o filme" (Ibidem: 402). No entanto, em 1993, Guzmán resolve fazer algumas alterações no texto do narrador. Dessa maneira, já com uma perspectiva retrospectiva da história, ele compreende que seu texto era excessivamente ideologizado. Assim, Guzmán modifica algumas palavras - no lugar de "imperialismo" se ouve hoje "governo norte-americano" ou "governo de Washington, em vez de "partidos burgueses" é usado "partidos da oposição", a utilização da palavra "fascismo" foi moderada e trocada em certos momentos por "extrema direita".

Ainda que se trate da mudança de um número limitado de palavras, essas alterações mostram a preocupação do diretor com a história de seu país e a memória que busca promover e manter viva.

Ao modificar ligeiramente a voz em off, a obra volta a capturar espectadores mais jovens (menos politizados que nós e que utilizam outros estereótipos). Assim a película volta a "abrir-se", a suscitar interesse em outros públicos, ao menos momentaneamente" (ibidem).

A revisão feita por Guzmán de seu filme $A$ Batalha do Chile é sua busca por novas maneiras de se trabalhar a realidade. Como ele mesmo comenta: “... as narrações que nos pareciam naturais em 1950 hoje em dia nos parecem carregadas e demasiadas pedagógicas" (Guzmán in Ruffinelli, 2001 [1996]: 345). Em seus anos como exilado (1973-1996), Guzmán realizou filmes como La rosa de los ventos (1982), seu primeiro e único filme de ficção, no qual utiliza uma estrutura que lhe permite eliminar os tempos históricos - uma estrutura muito presente na construção narrativa La Cruz del Sur (1992). Sobre a prática documental de Guzmán, há que se indicar também que ele filmou En nombre de Dios (1986) na clandestinidade, durante a ditadura de Pinochet. Um outro aspecto de seu trabalho é ter realizado também duas séries para TV: Un documental sobre México precolombino (1987) e El proyecto ilustrado de Carlos III (1988). Depois, portanto, de duas décadas de trabalho documental e, como mencionado, de exercício ficcional e estético em La rosa de los ventos, é na década de 90 que, como identifica o crítico uruguaio Jorge Ruffinelli, seus filmes ganham uma carga particularmente mais criativa e pessoal: "La Cruz del Sur primeiro e, em especial, 
Pueblo en vilo (1996) demonstram a plenitude de seu talento e do melhor momento de sua maturidade criativa" (Ruffinelli, 2001:267).

Esse novo projeto pessoal de documentário, onde se inicia a utilização de sua própria voz na narração, ganha contornos ainda mais interessantes em Chile, memória obstinada (1997), quando, retornando a Santiago, agora com um presidente eleito no país, traz consigo os rolos de A Batalha do Chile para exibilos, interagindo com pessoas de diferentes camadas sociais e, assim, colocando em pauta a ausência do trabalho de memória sobre os anos de Salvador Allende. 
2.

Chile, memória obstinada, uma ponte por cima da ruptura

O passado traz consigo um índice misterioso, que o impele à redenção. Pois não somos tocados por um sopro do ar que foi respirado antes? Não existem, nas vozes que escutamos, ecos de vozes que emudeceram?

(Walter Benjamin)

A partir dos anos 1990, há uma intensificação do trabalho de Guzmán, no que diz respeito a uma perspectiva pessoal na construção da memória histórica, um trabalho que, cada vez mais, se associa à sua experiência individual de vida, bem como do próprio processo de construção fílmica. Em Chile, memória obstinada (1997), vemos o sujeito (o diretor) realizar um "efeito de leitura" onde ele se apresenta como dois protagonistas: "o sujeito detrás da câmera, e aquele diante do texto. A densidade discursiva está a serviço do duplo vínculo afetivo com a imagem em movimento" (Molfetta, 2002:75). A "leitura" se dá, então, por uma fronteira menos fixa do lugar do diretor no espaço que participa, a subjetividade se apresenta como um fator construtivo do filme. Como observa Guzmán:

Um certo olhar reflexivo nasceu nesses últimos 10 anos, dentro do cinema documental europeu e de outro países. Apareceu uma certa lentidão contemplativa que não completava os espaços "vazios" com ações, nem com música e nem com viradas narrativas. Assim começou a surgir uma linguagem dúbia, com imprecisões, com inseguranças, com silêncios e com vozes em off cada vez mais íntimas. Me vem à memória algumas sequências de Richard Dindo, de Robert Kramer e de muitos outros que começaram a misturar, não a "ficção" com o "documental", mas seu próprio eu com a realidade que estava filmando, convertendo eles mesmo em personagens "literários" de seus filmes (Guzmán, in Ruffinelli 1993: 349).

Uma das primeiras mudanças da virada subjetiva em relação a seus outros filmes é a transformação do narrador. Temos em A Batalha do Chile uma voz em over impessoal e anônima que relata os fatos de um modo distanciado. A autoridade que incorpora essa voz, segundo Mary Ann Doane, é o fato de ela estar descorporalizada em meio aos corpos do espaço diegético do filme, conferindolhe a capacidade de "interpretar a imagem, produzindo a verdade dela." (Doane, 2003:467). No entanto, essa verdade pode ter um custo - isso fica claro, como já mencionado, quando Guzmán reedita posteriormente a narração de A Batalha do Chile para substituir algumas palavras com teores explicitamente ideológicos 
daquela época -, pode estar "contaminada" pelo enunciado, como chama atenção Serge Daney: "A voz off que força a imagem, que intimida o olhar, que cria a dupla dificuldade, é um dos modos privilegiados da propaganda no cinema." (Daney, 2007:80). Em A Batalha do Chile a voz do narrador está tanto geograficamente como temporalmente distante da imagem filmada: pode-se ouvilo no filme, mas nunca vê-lo ou senti-lo em sua forma objetiva e direta de se reportar ao espectador. Nessa abordagem, o filme estaria dentro do modo expositivo que Nichols define. Em suas três partes, o documentário oferece um relato histórico sustentado pela voz em over e na organização dos eventos por cartelas que garantem a progressão da história. As entrevistas estão montadas de forma a confirmar as imagens e o discurso que a voz do narrador profere. Segundo Nichols:

O modo expositivo enfatiza a impressão de objetividade e argumento bem embasado. O comentário com voz-over parece literalmente "acima" da disputa; ele tem a capacidade de julgar ações no mundo histórico sem se envolver nelas. (...) O documentário expositivo é o modo ideal para transmitir informações ou mobilizar apoio dentro de uma estrutura preexistente ao filme." (Nichols, 2005:114)

Em Chile, memória obstinada, a pretensão de objetividade e da não intervenção diante do registrado estão anulados desde o começo do filme. Aqui, além de ceder a voz aos entrevistados, é o realizador que toma para si a função do narrador. Esse expediente surge em seu filme Pueblo en Vilo (1995) sobre uma pequena cidade onde viveu o escritor mexicano Luis Gonzáles, que ficou conhecido pelo livro que escreveu sobre ela, Pueblo en Vilo: Microhistoria de San José de Gracia.

Ainda que em El primer año, La respuesta de Octubre e A Batalha do Chile a equipe de filmagem (incluindo o próprio diretor) aparecem várias vezes nos planos e, as vezes, se escuta a voz de Guzmán dirigindo as perguntas, pela primeira vez em Pueblo en Vilo Guzmán assume o relato completo em sua voz (Ruffinelli, 2001:272-273).

O estilo distanciado da narração em terceira pessoa cede lugar ao relato pessoal. Essa modalidade performática faz com que o espectador não fique simplesmente diante de um comentário sobre o mundo histórico que flui, mas que é captado pela experiência vivida pelo diretor dentro desse mesmo mundo histórico que, afinal, ele compartilha - tanto com os personagens quanto com o 
próprio espectador. $\mathrm{O}$ relato em primeira pessoa também situa temporalmente o diretor no próprio processo de realização, o que, inevitavelmente, confere novos dados ao filme.

Bill Nichols identifica - através de uma análise de "modos" de representação no documentário - uma linha evolutiva da ética no filme dito de não-ficção e que em parte vem desembocando no modo "reflexivo" ou, como ele aponta, em sua versão mais contemporânea: o modo "performático". Portanto, são essas novas estratégias reflexivas que "questionam o ato de representação e abalam a suposição de que o documentário se funda na capacidade do filme de capturar a realidade" (Nichols, 2005:51). O modo performático é aquele onde o cineasta é, por assim dizer, mais palpável, fisicamente presente. Existe nele um aparente esforço para expressar seus sentimentos e visões de mundo. Assim, o diretor enfatiza o aspecto subjetivo e expressivo de seu próprio engajamento com o tema proposto e a receptividade do público a esse engajamento. Para Fernão Ramos, os valores que orientam esse tipo de documentário está relacionada ao que ele chama de ética modesta. Com a queda do Muro de Berlim, o desmonte dos governos socialistas e, consequentemente, com o descrédito pelas grandes ideologias - que marcaram muito o cinema latino-americano -, vemos, ao longo da década de 90, que "o sujeito-da-câmera em seu embate com o mundo, caracteriza-se pela valoração da posição modesta, de onde espalha seu olhar crítico pelo horizonte que lhe cerca" (Ramos, 2008:38). O sujeito modesto não vislumbra a imparcialidade; antes, ele enuncia sua condição própria e tem "como alvo questões sociais pontuais que envolvem seu ego, longe de tematizações mais amplas sobre a sociedade contemporânea" (Ibidem:39). Jean Claude Bernadet, em um artigo do livro O Cinema do Real, observa, dentro desse cenário mais contemporâneo do cinema documentário, um tipo de processo de trabalho cinematográfico que ele chama de "documentário de busca". O autor comenta os filmes 33 (2003), de Kiko Goifman e Passaporte Húngaro (2003), de Sandra Kogut, o primeiro consiste na busca do diretor por sua mãe biológica enquanto o segundo, na tentativa de Kogut, descendente de húngaros, de conseguir a nacionalidade e o passaporte húngaro. Chile, memória obstinada (1997) é também uma "busca": aqui Guzmán retorna a Santiago para encontrar personagens que conheceu e filmou no passado. Todos esses filmes são "projetos que partem de um alvo bastante preciso, bastante determinado, mas os cineastas não sabem de que 
forma será atingido. Portanto, a filmagem tende a se tornar a documentação do processo" (Bernadet, 2005:144).

Esse processo de construção, com sua imprevisibilidade e incertezas sobre o que se encontrará pelo caminho, constitui um projeto bastante pessoal, também chamado, como já mencionamos, de performático. Nichols ainda acrescenta sobre o modo performático: "Todos os filmes desse modo compartilham características com filmes experimentais, pessoais e de vanguarda, mas com uma ênfase vigorosa no impacto emocional e social sobre o público" (Nichols, 2005:62-63).

Esse caráter de ênfase social parece claro no trabalho de Guzmán como documentarista. Mais recentemente, desde que regressou ao país para filmar, seus temas de trabalho partem sempre da mesma motivação, mesmo que essa motivação seja ampla e não tenha contornos rígidos: a motivação de trabalhar, junto com as novas gerações chilenas, a memória marginalizada dos tempos de ditadura, bem como problematizar o processo de democratização do Chile dos anos 90, juntamente com a preocupação de resgatar e provocar as memória individuais (tanto suas quanto dos personagens que ele encontra) para a esfera pública. 


\section{1}

\section{A memória como preocupação histórica}

Chile, memória obstinada (1997) pode ser visto como uma continuação de sua monumental trilogia A Batalha do Chile (1975-9). Na década de 1990, mais de 20 anos depois de partir, o chileno Patricio Guzmán retorna a seu país não mais na condição de exilado. De fato, Guzmán já havia voltado 10 anos antes - entre março e maio de 1986 - para filmar, de forma clandestina, seu filme En nombre de Dios, um documentário sobre o papel da Igreja Católica contra o regime de Pinochet.

A premissa inicial de Chile, memória obstinada é (re)encontrar os personagens anônimos que apareciam em A Batalha do Chile. No documentário, além do interesse pelas pessoas e memórias de quem viveu o período do governo de Salvador Allende, a atenção também recai nas gerações mais novas, confrontando-as com as imagens de seu antigo filme, que, até pouco tempo, só podia ser visto clandestinamente.

O título do filme - Chile, memória obstinada - já anuncia a condição de uma memória que persiste, que não pode ceder à obliteração dela por parte de práticas e instituições herdadas da ditadura ou, apesar do processo democrático, ainda persistentes. Existe nessa memória obstinada, por parte de Patricio Guzmán, um chamado à questão do dever de memória, isto é, o dever de não esquecer, o dever de ir contra uma história criminosa que, se estabelecida como história oficial conivente com a ocultação dos crimes, também suprimirá o clamor por justiça. A ideia do rastro, presente no trabalho do filósofo alemão Walter Benjamin, que voltaremos a discutir no próximo capítulo, é particularmente importante no trabalho de Guzmán, pois será através de rastros que muitas vezes se fará possível a evocação do dever de memória. "O que a noção de rastro e esquecimento têm em comum é, antes de tudo o mais, a noção de apagamento, de destruição." (Ricoeur, $2003, \mathrm{~s} / \mathrm{p})^{15}$. O esquecimento, portanto, caminha lado a lado com o processo de rememoração, "essa busca para reencontrar as memórias perdidas, que, embora

\footnotetext{
${ }^{15}$ RICOUER, Paul. Conferência escrita e proferida em inglês em 8 de Março de 2003 em Budapeste sob o título "Memory, history, oblivion" no âmbito de uma conferência internacional intitulada "Haunting Memories? History in Europe after Authoritarianism", versão online em português disponível em http://www.uc.pt/fluc/lif/publicacoes/textos_disponiveis_online/pdf/memoria_historia (acessado em $4 / 11 / 13)$.
} 
tornadas indisponíveis, não estão realmente desaparecidas" (ibidem). Chile, memória obstinada é uma espécie de portal que confronta o presente chileno na sua tentativa de "reconciliação" nacional com o passado avassalador. O filme possui diversos métodos para ativar a memória do período da ditadura, mas, como já mencionado, o principal recurso - que é de certa forma a linha metodológica e formal para que o filme exista - é seu próprio documentário A Batalha do Chile: 23 anos depois, Guzmán retorna ao Chile para encontrar e exibir o filme às pessoas que fizeram parte da época de sua filmagem em 1973, que, nele, estão presentes, ainda que brevemente. "Agora me parece fácil. Mas, no começo das filmagens, não sabia onde me colocar. Sentia o Chile com muita intensidade. A proximidade com o país me inibia. (...) O que me ajudou muito foi encontrar os distintos personagens do filme" (Guzmán, 1993: s/p).

Essa sua viagem ao Chile é também uma viagem no tempo - "o cineasta não viajou somente de um ponto geográfico (Paris) para outro (Chile), ele também se transformou em um viajante do tempo" (Rodríguez, 2007:15).

Assim, ao sair do presente em direção ao passado, Guzmán não segue uma linearidade cronológica em sua construção histórica. A sobreposição de temporalidades é uma constante no filme. Logo na sequência de abertura, antes mesmo de qualquer imagem aparecer, vemos os primeiros créditos: o título do filme, seguido pelos nomes de Patricio Guzmán e dos produtores e, por fim, uma dedicatória a suas duas filhas, Andrea e Camila. Durante essa sequência ouvimos o som do trânsito de carros na cidade atual e, após duas buzinadas, um curto silêncio se instaura enquanto lemos a nota dedicatória para as filhas. O breve silêncio, como se estivéssemos no olho do furacão, é brutalmente interrompido pelo som de um caça. Em seguida, a primeira imagem do filme surge, o som da cidade e dos carros que antecederam o silêncio dão lugar à imagem em preto e branco desse caça e seu barulho cortante. Voltamos para o dia do golpe, em 1973. O Palácio de La Moneda está em chamas. A regressão às imagens desse evento traumático é a volta também para as últimas memórias do diretor em seu país, antes de se exilar. Dessa maneira, Guzmán, já no início, ilustra e se apropria de uma atitude que Walter Benjamin chamou de "materialismo histórico", isto é, de uma história que se volta para as classes que foram oprimidas pelas vitórias de uma classe dominante na qual a historiografia insiste em perpetuar esse passado do "vencedor" : 
Articular historicamente o passado não significa conhecê-lo "como ele de fato foi". Significa apropriar-se de uma reminiscência, tal como relampeja no momento de perigo. Cabe ao materialismo histórico fixar uma imagem do passado, como ela se apresenta, no momento do perigo, ao sujeito histórico, sem que ele tenha consciência disso (Benjamin, 1987:224).

O golpe militar é esse "momento de perigo", um momento em que sua própria vida esteve em risco e que Guzmán não quer esquecer. Naquele dia, as chamas não só queimaram o palácio, mas calcinaram o sonho de muitos chilenos: agora as cinzas, varridas para longe da história oficial, precisam ser reunidas e revivificadas em novas narrativas.

Assim, o filme busca tornar "visível os lugares de memória excluídos dentro das esferas públicas da pós-ditadura", fazendo o passado ser reconhecido pelas reminiscências desses locais (Gómez-Barris, 2009:105). Esse argumento de Macarena Gómez-Barris é útil para pensar a forma como Guzmán vai estreitar os laços de sua memória e dos eventos da década de 70 com os espaços atuais e representativos do centro cívico de Santiago.

O ponto de partida é o bombardeio do Palácio de La Moneda. Uma imagem que marca o início de $A$ Batalha do Chile e volta a se repetir, agora como uma imagem de arquivo, em Chile, memória obstinada. A escolha pelo Palácio é clara: além de ser a casa de governo, ele concentrou ao seu redor os vários movimentos da Unidade Popular, sendo bombardeado por caças e, por fim, invadido pelos militares em 11 de setembro de 1973, provocando a morte de Salvador Allende. Em contraste com as imagens dos bombardeios que vemos no início do filme, um corte temporal apresenta o palácio reformado, sem fissuras, sem marcas de tiros em seu concreto. Não há pistas aparentes que possam levar a uma reflexão sobre o legado da ditadura. É assim que Guzmán constrói narrativamente seu dever de memória - não devemos esquecer o que está por trás da tinta branca e do dia ensolarado. É, portanto, a um movimento de ressemantização desses locais públicos que leva seu ato de filmar. Cabe retomar aqui uma outra frase de Benjamin: "Nunca houve um monumento de cultura que também não fosse um monumento da barbárie" (Benjamin, 1987:225). O diretor está enfatizando que a barbárie permanece, mesmo que de outra forma, na sociedade chilena. Enquanto a sequência do bombardeio, retirada de seu filme $A$ Batalha do Chile, expõe as últimas consequências da ação militar contra o governo 
democrático de Salvador Allende, a cena atual (1996) do Palácio de La Moneda em Chile, memória obstinada, por sua vez, ao mostrar os soldados marchando para dentro de sua porta frontal, problematiza a continuidade da participação militar no governo de transição democrática.
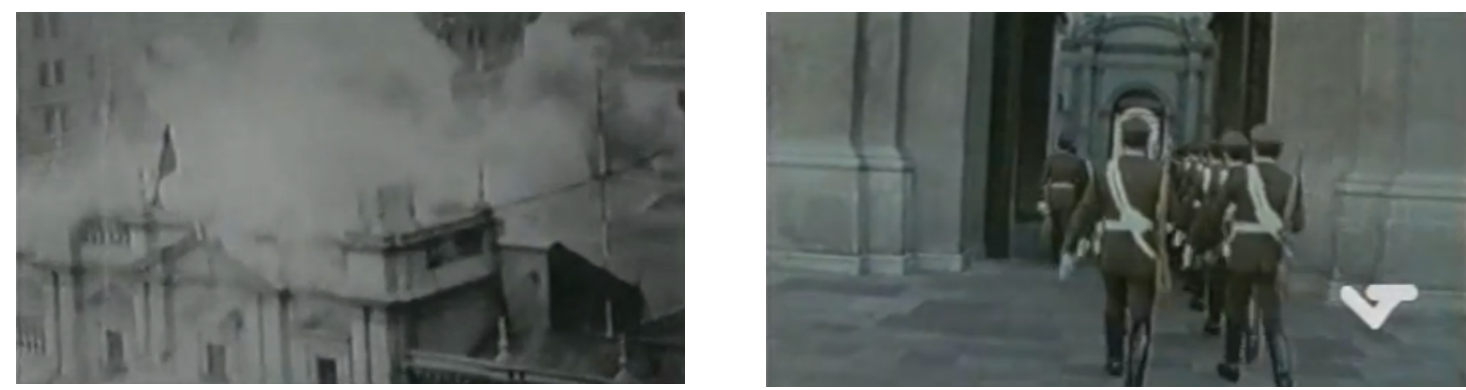

Figuras 04 e 05: O palácio em chamas em 1973 e os soldados no mesmo local em 1996.

Após a elipse temporal, Guzmán acompanha a visita de Juan, ex-segurança pessoal de Allende, ao já reformado Palácio de La Moneda. O confronto de Juan com o espaço e as memórias que Guzmán suscita em seu personagem ao inseri-lo, anos depois, nesse local são, em última instância, uma provocação consigo mesmo. Ele narra: "Igual a mim é a primeira vez em 23 anos que ele volta a esse lugar"; sua voz serve para ancorar no presente uma camada pessoal do passado. Não se trata mais de mostrar a realidade, mas sim de convidar a pensar, junto com o realizador, como reconstruir o passado e suas memórias através dos vestígios no presente. O testemunho de Juan se dá enquanto ele e Guzmán caminham pelas salas e corredores do palácio. A lembrança de Juan seria, como Maurice Halbwachs indicou em seu estudo sobre a memória coletiva, "uma imagem engajada em outras imagens" (Halbwachs, 2004: 76); sua reconstrução do passado é suscitada e compartilhada no ato da filmagem, "com ajuda dos dados emprestados do presente..." (Ibidem: 75). O que Halbwachs enfatiza é que as lembranças do passado, por mais sentimentais e atreladas a experiências pessoais que sejam, só existem a partir dos quadros sociais em que vivemos. Assim, o passado que existe no presente é o passado que existe na consciência de um grupo. E será o passado frágil e pouco revisitado do período militar que Chile, memória obstinada não quer deixar esmorecer.

Os testemunhos, as imagens, os relatos de Guzmán e sua experiência de investigação serão as marcas que assinalam um caminho possível para reviver a história chilena dos tempos da Unidade Popular e de todo o passado negado que 
caminha pouco a pouco para o esquecimento. O filme restitui uma densidade histórica ao Palácio, "fazendo uma arqueologia fílmica" que revela o que a reforma do edifício oculta (Sadek, 2013: 34).

Ao ceder espaço ao real - inscrição verdadeira -, o filme reconhece e combate esse presente. A câmera filma o embate dos corpos: o de Juan que caminha com um tripé de câmera em mãos e o de Guzmán que o interpela. Dessa forma, "o encontro entre um corpo e uma câmera é um acontecimento singular, irreversível, incomparável e não reprodutível. Nenhuma mise-en-scène jamais abolirá o acaso ligado à inscrição verdadeira" (Comolli, 2008:240). Aqui reside a força do cinema documentário ao estar sob o risco do real que Jean Comolli indica:

O cinema, na sua versão documentário, traz de volta o real como aquilo que, filmado, não é totalmente filmável, excesso ou falta, transbordamento ou limite lacunas ou contornos que logo nos são dados para que os sintamos, os experimentemos, os pensemos (Comolli, 2008:177).

As lacunas sempre existirão. A memória combate o esquecimento, indo contra o pesadelo de uma amnésia coletiva, vendo-se, ela própria, em um processo seletivo de reconstrução do passado. Tanto as imagens, quanto a memória que ela evoca, são seletivas, abrindo espaços e esbarrando em pontos cegos, levando a que pensemos a impossibilidade de olhar para o passado. Nesse limite, ao viver no presente, Guzmán se torna um investigador. Nesse filme-investigação, ele explora o passado com os indícios no presente. $\mathrm{O}$ autor francês Guy Gauthier reforça o que foi dito: "o documentário refina a arte das relações entre o presente e a memória, torna-se exploração sentimental do passado e instrumento para o conhecimento histórico" (Gauthier, 2011:246).

Como método de exploração desse presente - pois quem filma, filma sempre no presente -, a montagem será fundamental para que a dimensão história seja vista e suscitada; é através dela que Guzmán intensifica as lacunas e a possibilidade de sensibilizar o espectador, convidando-o a pensar.

A noção de imagem-lacuna, presente no livro Imagens Apesar de Tudo, de Didi-Huberman, é outra referência interessante para vermos como a imagem de arquivo opera na sobreposição entre o passado e o presente e, ainda, na possibilidade de experimentar o inimaginável. Para o autor, o documento de arquivo nunca permite que vejamos as coisas em "absoluto", a montagem se torna 
importante para construir seu sentido e, assim, o conhecimento histórico a partir das relações com outros elementos, com outras imagens, que podem vir de vários tempos heterogêneos para a construção da historicidade.

A montagem será precisamente uma das respostas fundamentais para esse problema da construção da historicidade. Porque não está orientado simplesmente, a montagem escapa das teleologias, faz visível os vestígios, os anacronismos, os encontros de temporalidades, cada pessoa, cada gesto. Então, o historiador renuncia de contar "uma história" mas, ao fazê-lo, consegue mostra que a história só é possível com todas as complexidades do tempo, todas as camadas da arqueologia, todos os pontilhados do destino (Didi-Huberman, $2007: \mathrm{s} / \mathrm{p}){ }^{16}$

Esse encontro de temporalidades já pode ser visto no filme de Gusmán feito para o canal TVE, La Cruz del Sur (1992), onde transitamos entre as épocas dos conquistadores no século XVI e as crenças religiosas atuais em países como México, Brasil, Equador e Peru.

Anos depois, em Chile, memória obstinada, ao montar os discursos dos testemunhos com as imagens de arquivo - sejam imagens em movimento de seu filme antigo sejam fotografias que ele examinará junto a seus personagens - ele evita que o tempo presente siga seu caminho linear, na crença de que a história, supostamente, se encaminha para uma emancipação dos sujeitos e em progresso constante.

"Aqui nesse lugar houve um movimento de massa impressionante, que pudemos filmar ao longo de um ano, às vezes, sem saber muito bem o que fazíamos." Essa narração acompanha o movimento de câmera que começa mostrando a praça em frente ao palácio e vem descendo até vermos a sacada e seu alambrado, que possui um formato espiralado, que nos remete à figura de um pião - de um movimento que gira em seu eixo e sempre volta ao mesmo ponto de partida (fig. 03). Um corte. O mesmo movimento se repete, mas a praça vazia dá lugar à uma multidão eufórica da UP (fig. 04). Em seguida, outro corte nos transporta novamente à praça vazia - uma tabula rasa do que um dia foi um intenso momento histórico (fig. 05). Pouco depois ouvimos a narração: "Para muitos o tema da memória é um tema encerrado."

\footnotetext{
${ }^{16}$ Cuando las imagens tocan lo real foi um texto lido por Didi-Huberman no curso realizado no Circuito de Bellas Artes de Madrid (CBA) em 2007.
} 

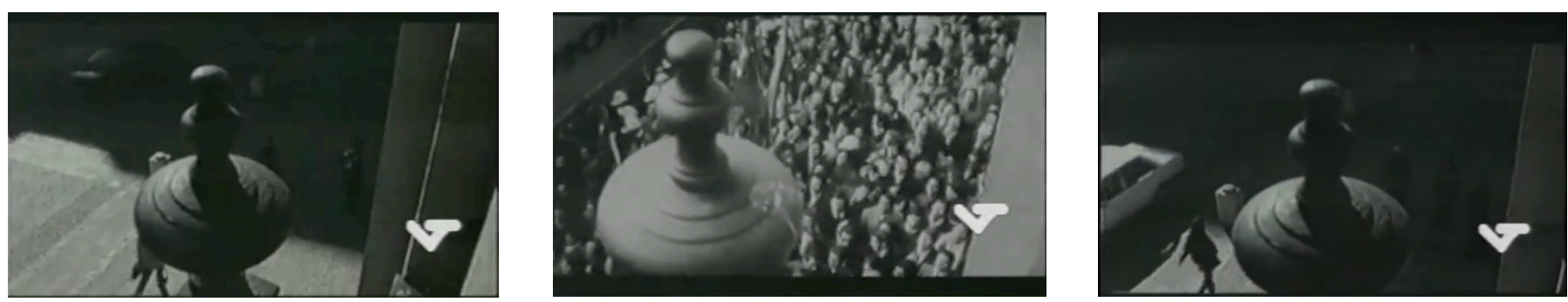

Figuras 06, 07 e 08: Fotogramas da sequência da sacada do Palácio de La Moneda.

O filme propõe a abertura da memória e de sua relação com a História. A ditadura de Pinochet, assim como os outros "eventos traumáticos" que marcaram o século XX, se inserem no contexto dos debates teóricos sobre a História do Tempo Presente. Sem entrar aqui na ampla discussão historiográfica sobre a validade do estudo do tempo presente e do desenvolvimento da valorização dos testemunhos diretos, bem como suas formas metodológicas, o que vale destacar é essa atenção particular para entender as possibilidades de um conhecimento histórico pelo confronto dos testemunhos de quem viveu ${ }^{17}$. Carlos Fico ainda acrescenta: "De fato, a marca central da História do Tempo Presente - sua imbricação com a política - decorre da circunstância de estarmos, sujeito e objeto, mergulhados em uma mesma temporalidade, que, por assim dizer, "não terminou” (2012:45).

Essa forma de retomar a história - e da realização de obras como um documentário - é, por natureza, o estudo e o contato, coexistente pelo historiador e testemunho, de um determinado contexto histórico. É assim que Guzmán se lança à frente da câmera e se coloca como peça importante nas relações afetivas que o filme cria. O testemunho direto é central para articular as temporalidades.

Além da confluência entre o personagem que filma e o diretor como personagem, uma marca dessa performatização do diretor dentro do documentário, outro indicador que aproxima narrador e realizador está presente na própria escolha dos entrevistados, dos testemunhos a serem colhidos. É o caso de seu tio Ignacio Vaenzuela e de seu amigo Ernesto Malbrán. Essa relação extremamente pessoal com os entrevistados faz com que eles estabeleçam uma conversação íntima mais do que um intercâmbio de perguntas e respostas. Esse procedimento

\footnotetext{
${ }^{17}$ Sobre o surgimento e implicações do estudo da História do Tempo Presente, ver FERREIRA, M.F. História, tempo presente e história oral, em Topoi, Rio de Janeiro, dezembro 2002, pp. 314332. e HOBSWAWN, Eric J. O presente como história: escrever a história de seu próprio tempo em Novos Estudos CEBRAP, no 43 , novembro de 1995, pp. 103-112.
} 
fica claro quando, por exemplo, fala com Álvaro Undurraga, médico e amigo, no qual relata sua passagem pelo Estadio Nacional que se converteu, logo após o golpe, em centro de detenção e tortura. Undurraga relembra seu encontro com Guzmán e este lhe pergunta sobre si mesmo: “Estava eu muito assustado?”. Essa relação íntima entre o realizador com os entrevistados sustenta e se solidariza com uma espécie de voz coletiva. É como se o filme se apresentasse como a voz de um "nós", o realizador se inclui ao incluir os espaços e pessoas que ele convoca. Aqui o discurso que prevalece é "Nós falamos sobre nós para nós" em vez da antiga tríade assinalada por Nicholls "Eu falo deles para você” (Nichols, 2005:173).

\begin{abstract}
Antes, nos contentávamos simplesmente com a entrevista em si, como em um jornal, mas não é assim, tem que passar um dia inteiro com um personagem, em um dado momento se cruza uma barreira invisível e já não é uma entrevista, é uma confissão, uma revelação, é uma sequência... (Guzmán in Celis, 2010 [2006]:260).
\end{abstract}

Dessa maneira, a voz do narrador, nesse relato, perde sua aura de autoridade central: esse esvaziamento da voz se preenche com um relato de vozes subjetivas e individuais com um forte sentido de comunidade e da memória deste grupo reprimido.

\title{
2.2
}

\section{Álbum de fotografias}

Podemos observar na famosa frase de Guzmán: "um país sem documentários é como uma família sem álbum de fotografias"18, o papel central que o diretor direciona à fotografia. Tanto que seu primeiro filme Electroshow (1966) é todo realizado a partir de fotos fixas, algo semelhante à forma narrativa utilizada por Chris Marker em La Jetée (1962), ainda que nessa época Guzmán não tivesse contato com o filme. Para Guzmán, a fotografia "É um campo ilimitado: sem mover-se para nenhuma parte, pode-se viajar pelo interior de uma

\footnotetext{
${ }^{18}$ Esta frase está inclusive estampada na página inicial de seu site: www.patricioguzman.com
} 
fotografia de uma maneira magistral" (Guzmán, 2010:263). Essa viagem é possível porque ela se torna o próprio objeto da rememoração. A foto capta algo secreto e efêmero, mas que é capaz de produzir significação. Assim como os rastros (marcas e materiais remanescentes do passado), a fotografia também precisa ser codificada - o acervo pessoal fotográfico que aparece no filme é um componente histórico, pois aquilo que restou é significativo para interpretar o que passou: "A fotografia é o resto de um momento do tempo e, como tal, ela é uma cifra; o que ela diz sobre o que ocorreu é uma imagem mínima, uma miragem, que precisa ser interpretada" (Ginzburg, 2012.a:114).

No caso de Chile, memória obstinada será a imagem fixa muitas vezes a via possível para que o discurso sobreviva; uma plataforma comum onde o trauma e as lembranças boas de uma época possam ser compartilhadas. De fato, a fotografia seria o meio primário para a transmissão transgeracional do trauma (Hirsch, 2008). Marianne Hirsh cunha o termo pós-memória para descrever a relação da geração posterior (filhos de sobreviventes) que cresceram sob as narrativas de seus familiares. As pós-memórias são, portanto, temporalmente e qualitivamente diferentes das memória dos sobreviventes. Para Hirsch, a força da pós-memória estaria justamente no fato de que a relação delas com o objeto é mediado não pela recordação direta, mas através de representações, projeções e da criação - “ muitas vezes mais baseado no silêncio do que no discurso, no invisível do que no visível" (2001: 220).

É, por exemplo, a partir das fotos da retirada dos últimos companheiros de Allende do Palácio de La Moneda que o pintor José Balmes irá recriar em sua obra os gestos brutais do dia 11 de setembro. Assim como sua pintura, o documentário se torna um mecanismo importante para desenvolver uma pós-memória nas gerações que cresceram na violenta sombra da ditadura. 

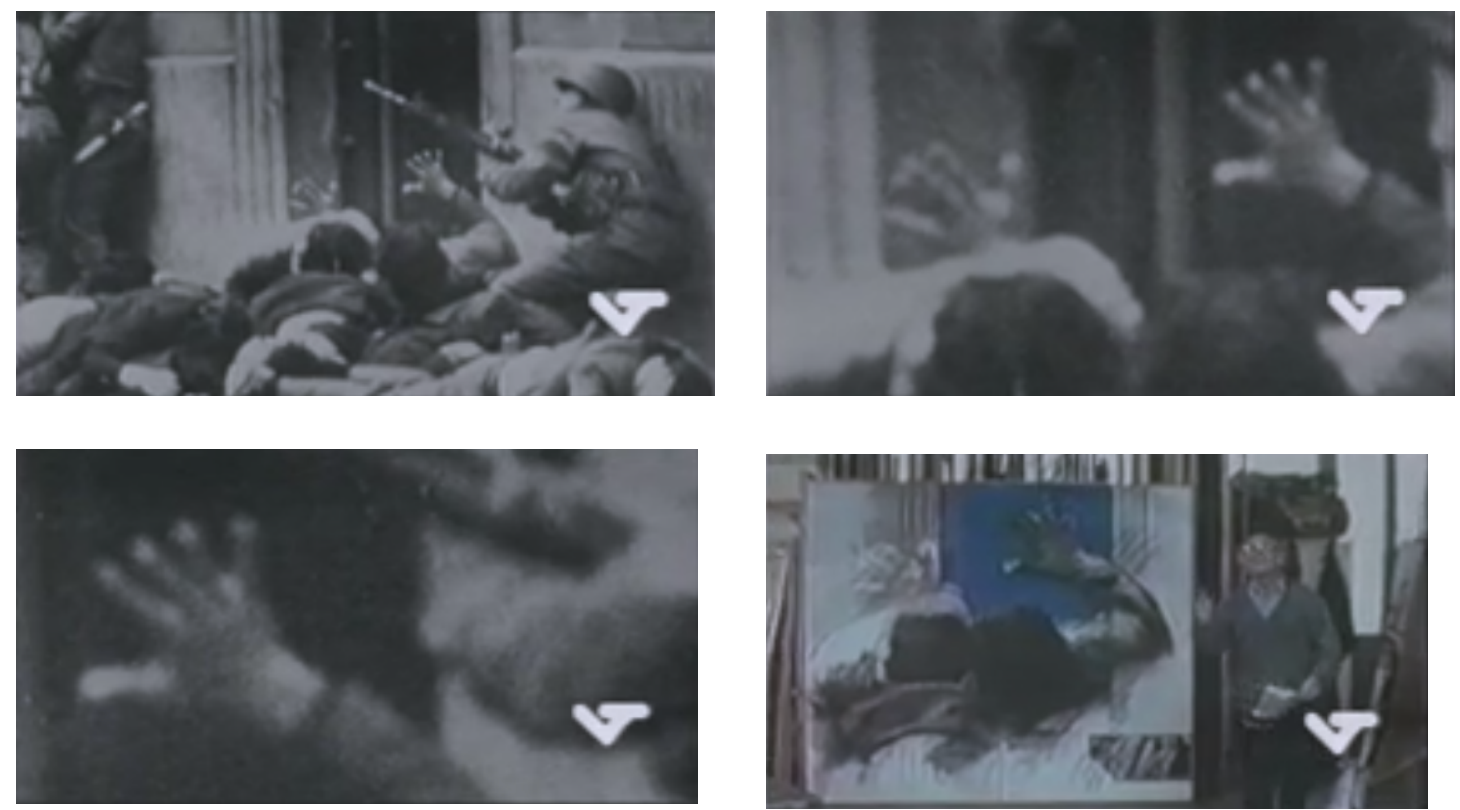

Figuras 09, 10, 11 e 12: a utilização da fotografia na sequência do pintor Balmes.

As "imagens nos permitem "imaginar" o passado de forma mais vívida." (Burke, 2004:17). A tese geral de Peter Burke em seu livro Testemunha Ocular é que as imagens (fotográfica e pictórica), assim como textos e testemunhos orais, são formas importantes de evidência histórica. Uma tese que Guzmán, ao colocar em prática seu modus operandi cinematográfico, parece defender.

Se, por um lado, nós somos a memória que temos, tudo aquilo que lembramos; por outro lado, a memória não é exclusivamente pensamento, imaginação e nossa construção social, mas também "uma determinada experiência de vida capaz de transformar outras experiências, a partir de resíduos deixados anteriormente" (Santos, 2003: 25-26), ou seja, a memória é um resultado de si mesma, que excede o escopo da mente humana e se objetiva em representações das mais diversas, como, por exemplo, a imagem fotográfica.

A pessoa que tirou a foto original não teve o controle sobre sua composição e muito menos sobre os gestos dos corpos em queda que registrou. Também desconhecia as consequências do que, enquanto testemunha, e, por assim dizer, apenas enquanto um guardião do momento captado, estava ainda por acontecer no Chile. Depois, o pintor, que não estava naquele dia em frente ao Palácio de La Moneda, pôde olhar a fotografia e assim "imaginar" aquele contexto. Sua pintura é um trabalho de reflexão e de sensibilização: ela chama atenção para o gesto borrado das mãos em queda (talvez de súplica por sua vida) 
de uma das vítimas. Anos depois, Guzmán filma o quadro que veio da fotografia. Ao fazer isso, ele lança uma nova interpretação sobre essa imagem. A fotografia original mostra uma massa de corpos humanos amontoados em uma das ruas próxima ao Palácio. Essa massa corpórea pertence aos guardas do presidente Allende no momento que eles foram capturados pelas forças militares. No topo se destaca duas mão levantadas. A pintura de Balmes explora o gesto borrado das mãos em movimento, recortando uma parte da fotografia e colorindo o preto e branco original. A interpretação sobre o gesto borrado de Balmes demonstra a dificuldade de se fixar um momento do passado e ao natural desafio da memória, das vicissitudes de ser testemunha em um evento que contêm diversos ângulos e canais de transmissão.

As pinturas de Balmes não se referem somente à violência passada, mas também a dificuldades de reter a imagem fixa. Isso abre a possibilidade de reconsiderar a condição ambivalente dos documentos históricos na medida em que eles se tornam parte de um arquivo que é afetado pela sua capacidade de ocultamento (Rodríguez, 2007:33).

Guzmán, após filmar a tela de Balmes, preenche o quadro com a fotografia original e inicia seu trabalho pessoal de reelaboração do que a pintura de Balmes sugere. Primeiramente, ele dá um zoom in na fotografia, aproximando-se do enquadramento feito pelo pintor para, em seguida, realizar movimentos na foto refazendo o gesto borrado das mãos e corpos.

Mais adiante Juan, o ex-guarda de Allende que aparece no começo do filme, reconhece que aquelas mãos são as dele. Assim, a transmissão de um mesmo evento, a retirada e prisão dos guardas de Allende no dia do golpe, se apresenta pela combinação de diversas fontes que inclui: os depoimentos pessoais (o de Juan e de outros guardas), fotografias, filme, a pintura de Balmes e as reações das testemunhas aos diferentes materiais visuais que Guzmán apresenta.

O material desse passado abre espaço para a reflexão. A forma que a fotografia é trabalhada em Chile, memória obstinada não segue somente a qualidade chamada por Roland Barthes de certificado de presença, do "isso foi"; Barthes nos fala, ao ver uma fotografia: “aquilo que vejo não é uma recordação, uma imaginação, uma reconstituição [...] mas o real no estado passado: simultaneamente o passado e o real.” (Barthes, 2006:93). Certamente, como Barthes acredita, se o que vemos nessa fotografia são pessoas caídas próximo à 
soleira do Palácio é porque há uma confirmação de que essas pessoas estiveram lá, há uma materialidade; mas não existiria também nessa foto algo para além da fotografia - algo extrafotográfico -, uma imaterialidade? Se, como disse Bergson, “toda percepção já é memória” (Bergson apud Rouillé, 2009:218), ao olharmos uma fotografia, assim como fazem os personagens no filme de Guzmán, estamos também suscitando interrogações, evocando e elaborando a memória e o discurso sobre o passado.

A imagem fotográfica mostra-se, então, perpassada por dois grandes modos, um afirmativo, outro interrogativo. O primeiro modo é o do "isso foi", da "constatação de presença" física, o modo dos corpos, das coisas e dos estados de coisas: é o modo da matéria, da impressão. O segundo modo é o do "o que foi que aconteceu?", o modo dos eventos fotográficos e extrafotográficos: é o modo dos incorporais, da escrita, da memória" (Rouillé, 2009:221).

Esses dois modos apontados por André Rouillé estão presentes em Chile, memória obstinada, na medida em que existe um caráter muitas vezes fotográfico do filme, "a ideia do filme como fotografia" (Bellour, 1997:134). Vemos algumas vezes a fotografia tomar conta do quadro fílmico (fotogramas em movimento que reproduzem o caráter estático da imagem fotográfica), no qual o movimento dessa imagem parada e os cortes em sua escala correspondem o olhar que passeia sobre ela (fig 10). Em outros casos Guzmán filma as fotografias sendo manipuladas e comentadas pelas pessoas que ele está entrevistando (fig. 11). E, ainda, por meio de uma televisão, ele congela fotogramas de seu filme $A$ Batalha do Chile para que seus personagens se confrontem com sua imagem enquanto jovens (fig. 12).
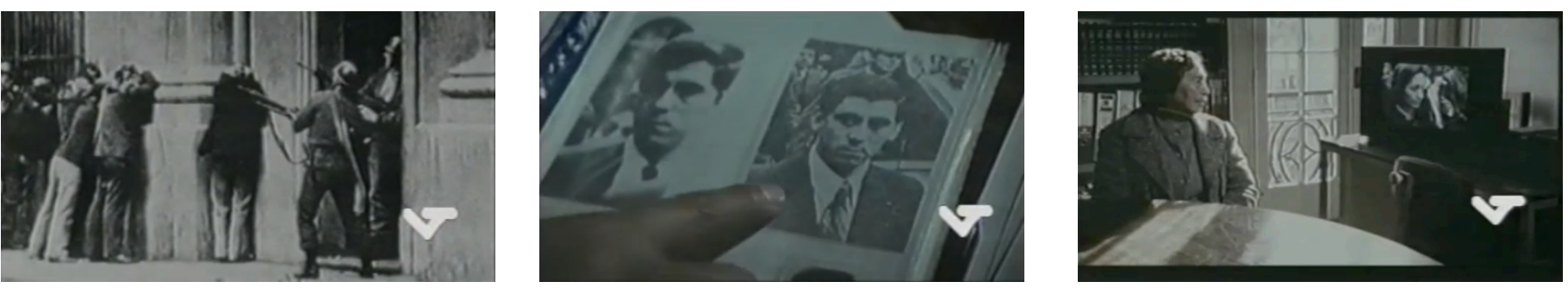

Figuras 13, 14 e 15: Exemplos das diversas formas de utilização da imagem fixa no filme.

Podemos também observar a repetição de um gesto que se inicia em Pueblo en Vilo e que o acompanhará ao longo de seus filmes. Guzmán frequentemente dispõe seus personagem de fronte à câmera, como se ela fosse um aparato fotográfico mais do que uma câmera de captação contínua da imagem. As 
pessoas "posam" para a câmera, olham diretamente para a objetiva. Esse seu gesto, que também estará presente em Nostalgia da Luz, reforça a ideia de Guzmán de que o documentário constitui uma espécie de "álbum de fotografia" de um país, o filme é uma forma de fotografia viva, um retrato da fisionomia e da memória dessas pessoas que posam para a câmera.

Em uma exibição pública de $A$ Batalha do Chile que vemos em Chile, memória obstinada, Guzmán pede para as pessoas que elas identifiquem os atores sociais que aparecem ao longo do filme. Pouco a pouco, elas localizam os companheiros que desapareceram e os que ainda estão vivos. Diante de uma cena do filme exibido onde há uma passeata da Unidade Popular, duas mulheres identificam uma moça. Guzmán para o vídeo para as mulheres terem certeza - a imagem congelada é de Carmen Vivanco. A sequência seguinte é numa sala. Vemos Carmen Vivanco envelhecida diante de uma televisão com a mesma imagem da sequência anterior congelada (fig. 12). Guzmán lhe pergunta: "É você essa pessoa ai?" Ela responde: “Tenho minhas dúvidas. Pode ser quando estava jovem. Essa é uma imagem antiga." O diretor rebate: "23 anos". Carmen conclui: "Pode ser, mas tenho minhas dúvidas."

Enquanto Juan consegue se identificar através de um fragmento de seu corpo na fotografia, Carmen não consegue assimilar sua imagem do passado mesmo quando há confirmação por outras pessoas; sua dúvida é uma resistência à lembrança, especialmente quando esse passado é um evento extremamente traumático. Ficamos sabendo através de seu depoimento que ela possui cinco parentes desaparecidos, incluindo marido e filhos. Primo Levi, um dos sobreviventes de Auschwitz, escreveu: "a recordação de um trauma, sofrido ou infligido, é também traumática, porque evocá-la dói ou pelo menos perturba" (Levi, 2004:20). As ditaduras da América Latina "reforçam a ideia de que a guerra ocorre no interior do espaço social, e que todos devem estar em alerta" (Ginzburg, 2001:142). O silêncio de Carmen durante os anos de ditadura é sua forma de sobrevivência, sem interlocutores para ouvi-la, ela permaneceu calada colaborando para a degradação da memória social das vítimas. O papel de Patricio Guzmán é de ouvir as pessoas, vasculhar as fronteiras desses silêncios e "nãoditos", pois como aponta Michael Polack: "para poder relatar seus sofrimentos, uma pessoa precisa antes de mais nada encontrar uma escuta" (Polack, 1989:6). Apesar das dúvidas sobre seu próprio passado, Vivanco consegue contar 
verbalmente seus traumas para Guzmán; no entanto, o mesmo não acontece quanto o diretor visita Don Rodolfo, pai de Jorge Muller Silva. Muller fora o diretor de fotografia de Guzmán desde seu primeiro filme El primer Año (1971) e desapareceu em 1974, vítima do regime de Pinochet. Seu nome é visto na dedicatória de A Batalha do Chile. Em Chile, memória obstinada, Guzmán novamente rememora a figura de seu amigo - o que corrobora para a leitura de que Chile, memória obstinada é tanto a continuação de $A$ Batalha do Chile quanto um reforço de suas imagens e efeitos.

Guzmán não só evoca a memória de seu amigo ao mostrar as cenas de $A$ Batalha do Chile filmadas por ele, mas vai incorporar os próprios movimentos de câmera feitos por Muller. Reconstituindo, assim, seu olhar fantasmagórico no tempo presente. Esse procedimento fica claro na sequência, já examinada neste trabalho, da sacada do Palácio de La Moneda. Don Rodolfo é o único personagem do documentário que permanece em silêncio. Tendo chegando com 15 anos ao Chile, após escapar do Holocausto, a decepção pelo desaparecimento de seu filho, anos depois da experiência desse primeiro evento traumático, não permite que ele crie um discurso sobre a perda de Muller. Sentado em silêncio, Don Rodolfo olha para frente, seu silêncio é rompido por um choro contido, não ouvimos a pergunta de Guzmán, mas sabemos que se trata de seu filho. No plano seguinte o vemos andando pela mesma sala: ele pega o fotômetro de Muller e o dispõe sobre a mesa junto às poucas fotografias que restaram dele. Sua mudez é uma resposta ao passado que permanece recalcado (que também pode ser lida como uma atitude política), a consequência de um trabalho de luto não resolvido.

\section{3}

\section{Atos de memória corporalizados}

Chile, memória obstinada é, ele próprio - seu processo de filmagem -, uma ação de memória constante, que possibilita a reconstrução e manutenção de uma memória coletiva. As imagens que se produzem são fruto do embate constante de Guzmán com os lugares e pessoas que vivem hoje no Chile. No entanto, há algumas sequências que os "atos de memória corporalizados" 
(Rodríguez, 2007:29), isto é, a ação de evocar as memórias através da repetição de gestos, são mais dramatizados, estando como que corporalmente presentes no filme.

A primeira delas é a sequência na qual vemos uma banda tocar a música "Venceremos"19 da Unidade Popular, no centro de Santiago. Depois de mais de duas décadas, ela ressoa novamente pelas ruas. Uma banda de jovens, a convite de Guzmán, aceitou tocar a partitura de Sérgio Ortega, que estava exilado na França. No início da sequência, temos a imagem de uma calçada larga com a banda avançando em direção à câmera. A música surge em um crescente, como que rompendo pouco a pouco com aquele dia tranquilo de sol. Vemos algumas pessoas lendo jornal, uma mídia oficial que por muito tempo ocultou o que acontecia no país. Alguns transeuntes jovens parecem não entender do que se trata naquela marcha, outros mais velhos olham admirados (talvez assustados). Um senhor faz o gesto de "V" com os dedos. Um outro, em cadeira de rodas, passa por entre a banda sorrindo. O som diegético que acompanhava as reações das pessoas na rua se torna incidental através das caixas de som. A música "Venceremos" continua, mas, agora, dentro de uma sala escura onde é exibida, para um público de jovens, uma cena de uma grande passeata da UP do filme A Batalha do Chile. Guzmán narra: "23 anos de censura e de autocensura, a maioria da juventude chilena cresceu sem saber o que se passou."
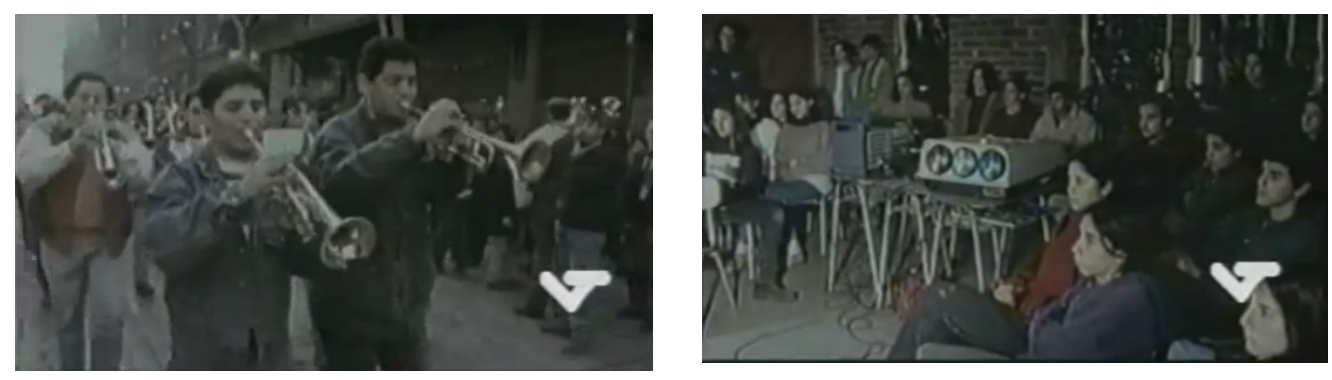

Figuras 16 e 17: a música "Venceremos" começa a ser tocada na rua e termina numa sala de projeção.

Essa sequência demonstra como Guzmán está preocupado com a geração jovem. A dedicatória a suas filhas no início do filme é uma forma de chamar

\footnotetext{
19 "Venceremos" foi escrita por Claudio Iturra e composta por Sérgio Ortega. Para a campanha de 1970 uma segunda versão foi escrita por Victor Jara, músico e professor que desempenhou um importante papel cultural nesse período. Foi torturado e morto após o golpe de 1973, mas somente em 1990, por meio da Comissão da Verdade e da Reconciliação, o Estado Chileno reconheceu seu assassinato. O antigo Estádio Nacional do Chile, onde o músico foi morto, foi renomeado, em 2003, para Estádio Victor Jara.
} 
atenção de que ele, Patricio Guzmán, sobreviveu e pôde ter suas filhas. Muitos dos jovens que vivem hoje no Chile são, de alguma forma, também sobreviventes, vítimas ou algozes do período ditatorial. A juventude pode assumir um papel ativo na construção de um conhecimento melhor: o filme dá voz a elas e procura ser um espaço estimulante para o trabalho da memória a ser realizado para aqueles aos quais informações foram negadas ou distorcidas. Inclusive, ficamos sabendo pelos créditos finais que as filhas de Guzmán trabalharam como assistentes de direção, mais uma evidência de que, para o diretor, essa nova geração precisa estar envolvida no trabalho de arqueologia dos acontecimentos passados.

Outra sequência que dramatiza a ponte entre o presente e o passado mostra os ex-guardas de Salvador Allende que escoltam um carro vermelho. Em um primeiro momento, o carro parece estar vazio, como se as mãos dos guardas estivessem movimentando o veículo. No entanto, o que a sequência sugere é a reconstituição da visão de um outro ator social, assim como Guzmán faz ao reproduzir os movimento de Jorge Muller Silva. A câmera se posiciona acima do carro, como se alguém estivesse em pé, olhando por cima do capô. A simulação do olhar de Allende se confirma quando vemos o presidente, recém eleito, desfilar em pé em um carro em 1970. A reconstituição desse momento não procura restituir o momento histórico ao qual se refere mas, antes, promover uma transição afetiva para uma figura que está perdida na memória de muitos. O plano que antecede essa sequência é um travelling lateral de uma estante que contém os arquivos de desaparecidos políticos. Enquanto a câmera em contra-plongée (um ponto de vista mais terreno, subterrâneo) percorre os arquivos ao som de uma sonata de Beethoven, a sequência do carro se inicia com um plano em plongée (um ponto de vista mais solene, esclarecedor); a sequência rompe com a ideia da perda e contribui para que tenhamos um momento de esperança.
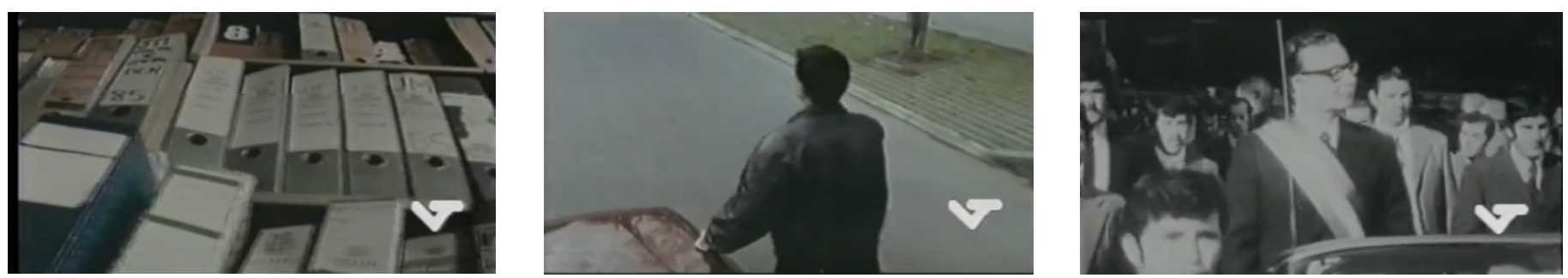

Figuras 18, 19 e 20: fotogramas da sequência da escolta do carro de Salvador Allende. 
Ao longo do filme, ouvimos uma sonata de Beethoven tocar, o trecho é relativamente curto e sua execução e qualidade de gravação não são precisas. Ela surge em momentos que se relacionam ao trabalho de recordação: 1) quando vemos as fotos e filmagens feitas no dia do golpe com a voz de Juan contando os detalhes daquele dia; 2) na sobreposição composta por Guzmán na qual vemos a imagem de Carmen Vivanco jovem e seu reflexo atual na superfície da televisão; 3) no travelling sobre os arquivos dos desaparecidos; 4) nas fotografias e filmagens feitas de Jorge Muller Silva.
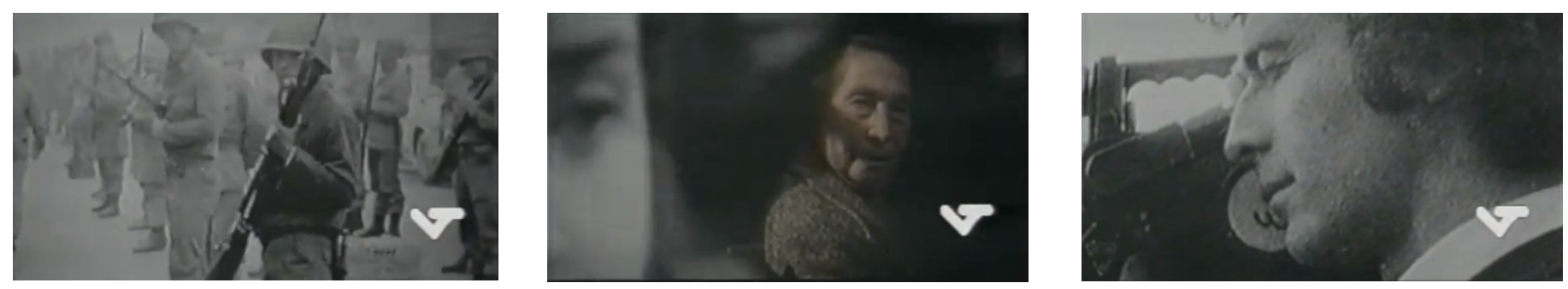

Figuras 21, 22 e 23: fotogramas onde ouvimos a sonata de Beethoven.

No entanto, já no final do filme, Guzmán revela que a música de Beethoven não é simplesmente uma trilha para esses momentos de recordação. Em uma sala ampla, vemos um senhor tocando um piano de cauda. "Esta é a única pessoa de minha família que ainda sobrevive. É o meu tio Ignacio que fez 80 anos e creio que tem uma boa memória." A câmera se aproxima lentamente até parar no momento em que seu tio erra a partitura e diz: "Errei. Outra vez". Reiniciando a música. Novamente ele erra as notas e balbucia algo, como que acusando o piano pelo erro dele. Pelo plano fechado das mãos tocando as teclas vemos o nome "August" no piano; esse plano nos remete ao primeiro nome do ditador Augusto Pinochet - a figura dele (que nessa época ainda exercia a função de Chefe das Forças Armadas) e o que seu regime representou continua a ser um obstáculo para o trabalho de memória e da restauração da justiça. Sua luta para relembrar a sonata de Beethoven é uma metáfora da luta contra o regime de August(o) Pinochet. Essa última sequência talvez seja o "ato de memória corporalizado" mais significativo, pois não só se restringe ao personagem de seu tio, mas se refere ao filme como um todo, como uma representação da luta de todos - e inclusive do próprio filme - na obstinada tentativa de preservar a memória. 

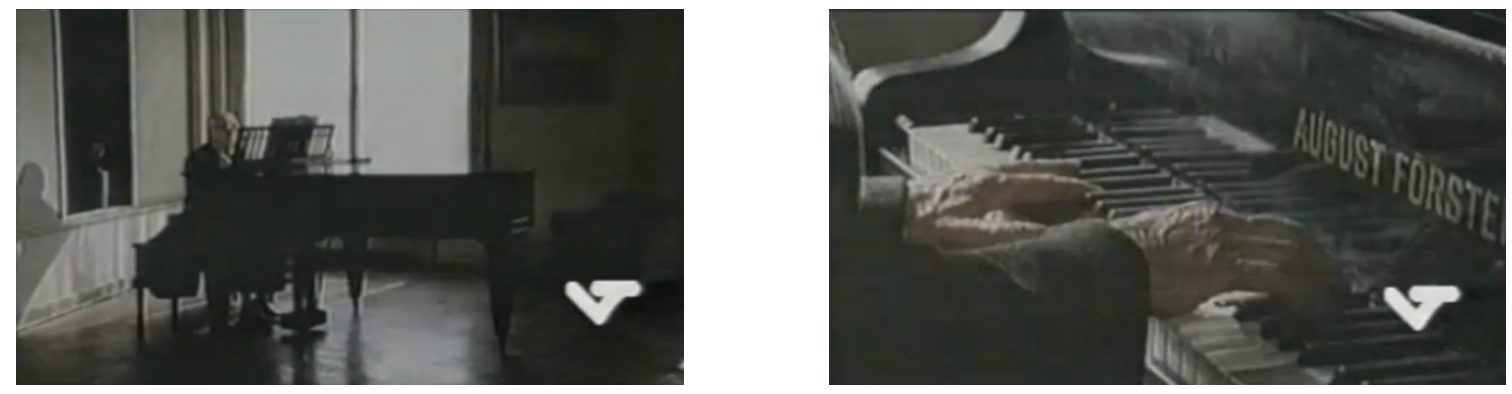

Figuras 24 e 25: sequência do tio Ignacio ao piano.

Essa luta, afinal, é a própria batalha do Chile. Guzmán deixa claro isso quando mostra seu tio falando sobre como guardou os rolos de película de $A$ Batalha do Chile em sua casa. Enquanto tio Ignacio comenta os detalhes de como os rolos saíram do país em um barco Suíço, vemos a cartela A Batalha do Chile: a luta de um povo sem armas. Ele ainda comenta: "sei que tinha que fazer, não somente por você, mas pelo que significava, para recordar depois."

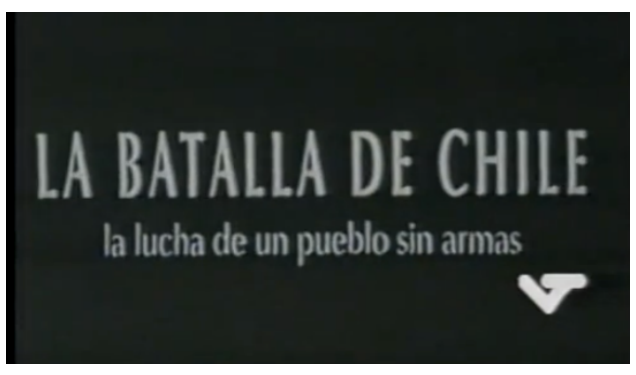

Figura 26: fotograma retirado de seu filme $A$ Batalha do Chile.

Essa cartela é a evidência de que o tio Ignacio exerceu um papel importante para que $A$ Batalha do Chile pudesse ter sobrevivido e que, em última instância, o próprio filme Chile, memória obstinada exista. Além disso, "a luta de um povo sem armas" é dizer, hoje, que a forma de se combater o legado traumático da ditadura é através de um trabalho intelectual e articulado de todas as gerações de chilenos na recuperação e preservação de suas memórias e na retomada narrativa da história do país. 


\section{4}

\section{Ponte por cima da ruptura}

Chile, memória obstinada é construído, em parte, pela busca de personagens anônimos de A Batalha do Chile. Trata-se de uma busca parecida a de Eduardo Coutinho em seu filme Cabra marcado para morrer (1984). Coutinho volta a Pernambuco, ao Engenho de Galiléia, onde 17 anos antes havia iniciado seu projeto de filme de Cabra marcado para morrer (Cabra/64) no qual pretendia contar a história de João Pedro, líder das Ligas Camponesas da Paraíba, assassinado em 1962. No entanto, ainda com as filmagens em andamento, Coutinho se vê obrigado a abandonar a cidadezinha e fugir para Recife após o golpe civil-militar em abril de 1964. A polícia apreende parte do material filmado e dos equipamentos que haviam ficado em uma das casas de Galiléia; sobra apenas os rolos que já haviam sido mandados para revelação. Tanto A Batalha do Chile como Cabra/64 foram interrompidos por golpes militares. A Batalha do Chile, no entanto, se tornou um filme e foi amplamente visto nos festivais Europeus e norteamericanos enquanto Cabra/64 permaneceu adormecido, fragmentos de filme de uma história que, num primeiro momento, seria a história de uma derrota. Com Cabra/84, há "um projeto histórico preocupado em lançar uma ponte entre o agora e o antes, para que o antes não fique sem futuro e o agora não fique sem passado." O Cabra/84 é o resgate de si, do filme interrompido, "resgata os detritos de uma história rompida" - resgate também da memória de João Pedro, agora muito ligada aos personagem que participaram como atores do Cabra/64 e de Elisabeth Teixeira, viúva de João Pedro, que após o golpe mudou seu nome para Marta e se separou dos filhos (Bernardet, 2003:227-228).

Chile, memória obstinada é, assim como fez Coutinho em Cabra/84, a recuperação do passado fragmentado; por isso, a utilização constante, em ambos os casos, de fotografias da época e de projeções de seus filmes para suscitar as memórias dos personagens anônimos, dispersos e oprimidos até então. Esse dispositivo de filmar o filme dentro do filme, do diretor que interpela seus antigos personagens, é a "tarefa do espetáculo" ao se trabalhar "com esses vestígios, desenterrá-los, organizá-los para construir uma coerência - a ponte - sem que, no entanto, se perca a noção de fragmento" (Ibidem:232). 
A análise de Jean-Claude Bernardet sobre Cabra marcado para morrer é útil para se pensar a questão dos vestígios e rastros e sua apropriação material pelo documentário; uma questão que estará presente na análise dos próximos filmes.

O fragmento não é uma arbitrariedade estilística, mas é a própria forma da história derrotada, motivo pelo qual, mesmo na busca de coerência e da significação, o caráter fragmentário não pode nunca ser abandonado. (Ibidem:232-233)

O projeto de Chile, memória obstinada, que também existe em Cabra/84, é lançar uma ponte por cima da ruptura, emparelhando tempos heterogêneos para provocar e resgatar as memórias que se mantiveram silenciadas e sem espaço até então. Com isso, e, assim parece querer Guzmán, o filme pode proporcionar um sentido novo ao passado e um ambiente mais justo e vivo ao presente. ${ }^{20}$

Chile, memória obstinada inaugura um novo impulso na forma de Guzmán trabalhar e articular seu material documental. Ele não mais assume o papel de transmissor de um determinado conhecimento histórico, mas, ao contrário, como veremos de forma mais intensa em seu último filme Nostalgia da Luz, Guzmán se interessa tanto em criar um impacto emocional quanto em apresentar material que possibilite a meditação para a lembrança.

\footnotetext{
${ }^{20} \mathrm{Um}$ outro filme que também articula esse embate entre imagens produzidas num passado e o resultado delas no presente é De volta ao Terceiro Milênio (2009) de Jorge Bodanzky. 30 anos depois o diretor retorna a região de Alto Solimões na Amazônia para exibir seu filme Terceiro Milênio (1979), filmado nesse mesmo local acompanhando a visita do senador Evandro Carreira e sua interação com o povo de Ticuna. De volta ao Terceiro Milênio é fruto do contato entre filme/diretor e os índios Ticunas. Apesar de haver um foco mais amplo que tangencia questões socioambientais da região Norte do Brasil, existe também a preocupação de resgatar/recontar as histórias particulares que surgem como resultado da projeção de seu primeiro filme.
} 


\title{
3. Nostalgia da Luz e o gesto arqueológico
}

\begin{abstract}
A cinematic image of nostalgia is a double exposure, or a superimposition of two images - of home and abroad, of past and present, of dream and everyday life. The moment we try to force it into a single image, it breaks the frame or burns the surface.
\end{abstract}

(Svetlana Boym)

As representações artísticas chilenas no período posterior à ditadura, desenvolvidas inicialmente no exílio e que se deslocaram para país com a redemocratização, assume não só a necessária tarefa de elaborar o passado, mas também, como aponta Idelber Avellar, de "definir sua posição no novo presente instaurado pelos regimes militares: um mercado global em que cada canto da vida social foi mercantilizado" (Avellar, 2003:237).

De fato, essa mercantilização pode ser visto como um modelo que nega a memória, pois sua operação básica é a de que toda nova mercadoria substitui a mercadoria anterior; assim, o passado estaria sempre em vias de se tornar obsoleto. Andreas Huyssen aponta para o paradoxo que se estabelece:

O enfoque sobre a memória e o passado traz consigo um grande paradoxo. Com frequência crescente, os críticos acusam a própria cultura da memória contemporânea de amnésia, apatia ou embotamento. Eles destacam sua incapacidade e falta de vontade de lembrar, lamentando a perda da consciência histórica (Huyssen, 2000:18).

Assim como Huyssen, que discute as transformações ocorridas na sociedade com o aparecimento do que ele denomina de uma cultura da memória, uma cultura, portanto, que estaria ao mesmo tempo operando a substituição do novo em relíquia, mas também com uma obcecada atenção em relembrar e preservar essa mesma relíquia, temos a argentina Beatriz Sarlo com o livro Tempo Passado: cultura da memória e uma guinada subjetiva, onde analisa as sociedades contemporâneas nas quais, concomitantemente à aceleração do tempo, há um movimento de resgate do passado, a partir da musealização, dos romances e filmes históricos e, principalmente, do movimento testemunhal. A autora ressalta que a história e a ciência social voltaram, então, o olhar para os indivíduos, grupos e eventos que não eram narrados na História ou nos estudos da sociedade, como os 
loucos, a festa e a literatura popular, "buscando o detalhe excepcional, o vestígio daquilo que se opõe à normalidade e as subjetividades que se distinguem por uma anomalia, porque apresentam uma refutação às imposições do poder material ou simbólico" (Sarlo, 2007:15-16).

É a partir da análise da sociedade contemporânea, que favoreceu o crescimento da presença da subjetividade e do cotidiano tanto na Academia quanto no mercado de bens simbólicos, que surge, contemporaneamente à guinada linguística nos anos 1970 e 1980, o que Sarlo vai identificar como guinada subjetiva ${ }^{21}$ :

Restaurou-se a razão do sujeito, que foi, há décadas, mera 'ideologia' ou 'falsa consciência' [...] Por conseguinte, a história oral e o testemunho restituíram a confiança nessa primeira pessoa que narra sua vida (privada, pública, afetiva, política) para conservar a lembrança ou reparar uma identidade machucada. (Ibidem:19)

Em meio à velocidade da pós-modernidade - num mercado que submete o passado à imediatez do presente - o cinema arqueológico de Guzmán busca tanto nos testemunhos quanto em fragmentos, vestígios e ruínas (muitas vezes provenientes desse processo constante de substituição) formas para ativar o passado e reconstruir a memória. Ainda que também haja uma mercantilização da memória, é necessário ainda - e cada vez mais - um trabalho sólido para que crimes contra os direitos humanos, por exemplo, consigam ser julgados, bem como possibilitar uma transparência dos fatos ocorridos durante a ditadura de Pinochet, principalmente para as gerações posteriores ao golpe.

Neste capítulo, a atenção recai sobre o que Isis Sadek (2008) denomina de gesto arqueológico de Patricio Guzmán e na sua forma particular de construir sua narrativa fílmica a partir dos vestígios e rastros, dos testemunhos e de sua subjetividade. Nostalgia da Luz (2010) vai combinar algumas práticas e ações de seus dois filmes anteriores, O Caso Pinochet (2001) e Salvador Allende (2004). Apesar de existir, em muitos aspectos, uma aproximação com Chile, memória

\footnotetext{
${ }^{21}$ Esta "guinada subjetiva" vai ser vista com ressalvas. Beatriz Sarlo problematiza os testemunhos da ditadura militar argentina obtidos pela voz de suas vítimas (ex-presos políticos, exilados e perseguidos) nos anos de transição democrática. Isto, porque esses relatos em primeira pessoa foram fundamentais para a reconstrução do passado e a condenação do terrorismo de Estado, já que não havia provas materiais. A crítica de Sarlo é à não reflexão em cima dos relatos das vítimas, embora ressalte que as condenações não seriam possíveis sem eles.
} 
obstinada, Nostalgia da Luz pode, na maneira em que trabalha e manuseia os materiais físicos do filme, ser mais bem compreendido como um amadurecimento desse gesto arqueológico já presentes nesses primeiros filmes da década 2000.

Seu trabalho de memória - e, naturalmente, a reconstrução do passado histórico -, marcado por uma participação mais pessoal dentro dos filmes nesses últimos anos, possibilita uma forma distinta de sensibilidade e reflexão com o público, uma característica latente do documentário performático, que se associa, portanto, à democratização, à luta por direitos humanos e "à expansão e fortalecimento das esferas públicas da sociedade civil" (Huyssen, 2000:34).

O conceito de "rastro", como aponta a filósofa Jeanne-Marie Gagnebin, é caracterizado na sua trajetória filosófica e historiográfica por sua complexidade paradoxal:

Presença de uma ausência e ausência de uma presença, o rastro somente existe em razão da sua fragilidade: ele é rastro porque sempre ameaçado de ser apagado ou de não ser mais reconhecido como signo de algo que assinala (Gagnebin, 2012:27).

Essa estrutura ambígua entre proximidade e distanciamento é encontrada também nos conceitos de aura e rastro desenvolvidos pelo filósofo alemão Walter Benjamin. Gagnebin revisa esse autor e sua reflexão sobre o estatuto paradoxal do "rastro" que estaria ligado à questão da manutenção do passado e também do apagamento desse passado.

É importante destacar que o termo alemão Spuren foi traduzido para o português de diversas formas - traços, rastro, resto, pegada, trilha, vestígio... -, e, além dessa variedade de palavras para um único termo no caso da língua portuguesa, o próprio termo Spuren sofreu inflexões dentro da obra de Benjamin. Portanto, para esse trabalho, o importante é compreender o rastro como uma chave de conhecimento assumindo que "sua maneira de lidar com a questão do vestígio é uma prática historiográfica" (Janz, 2012:21). Dessa maneira, compreendemos o rastro como um elemento importante para renovar e se compreender, de forma mais justa e verdadeira, a memória histórica dos países latino-americanos.

Nesse sentido, o que Guzmán busca são elementos que ele consegue identificar como vestígios e abrir, assim, caminhos para uma história não conservadora, muito marcada por uma política ostensiva do esquecimento, e de dar 
voz aos vencidos - escovando "a história a contrapelo" (Benjamin, 1987:225). Essa política que até hoje permanece entre nós. No caso do Brasil, a dificuldade em abrir os arquivos da ditadura militar é uma dessas perigosas e injustas políticas da memória, bem como nosso insuficiente conhecimento dos genocídios indígenas, da questão da escravidão, das violações dos direitos humanos, das chacinas e desaparecimentos de civis em comunidades urbanas - enfim, os modestos progressos em reverter essa política da memória se deve, em muito, à maneira como ainda a história é ensinada nas escolas.

\section{1}

\section{Pelas paisagens áridas}

A última cena de $O$ poder popular (1979), o terceiro filme da trilogia $A$ Batalha do Chile, termina com um plano do deserto de Atacama. A região é abordada devido as tensões das greves das minas estatizadas pelo governo de Allende. No entanto, essa imagem remete a um espaço de diálogo, combatividade e de esperança - o filme mostra o engajamento e a organização espontânea dos operários para superar as crises encabeçadas pela oposição política. Essa paisagem também traz consigo um teor nostálgico, pois essa cena já é montada por Guzmán em um momento retrospectivo da história; a trilha sonora, inexistente nos dois primeiros filmes, agrega ainda mais o tom emotivo desse plano final. Guzmán finaliza sua trilogia com o cenário árido que concomitantemente estava sendo palco de ações truculentas dos militares.

A região norte do Chile volta ser abordada no trabalho de Patricio Guzmán em seu filme $O$ caso Pinochet (2001). A sequência inicial começa com a paisagem do deserto de Atacama transpassando rapidamente: o som do motor de carro indica que estamos em uma estrada. Em seguida, o automóvel aparece em meio a uma montanha, a câmera lentamente faz um zoom out até fazer o carro desaparecer na imensidão. Lemos a seguinte legenda: "Norte do Chile, ano 2001. O Juiz Guzmán busca os corpos dos desaparecidos de Pinochet." (Curiosamente, o juiz, que, em seu ofício, produz documentos, e que está sendo apresentado no documentário de Patrico Guzmán, tem o mesmo sobrenome que ele, chamando-se Juan Guzmán). 
Após o letreiro que nos situa no espaço e tempo da narrativa, vemos um outro ponto de vista do deserto: um vale com a cordilheira dos Andes enevoada ao fundo - em primeiro plano, as rochas parecem estar engolindo a paisagem. A tensão presente nesse cenário indica que sua própria imagem corre perigo, o tempo como que se apressa em apagar os traços do passado violento que existiu ali. A sequência nos revela de antemão o árduo e complicado trabalho de encontrar os vestígios e a verdade dos desaparecidos políticos. Se perdemos de vista o carro do investigador, como será para encontrar os corpos?
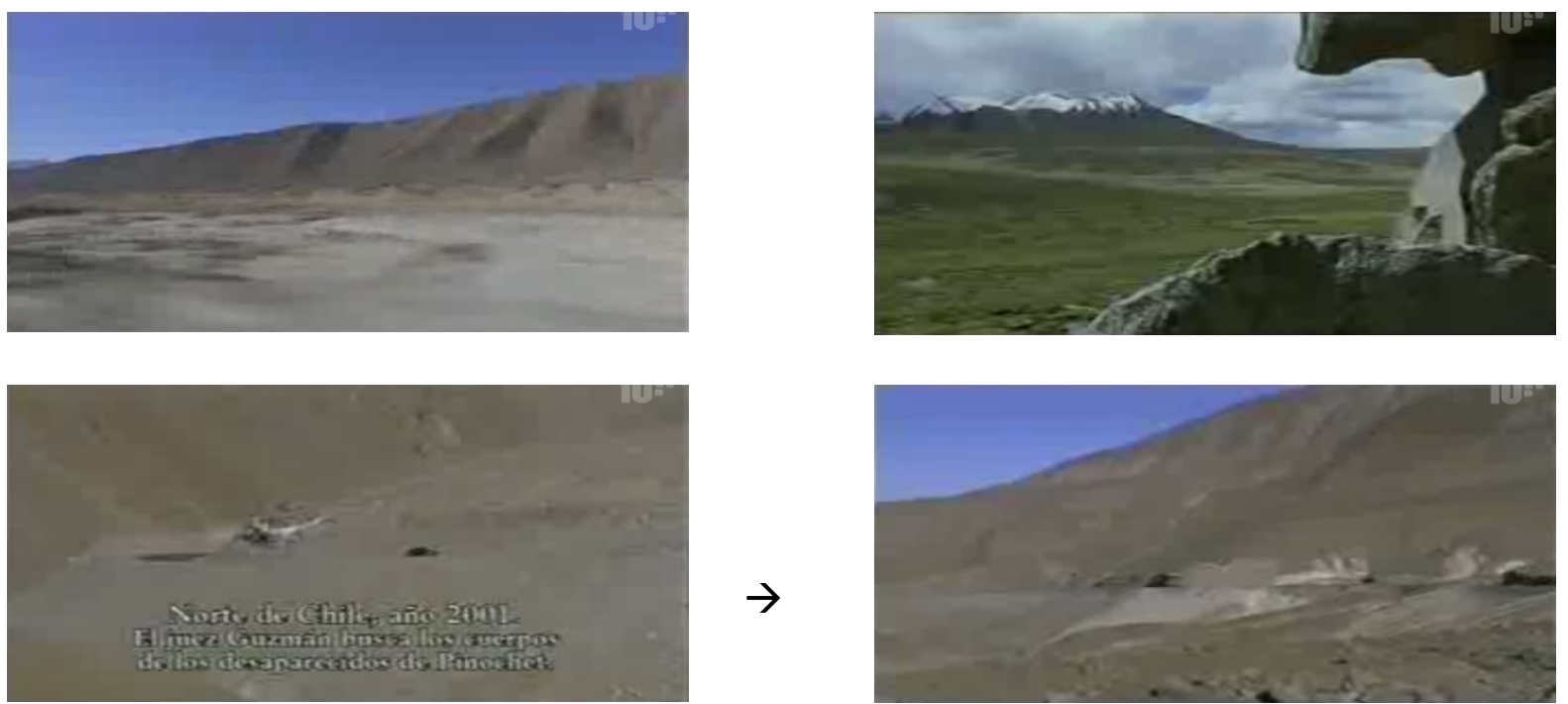

Figura 27, 28 (da rocha em primeiro plano) e 29 (pan que acompanha o carro): imagens do deserto no filme $O$ caso Pinochet.

Com essas cenas, o documentário aproxima não somente o processo judicial referente ao julgamento de Pinochet, mas também consequências mais extremas dele: como descobrir os rastros e inscrevê-los nessa paisagem? Vemos o Juiz Juan Guzmán acompanhando as diversas ações de uma equipe forense: as medições do terreno, o garimpo e o arado do solo, a categorização dos ossos encontrados e, talvez a ação mais impactante, a reconstituição com pessoas vivas da posições dos corpos que foram exumados de uma vala.

O fato do processo estar sendo realizado no ano de 2001, mais de uma década após o fim da ditadura, já demonstra que, em muito, as forças do esquecimento se impuseram. Nos embates e negociações que resultam na memória que é formada pelas pessoas que viveram um determinado evento, observamos a predominância dos que preferiram "virar a página" e enterrar a memória (Seligmann-Silva, 2012.b:64). 
O documentário enfatiza a falta de uma "postura de escuta" por parte da sociedade chilena. Dessa forma, o filme se apresenta numa confluência de diversos discursos: o testemunho de familiares e sobreviventes, as explicações legais e jurídicas feitas por advogados, a crônica da prisão de Pinochet em Londres feita por um jornalista espanhol, além das informações forenses feitas por especialistas. “A exigência de justiça busca mostrar que é possível (re)nomear os desaparecidos e (re)inscrevê-los na história do país, processando jurídica e simbolicamente esse passado" (Almeida Telles, 2012:117). A possibilidade de um processo jurídico contra Pinochet é, assim como os testemunhos colhidos por Patricio Guzmán, a maneira possível para combater o silêncio e o esquecimentos introduzidos pelos terror do desaparecimento. A ausência do corpo e a impossibilidade de realizar um ritual fúnebre pode acarretar, para as pessoas vivas, a dificuldade de que realizem o luto pela morte de alguém próximo; pois, se a falta do corpo sugere a morte, essa mesma ausência não permite a realização da morte no imaginário do enlutado.

De sua filmografia, $O$ caso Pinochet é o filme onde a questão do desaparecimento dos corpos e da tortura se darão de forma mais frontal - temos uma série de testemunhos de familiares de desaparecidos e de sobreviventes. Um tema que, como veremos mais adiante, será, com nuances e abordagens diferentes, também central no discurso de Nostalgia da Luz.

O deserto de Atacama reaparece, mais uma vez, no filme, mas, nesse segundo momento, sem a presença de qualquer pessoa. Após acompanharmos Gladys, uma das sobreviventes, à Villa Grimaldi² ${ }^{22}$ um corte nos direciona ao plano do solo do deserto se remexendo, como se os mortos sem tumbas estivessem ganhando vida; é uma plano curto, mas muito forte simbolicamente: é, afinal, uma

\footnotetext{
${ }^{22}$ El Cuartel Terranova foi mais conhecido como "Villa Grimaldi". Começou suas atividades represivas já no fím de 1973, quando a Dirección de Inteligencia Nacional (DINA), a cargo do Coronel do Exército Manuel Contreras adquiriu a propriedade na Av. José Arrieta 8.200 (atual 8.401), que pertencia a Emilio Vasallo e que foi obrigado a vender para proteger sua família. De acordo com testemunhas, passaram por Villa Grimaldi em torno de 4.500 prisioneiros e prisioneiras, dos quais 236 foram assassinados e que ainda permanecem desaparecidos. Em 1978 as atividades no local foram encerradas e após anos de abandono foi, em meados da década de 80 , desmontada e posteriormente vendida para uma sociedade construtora constituída de familiares do último diretor da Central Nacional de Informaciones (CNI), Hugi Salas Wenzel, que demoliram o local com o objetivo de construir um conjunto habitacional. Alertados com essa situação, um movimento civil liderado pela Asamblea Permanente por los Derechos Humanos de Peñalolén y La Reina, iniciou uma campanha de denúncia e recuperação de Villa Grimaldi. Através de um projeto de lei na câmara dos deputados, o Estado expropria o terreno. O local se abre pela primeira vez à comunidade no dia 10 de dezembro de 1994. Mas foi em março de 1997 que o Parque por La $P a z$ foi inaugurado, permanecendo, desde então, aberto ao público.
} 
representação da fala de Gabriela, uma outra vítima, quando ela diz: "minha vingança é estar viva". Ao filmar as pedras rolando com vida própria por esse cenário, o diretor mostra que as memórias subterrâneas estão vindo à tona. A história oral, colhida nos testemunhos de grupos que por tanto tempo foram reprimidos, ressalta a importância das memórias subterrâneas que, como parte integrante das culturas minoritárias e dominadas, se opõem à "Memória Oficial", que, no caso, é, ainda, a memória nacional. Guzmán traz à superfície as memórias "que prosseguem seu trabalho de subversão no silêncio e de maneira quase imperceptível afloram em momentos de crise em sobressaltos bruscos e exacerbados" (Pollack, 1989:4).

A sequência que antecede à imagem do solo árido do deserto é a do centro de detenção e tortura Villa Grimaldi, que fica nos arredores de Santiago. Hoje convertido em Parque por la Paz Villa Grimaldi ${ }^{23}$, um memorial para as vítimas que passaram por lá.

Villa Grimaldi, enquanto espaço físico de suas construções antigas, não existe mais (apesar de algumas reconstituições terem sido feitas para os visitantes recentemente). O espaço em ruínas é a comprovação da "presença de uma ausência", o incompleto acesso à memória histórica. Guzmán irá explorar os elementos da arquitetura de Grimaldi para representar esse passado violento sem, com isso, buscar domar a memória, mas, antes, nos sensibilizando e abrindo um caminho para compreendermos a complexidade própria à discussão sobre o passado traumático. Essa investigação através das reminiscências arquitetônicas desse período será vista também em Nostalgia da Luz, quando visitamos Chacabuco, uma cidade fantasma da Era do Nitrato no século XIX, que foi transformada em campo de concentração após o golpe.

Através de uma maquete de Grimaldi tal como era nos anos 70, Guzmán percorre o centro de detenção e tortura enquanto os sobreviventes relatam como eram as atividades no local. O desenho será também outra forma de explorar essa arquitetura, uma estratégia semelhante a que existe em seu último filme com o

\footnotetext{
${ }^{23}$ As visitas no Parque por La Paz Villa Grimaldi nos últimos três anos (2010, 2011 e 2012) somam 30.548 (dados disponíveis em http://villagrimaldi.cl/transparencia-2/ acessado em 26/12/2013), enquanto, para efeito de comparação, no Memorial e Museu Auschwitz-Birkenau, só no ano de 2012, o número atingiu mais de 1,4 milhões de visitantes.
} 
arquiteto Miguel Lawner. ${ }^{24}$ A câmera mostra Ofelia rabiscando em uma superfície branca traços dos lugares pelos quais passou. Guzmán também intercala esses desenhos com imagens atuais (2001) das ruínas dos portões, pátio e quartos de Villa Grimaldi. Com isso o filme proporciona um tour por "lugares imaginários, tendo em vista que muito das estruturas originais usadas para tortura foram demolidas pelos militares" (Gómez-Barris, 2009: 43). Mesmo assim, apesar desse trabalho de memória e reconstituição, os acontecimentos "continuam sendo singularmente opacos quando realmente queremos compreendê-los", uma dificuldade que também é inerente ao estatuto do testemunho. Como Giorgio Agamben proclama:

A dificuldade tem a ver com a própria estrutura do testemunho. Por um lado, o que aconteceu nos campos [campos de extermínio de judeus] aparece aos sobreviventes como a única coisa verdadeira e, como tal, absolutamente inesquecível; por outro , tal verdade é, exatamente na mesma medida, inimaginável, ou seja, irredutível aos elementos reais que a constituem. (Agamben, 2008:20)
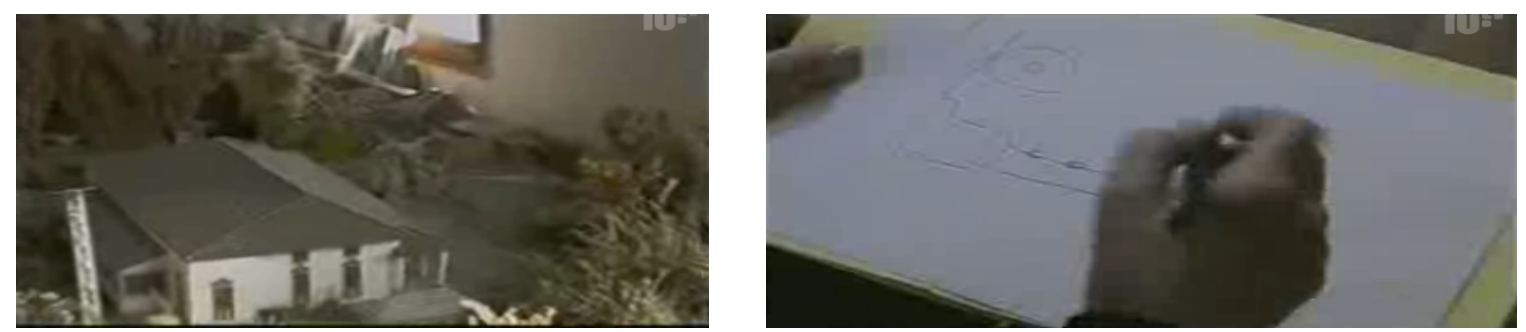

Figuras 30 e 31: A maquete e o desenho como formas de reconstrução de Villa Grimaldi

De qualquer maneira, a questão não é a reconstituição do passado "como ele de fato foi”, mas, antes, deixar evidente o "caráter fragmentário" que Bernadet muito bem alertou, ou seja, a própria estrutura do documentário, ao usar diferentes estratégias de representação do passado, é o resultado natural de se trabalhar no campo de uma "história derrotada" (Bernadet, 2003:233).

A dita democracia entre comillas (democracia entre aspas), democracia cupular (democracia elitista), democracia lite (democracia de baixa caloria) ou

\footnotetext{
${ }^{24}$ Apesar de não estar presente em $O$ caso Pinochet, os desenhos de Lawner que retratam os ambientes internos dos campos de concentração pelos quais passou, incluindo Villa Grimaldi, serão apresentados em Nostalgia da Luz; todos os desenhos foram feitos posteriormente, a partir de sua memória, e impressionam pela riqueza de detalhes.
} 
democracia restringida são descrições críticas sobre o processo pouco democrático que o Chile viveu posteriormente (Goméz-Barris, 2009:16). A fala de Gabriela critica justamente o discurso oficial de reconciliação social quando ela explica para Guzmán suas razões de por que somente a vítima, e não o Estado, seria capaz de perdoar os agressores:

Eu me sinto capaz de viver com o passado - não? Capaz de viver com o passado. No entanto, se me vem a cabeça a pergunta que todos sempre fazem: não seria melhor você esquecer? Tem que perdoar...eu já escutei tantas vezes. Tem que esquecer. Eu acredito que os únicos que podem perdoar são os que sofreram. Ninguém mais pode perdoar por eles.

Gabriela acredita existir uma possibilidade para o perdão. Mas, para que ele exista, primeiro há de se reconhecer o que foi feito. O pedido de perdão depende da capacidade da sociedade interromper o processo hegemônico de esquecimento, de um discurso de não responsabilização e do negacionismo ${ }^{25}$.

A prisão do general Pinochet em Londres, em 1998, levou a que o debate político chileno voltasse a considerar as violações dos direitos humanos e a impunidade de seus responsáveis no alto escalão: uma reflexão necessária para a qual o filme contribui ao iniciar com a cena no deserto, a procura pelo paradeiro dos desaparecidos, e ao finalizar com a inauguração da estátua de Salvador Allende na praça principal do Palácio de La Moneda.

\footnotetext{
${ }^{25}$ Manuel Contreras, ex-diretor da DINA, a polícia secreta chilena durante o governo militar do general Augusto Pinochet, concedeu uma entrevista para a CNN Chile nas vésperas dos 40 anos do Golpe (10/09/2013). A respeito dos detidos e desparecido ele afirma: "os detidos desaparecidos estão todos ai, existe mil no Cemitério General, nos patio 9, 12, 24, 25, 26, 27, 28 e 29, em fossas comuns e que foram entregados ao Serviço Médico Legal", complementando que "a DINA não lançou corpos ao mar". Ainda, "Não morreu ninguém em um centro de detenção da DINA (...) não pergunte a mim. A DINA não tinha nem barcos nem helicópteros. Ninguém foi lançado ao mar, todos foram levados ao Serviço Médico Legal". Entrevista completa em: http://www.youtube.com/watch?feature=player_embedded\&v=NIZZediL1Gw (acessado em
} 27/12/2013). 


\section{2 \\ O gesto arqueológico}

Amontoado em cima de um tampo de madeira de uma mesa, alguns poucos objetos ao centro podem ser vistos. As mãos de Guzmán entram em quadro e pegam o que parece ser uma carteira. Ele narra: “ Isso é quase tudo que restou de Salvador Allende..." (grifo meu) e prossegue: "Em seu corpo sem vida encontraram esses objetos, história fragmentada."

Patricio Guzmán incorpora uma atitude do materialismo histórico de Walter Benjamin ao se interessar por essa história fragmentada - pelos, como alenta Jeanne Marie Gagnebin, "elementos de sobra do discurso histórico” e ainda, ao descrever esse narrador que tem o desejo de não deixar nada se perder:

Esse narrado sucateiro (o historiador também é um Lumpensammler) não tem por alvo recolher os grandes feitos. Deve muito mais apanhar tudo aquilo que é deixado de lado como algo que não tem significação, algo que parece não ter importância nem sentido, algo com que a história oficial não sabe o que fazer (Gagnebin, 2006:54).

É em Salvador Allende (2004) que o gesto arqueológico de Guzmán se intensifica - além do gesto do filme como atividade arqueológica (isto inclui pensar que esse gesto também se faz na ilha de montagem, no corte, no enquadramento, na escolha do material de arquivo utilizado, na decupagem que desdobra e recorta a ação) suas mãos entrarão em ação para desvelar o que aparentemente não conseguimos ver. Nessa parte introdutória do documentário já vemos as mãos vasculhando alguns objetos de Allende, são eles: sua carteira, uma faixa presidencial, um caderno de membro do partido socialista, uma caixa de óculos com suas iniciais e um relógio de pulseira. Prossegue sua narração: "Rastreando em museus e arquivos, hoje, somente esse único fragmento é visível ao público." Esse único fragmento são os óculos de Allende destroçados; todos os outros objetos com os quais "a história oficial não sabe o que fazer" ficaram ocultos ao público e essa única peça, pela insuficiência de explicação do que ela mesma representa, acaba por não articular uma relação dos visitantes com o presente. A figura de Allende foi sendo por muitos anos apagada ou pouco rememorada por instituições como os museus e memoriais; no entanto, Guzmán parece querer evocá-la pela materialidade do que encontra no caminho. 
No plano seguinte, após o letreiro com o nome do filme, ouvimos o som de uma autoestrada, com carros e caminhões em grande velocidade - seria aqui a velocidade incessante da pós-modernidade? - enquanto o som constante de carros invade o plano, o que se vê é um muro branco de pedras. Sabemos pela narração que o muro fica perto do aeroporto, onde, 30 anos antes, Guzmán, após ter sido solto depois de duas semanas detido no Estádio Nacional, passou pela última vez antes de ir para o exílio. Estamos fora do museu, do espaço destinado às memórias oficializadas, sacralizadas pelo trabalho da instituição. Essa mudança brusca do espaço acompanha a fala do diretor, que nos diz: “A aparição da memória não é nem fácil nem voluntária, é sempre perturbadora." A câmera lentamente faz um zoom in para um local do muro que está levemente descascada, revelando a coloração de sua camada antiga. Ele começa a abrir o buraco da camada superficial com as suas unhas até pegar uma pedra e começar a golpear o muro com força; uma coloração azul e amarela surge. "A história não passa" diz Guzmán. Ao falar isso, uma fala que está presente em outros momentos do filme, o diretor indica que a história de um passado ainda é a história desse presente, do agora. De fato, segundo Benjamin: “ A história é objeto de uma construção cujo lugar não é o tempo homogêneo e vazio, mas um tempo saturado de "agoras" (Benjamin, 1987:229). Ao descascar a camada de tinta, ele desvela, com suas próprias mãos, as cores das pinturas feitas nos muros de Santiago durante a campanha de Salvador Allende. No entanto, estas pinturas, que estavam presentes "em todas os muros de Chile", como diz "Mono" González, o principal artista e desenhista dos murais, foram repintadas (apagadas) pelos militares.

O rastro está marcado por uma não-intencionalidade e, assim, mantém-se significante e, no caso, significado, para além de uma intenção imediata de significar. Os rastros não são criados - como são outros signos culturais e linguísticos -, mas sim deixados ou esquecidos. O gesto arqueológico que Guzmán articula em seu filme não só decifra a "singularidade concreta" do rastro, como também apresenta e busca compreender "o processo, muitas vezes violento, de sua produção involuntária" (Gagnebin, 2006:111). Se quem deixa rastros não o faz com a intenção de transmitir e de significar algo, quem os decifra deverá fazer esse caminho.

Gagnebin chama atenção para o poema "Apague os rastros", de Bertolt Brecht, que Benjamin analisa em "Experiência e pobreza". Nele Brecht estaria 
descrevendo de forma premonitória os mecanismo de abandono e de omissão da responsabilidade individual que os regimes totalitários do século $\mathrm{XX}$ iriam instaurar. A última estrofe: "Cuide, quando pensar em morrer/ Para que não haja sepultura onde jaz..." (Ibidem:116), nos remete aos corpos sem túmulos: mortos sem sepultura que, no século XX, com tantos massacres, guerras e genocídios, assim ficaram desde os armênios, passando desde as práticas nazistas que, ao perceberem a inevitável derrota na Segunda Guerra, retiraram os corpos em decomposição de valas comuns para serem cremados, até os desaparecidos políticos das ditaduras do Cone Sul e os eventos na ex-Iugoslávia e em Ruanda. Mas, em especial, no caso dos nazistas e das ditaduras latino-americanas houve a estratégia de aniquilação dos possíveis rastros que as ações criminosas provocaram.

Ao golpear a pedra e retirar a camada de tinta que oculta uma imagem do passado, Guzmán está abrindo também as cicatrizes que estão paradoxalmente abertas e ocultadas pelos acontecimentos violentos que o país viveu. Após fazer visível a pintura que antes era só um pequeno e pálido ponto azul, o diretor está, a partir desses vestígios, significando e apresentando um novo caminho possível da história. Aqui, a história é dirigida na contramão e estabelece a primazia da lembrança como contrapartida à amnésia: "O poder cresce no esquecimento, mas por trás da capa de amnésia que cobre o país, a recordação emerge, as memórias vibram na flor da pele."
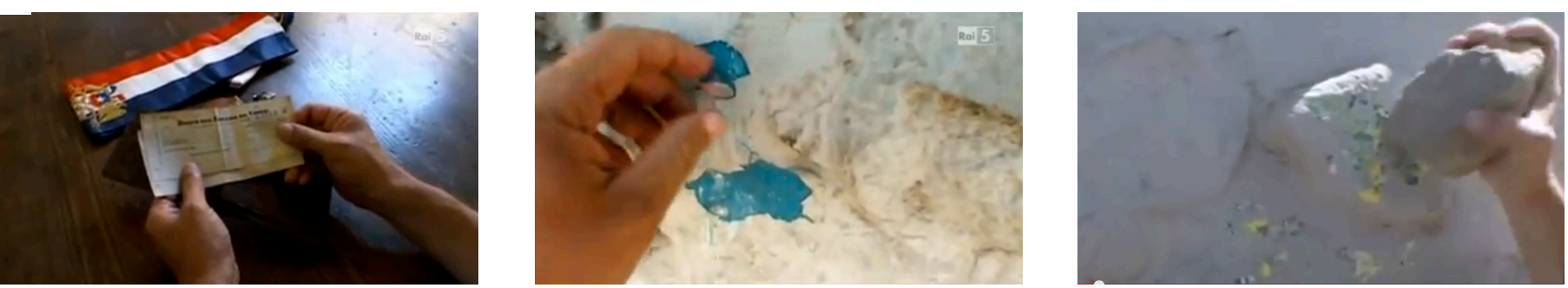

Figuras 32, 33 e 34: O gesto arqueológico de Patricio Guzmán em Salvador Allende.

Serão essas pessoas, como o artista "Mono" que "nunca esqueceu nada, nenhum detalhe da época de Allende", que ajudarão Guzmán reconstruir a figura de Allende. Além do testemunho delas, o filme continuará "operando para ancorar 
o gesto arqueológico em relação à criação de geografias alternativas que surgem do trauma do Golpe e da ditadura" (Sadek, 2013:40).

Como pudemos ver em $O$ caso Pinochet, a construção de geografias alternativas de Villa Grimaldi emerge a partir das memórias dos sobreviventes. Também será o caso em Nostalgia da Luz, quando o arquiteto Lawner refaz a planta baixa do centro de concentração de Chacabuco unicamente com as medidas que memorizou durante o tempo de detenção - tendo guardado de memória o número de passos que usou como medida.

Em Salvador Allende, Guzmán explica ter encontrado sua versão do Chile na obra da artista plástica Ema Malig. Nesta sequência, antes mesmo de ver o rosto de Ema, vemos suas mãos abrindo cuidadosamente uma carta endereçada a ela por Salvador Allende. Em seguida, Guzmán mostra a obra de Ema: um mapa gigante pintado em uma tela de pano esticado que representa o Chile de seu imaginário resultante do exílio, com terras e mares chamados: Errancia, Destierro, Naufragios e Vientos del Sur. Ele narra: "Quando descubro a pintura de Ema, vejo ali o Chile que eu vivo: uma terra fragmentada, ilhas à deriva que não se encontram."

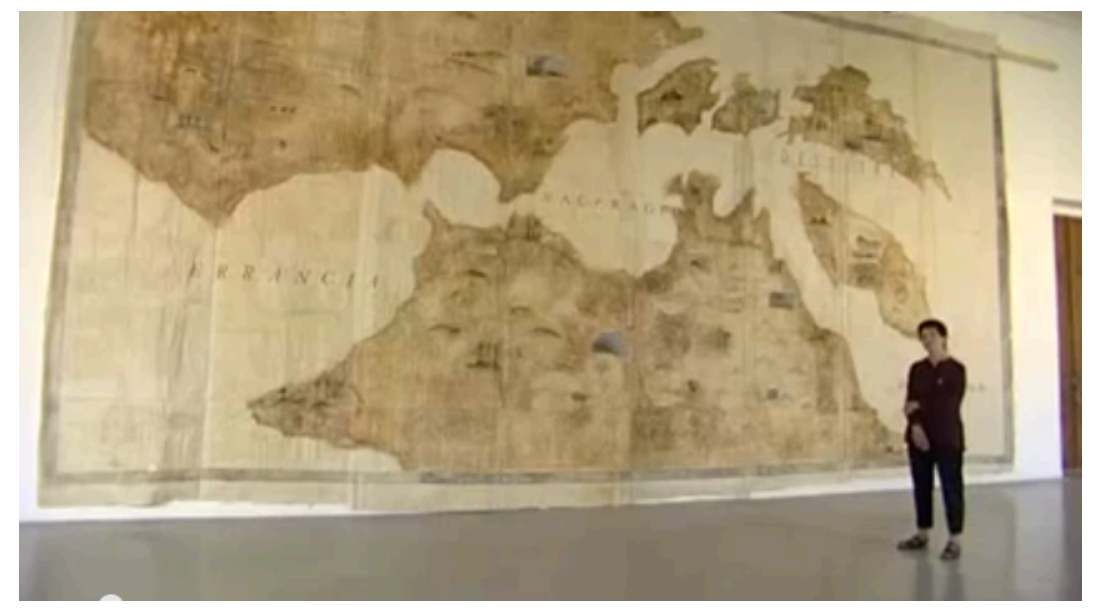

Figura 35: Ema Malig diante de seu quadro.

Em Nostalgia da Luz, o deserto de Atacama será esta "ilha à deriva" de um país "fragmentado". O território será o elemento para uma reflexão filosófica da relação das origens da vida (das origens do Chile contemporâneo), das memórias humanas e das estrelas. O documentário, ao sair do espaço urbano, isto é, de um espaço que está sempre afirmando seu tempo presente, irá, como diz Guzmán: 
"demonstrar a importância do passado e isso me levou ao deserto de Atacama, porque o deserto é o planeta do passado, tudo ali vem do passado" (Guzmán, 2012.a, s/n).

Luz, nostalgia e memória serão miragens dessa paisagem: pertencem ao passado, mas constantemente penetram o presente e a nossa percepção. A matéria e as memórias que existem no deserto serão as forças transformadoras que fazem convergir temáticas físicas e metafísicas, individuais e universais. As imagenscristais que o filme produz irão proporcionar um tempo não-cronológico, onde "o passado coexiste com o presente que ele foi”, em uma expressão deleuziana (Deleuze, 2007:103).

Nostalgia da Luz inaugura uma nova aproximação do passado do Chile. Diferindo de seus últimos documentários, em Nostalgia da Luz, Guzmán não elege figuras monumentais da história chilena como Augusto Pinochet e Salvador Allende. Dessa forma, ao não evocar diretamente estes personagens, o filme, sem perder sua carga política, nos convida para uma reflexão sóbria, com teor filosófico-existencial, onde história e ciência se articulam a partir das imagens do deserto de Atacama e dos estudos feitos por pesquisadores que frequentam essa região, no caso, sobretudo praticantes da Arqueologia e da Astronomia.

A voz em over de Guzmán ganha uma importância central na narrativa. Além de estar mais presente do que em seus filmes anteriores, ela será responsável por fazer as conexões entre os objetos estudados por estes saberes academicamente separados. Aqui, as temáticas metafísicas e físicas se aproximam, as histórias privadas se abrem para a coletividade. Assim, existe no documentário o que foi dito em outros:

(...) uma comunicação constante entre o que é do domínio privado e o que é do domínio público; o filme torna-se um espaço-tempo em que as idéias podem tomar forma como "bem comum"; pouco a pouco, extrai-se dos sofrimentos particulares de uma família e das questões em torno da identidade hoje o que é e deve ser compartilhado para que seja possível a formação de uma memória e de um destino comum." (Lins, 2004: 77).

Dessa forma, ao articular conexões entre histórias privadas - as suas próprias e as dos personagens que ele encontra no deserto - e assuntos amplos e universais, tais como o tempo, a memória e a permanência, o filme estaria 
realizando, como identifica Consuelo Lins, a propósito do filme Passaporte Húngaro (2003) de Sandra Kogut, uma nova forma de cinema político.

As primeiras imagens do filme são constituídas por planos fechados de um antigo telescópio alemão - ainda em funcionamento - em Santiago do Chile. No entanto, para um espectador leigo a respeito de maquinário astronômico, esse começo pode os remeter aos grandes sistemas de engrenagens de relógios tipo Big Ben. O tempo lento do funcionamento acompanha o distanciamento da câmera em relação ao objeto; pouco a pouco a estrutura metálica ganha novas dimensões e podemos afirmar, por fim, de que se trata de um telescópio. A cartela com o título do filme aparece. Em seguida, ainda nos encontramos dentro da cúpula fechada onde o telescópio se movimenta. O teto se abre e a luz do sol, extremamente forte, invade o ambiente, deixando a imagem branca pela superexposição. A trilha sonora formada por instrumentos de corda, que se inicia com a abertura do teto, intensifica ainda mais essa imersão de luz; imagens da superfície lunar aparecem em preto e branco, suas gigantescas crateras nos remetem a um cenário de pósdestruição; como se a corrida espacial e armamentista do período da Guerra Fria tivessem também deixado suas marcas ali (o que de fato aconteceu com as pegadas - eternizadas na ausência de ventos - dos astronautas e da bandeira norteamericana). A luz do sol que rebatia na lua, agora penetra pela janela de uma casa. Guzmán inicia sua narração explicando que os objetos dessa casa poderiam ser os mesmo de sua casa de infância, numa época em que "Chile era um remanso de paz, isolado do mundo. Santiago dormia ao pé da cordilheira sem nenhuma conexão com a Terra”. O diretor nos conta de sua paixão pela fícção científica e pelas estrelas enquanto as imagens internas de cadeiras e poltronas, dos cômodos e de um quadro da Santa Ceia, dão lugar à fachada externa desta casa provinciana. Ele narra: “o tempo presente era o único tempo que existia”. Após essa ultima frase uma espécie de pó cósmico sobrepõe pouco a pouco a imagem da fachada colorida; "um vento revolucionário nos lançou ao centro do mundo", aqui Guzmán se refere a eleição de Salvador Allende em 1970 e da atenção internacional dada ao Chile nesse momento. 


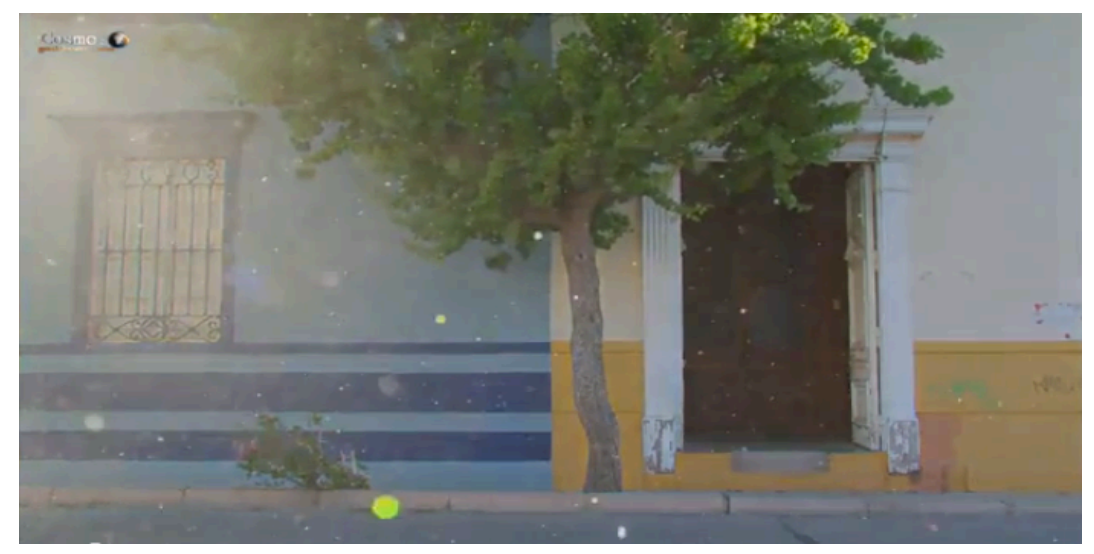

Figura 36: Efeito especial de 'pó cósmico' que se justapõe à imagem.

Nessa mesma época, astrônomos do mundo todo descobrem que no topo dos Andes, no deserto de Atacama, é "possível tocar o céu com as mãos”. Será através desses modernos sistemas de telescópios espalhados pelos diversos observatórios das altitudes dos Andes como La Silla, Paranal, Gemini e o mais recente ALMA, que as imagens das galáxias distantes podem ser captadas. No entanto, estas imagens vistas no presente já pertencem ao passado - vemos no presente o passado desses corpos estrelares como eram a milhões de anos atrás. Dessa forma, Guzmán comenta que o deserto de Atacama é uma espécie de "porta para o passado", no qual suas características geográficas e climáticas possibilitam esse olhar mais apurado para o que se passou: temos, por um lado, a transparência do ar e a altitude dos Andes como fatores essenciais para a observação astronômica e, por outro, devido sua localização remota, a instalação de campos de concentração pela ditadura de Pinochet e a ocultação de centenas de corpos pela região, sem talvez imaginar que o clima extremamente árido permitiria a conservação dos restos mortais de suas vítimas. E, por essa mesma razão, se tornou igualmente um local ideal para a prática arqueológica. Se o filme se apresenta como um espaço aberto do passado - constituindo uma espécie de arquivo -, também estamos tratando, naturalmente, sobre o resgate das várias memórias relacionadas a este lugar. Confirma Guzmán:

Eu acho que a vida é memória, tudo é memória. Não há tempo presente e tudo na vida é lembrar. Acho que memória engloba toda a vida, e toda a mente. Eu não sou simplesmente eu - eu sou o meu pai e também todos que vieram antes de mim, o que são milhões. Nostalgia da Luz surgiu a partir deste conceito. Trata-se 
de corpo e alma, mas também envolve a terra, os cosmos, tudo combinado. (Guzmán, 2012.b, s/p)

O tempo presente é sem dúvida o tempo modal mais escorregadio, pois sua existência se dá no choque entre o "passado", que não é mais, e o "futuro", quem vem se aproximando e, no entanto, ainda não o é (Arendt, 2010:227). O presente é o tempo destinado ao homem - ao Ego pensante. A percepção, como apontou Henri Bergson, acompanha uma carga impregnada de lembrança; o correr do tempo (durée), portanto, está sempre em via de manter ativo o passado e o presente, criando sua comunicabilidade e nossa capacidade de armazenar o passado como memória. A durée seria então a coexistência entre o passado e o presente. Podemos pensar que as imagens do deserto e das luzes das estrelas constituem um tempo sui generis, um tempo que não segue a lógica linear e que conseguem articular essa coexistência de temporalidades. $\mathrm{O}$ primeiro entrevistado do filme, o astrônomo Gazpar Galaz, exemplifica bem as questões sobre o tempo apontadas acima:

O presente não existe. Realmente, o único presente que existe é o que tenho em minha mente, digamos, em minha consciência. Esse seria o mais próximo do presente absoluto. Na verdade, nem isso, pois quando eu penso o sinal que passa entre meus sentidos tem uma duração. Quando eu digo "esse sou eu" e eu me toco, isso já tem um certo atraso.

A fala de Galaz demonstra o grande paradoxo do tempo, que também acaba sendo o grande paradoxo do cinema: a realidade que vemos a nossa frente, assim como a realidade que se apresenta na tela, já não existe. Tudo que vemos, tudo que se filma, faz parte do passado.

O passado se torna a ferramenta de trabalho para esses profissionais, o que inclui o próprio cineasta. Ao longo do filme, observamos, primeiro, o estudo do universo no qual astrônomos buscam suas respostas através das luzes e sons de bilhões de anos atrás, muito antes da existência do planeta. Em segundo lugar, está o estudo de um passado mais próximo, isto é, de nossas origens enquanto seres humano realizado por arqueólogos. E, ainda podemos destacar um terceiro movimento, que é o do próprio filme, no qual Guzmán pretende socializar essas questões traumáticas do passado chileno. 


\section{3}

\section{A socialização da memória "pré-história acusatória" do Chile}

A densidade histórica do deserto de Atacama desmente a semântica normalmente atribuída ao substantivo "deserto". Logo nas primeiras imagens do Atacama, Guzmán diz: "não há nada, não há insetos, não há animais, não há pássaros. Todavia, está cheio de história." A história chilena permanece, ainda, impregnada nesse território que não comporta mais vida animal. Existem perguntas, assim como fazem os astrônomo com relação às origens de seus objetos de estudos, que a história oficial igualmente não respondem (e, diferente daquela ciência, não querem responder).

Como vimos, é no deserto que esses movimentos de estudos sobre o passado se entrelaçam. Esse "livro aberto da memória" será explorado e construído por Guzmán pelos modos particulares de leituras do passado que cada campo científico realiza. $\mathrm{Na}$ astronomia o diretor deposita uma maior carga poética e abstrata em sua busca por respostas enquanto na arqueologia o processo de trabalho aparece como algo mais incômodo sob os pés de quem procura os vestígios, seja as marcas das extintas civilizações pré-colombianas seja as ossadas mais recentes dos mortos ali enterrados. Ainda que preocupadas com elementos distintos, essas formas de leituras - das ciências voltadas para uma reconstrução do passado -, somadas à carga de subjetividade que Guzmán insere desde o início do documentário, possibilitam o espectador fazer conexões entre as esferas científicas e as pessoais (por exemplo, a experiência de Guzmán quando criança e sua paixão pela astronomia). Na primeira meia hora do documentário, aprendemos que os arqueólogos dessa região buscam rastros de civilizações antigas e terminam trabalhando muitas vezes com o que, segundo nos diz o arqueólogo Lautaro Núñez, seriam elementos ou provas para se fazer uma "pré-história acusatória" do Chile. O que inclui suas épocas extrativistas vinculadas ao salitre e ao cobre, especialmente no século XIX onde, como nos informa Guzman em off, "a mineração era como a escravidão". Em determinado momento da entrevista, Núñez mostra cumplicidade com Guzmán; quando este começa a lhe formular uma pergunta, Núñez sorri na direção do diretor e bebe um gole de café, como que esperando aquela pergunta. Ele, em sua resposta, corrobora a preocupação que o diretor tem diante da amnésia guiada pela história oficial, do processo ativo de 
esquecimento feito por ela; em última instância, da manipulação da memória que foi operada por meio das relações sociais marcadas pela ideologia da época. Núñez segue sua resposta:

É um paradoxo que o passado mais próximo de nós se mantém encapsulado (...) quantos segredos nós guardamos do século XIX, nunca foi dito com clareza por que marginalizamos nosso indígenas. É praticamente um segredo de Estado (...) pouco procuramos entender porque no século XIX geramos tantos modelos econômicos vertiginosos como o salitre mas que hoje não sobrou nada. Então, as nossas histórias mais próximas tivemos mantidas em um nível de ocultação, de encobrimento. É um absurdo, nós não querermos estar próximo a essa pré-história recente; que seria quase uma pré-história acusatória. E isso, meu amigo, não ajuda ninguém. Nem a direita, nem ao centro, nem a esquerda.

Tzvetan Todorov em texto sobre os "Abusos da Memória" afirma que "os regimes do século $\mathrm{XX}$ revelaram a existência de um perigo antes inesperado: a supressão da memória" (Todorov, 2000:11). A memória e, consequentemente, a História se tornaram objetos de disputa das relações de poder na realidade social. A memória é, portanto, uma maneira de legitimar e reorganizar o imaginário da sociedade. Como diz Jacques LeGoff:

Tornarem-se senhores da memória e do esquecimento é uma das grandes preocupações das classes, dos grupos, dos indivíduos que dominaram e dominam as sociedades históricas. Os esquecimentos e os silêncios da história são reveladores desses mecanismos de manipulação da memória coletiva (LeGoff, 1990: 426).

Uma das questões políticas e éticas mais importantes com que se enfrentam as sociedades durante a transição de um governo autoritário para outro democrático é como se posicionar frente ao passado repressivo, realizando o trabalho de memória sobre as injustiças sofridas. A forma vista para o combate do legado autoritário se dá por meio de anistias, julgamentos, estabelecimentos de Comissões da Verdade, compensações financeiras e gestos simbólicos como a construção de monumentos e a proclamação de dias comemorativos. No entanto, é tido pela historiografia, que o processo de transição democrático no Chile foi uma das experiências mais pactuadas da América Latina: “As leis de anistia herdadas, como no caso do Brasil e Chile, ou as limitações constitucionais sobre a ação do governo, como no Chile, podem criar obstáculos para a atribuição de responsabilidades" (Barahona de Brito, 2002:46-47). A continuidade de enclaves 
autoritários estabelecidos pela Constituição de 1980, por exemplo, permitiu ao general Augusto Pinochet exercer o cargo de Comandante-Chefe do Exército até março de 1998, além de impedir a investigação ampla das violações de direitos humanos (Vasconcelos, 2013).

Se na cidade neoliberal, como Santiago do Chile, a transparência é ilusória, nela se assistiu uma "democracia protegida" durante sua transição; o transparente e desértico ar, por sua vez, revela as origens do "frágil" presente do país. Guzmán lança seu questionamento sobre a memória oficial que permanece e acaba sendo coniventes com discursos positivos sobre a ditadura. Como bem aponta Alexandra Barahona de Brito:

Os mitos históricos e a memória oficial definem o âmbito e a natureza da ação, reorganizam a realidade e legitimam os detentores do poder. Se convertem em parte do processo de socialização política, influenciando a percepção da realidade e na assimilação de ideias e opiniões públicas (Barahona de Brito, 2002:69).

Dessa forma, as memórias históricas - a história oficializada que é ensinada nas instituições de ensino, por exemplo - e as recordações coletivas podem ser instrumentos para legitimar discursos, criar lealdades e justificar opções políticas. A versão hegemônica que se cria de um passado estimulam as sociedades de elegerem o que se deve recordar e o que se deve esquecer e, de alguma forma, já condiciona a maneira que se operará suas opções futuras. Em uma entrevista dada dois anos antes do início da produção de Nostalgia da Luz, Guzmán disse que o documentário seria: "Um filme centrado no Chile atual, esse país moderno que acredita estar no melhor lugar da América Latina, que tem um nível de crescimento muito alto, mas onde as desigualdades são também enormes” (Guzmán, 2008: s/p).

Essa questão da economia neoliberal atual não está explicitamente presente no documentário, no entanto, ao apontar para a temática do minério - e futuramente mostrando que esses locais abandonados foram reapropriados na década de 70 para servirem de campo de concentração - o filme "amplia o alcance temporal e temático da memória relacionando-a com a exploração capitalista das épocas extrativistas que constituem a base onde se lançaram os cimentos do Chile moderno" (Sadek, 2013:51). 
Ao ampliar nosso conhecimento, renovando os significados desses espaços aparentemente isolados e sem vida, o diretor faz um movimento para uma socialização dessa história que o deserto guarda, dessa "pré-história acusatória" que reflete muito do que existe no presente do país.

\section{4}

\section{Luís Henríques e Miguel Lawner, os transmissores da história}

Chacabuco fica a $100 \mathrm{~km}$ de Antofagasta, a principal cidade da região norte do Chile. Foi uma importante fábrica de salitre que começou a funcionar em 1924 comportando uma população de 5.000 trabalhadores. Em 1971, após o término das atividades de exploração em 1940, Allende declarou o local como monumento histórico nacional. No entanto, em novembro de 1973, Chacabuco se tornou o maior campo de concentração do regime de Pinochet. As instalações do local que no passado serviram ao mineradores, foram reapropriados pelos militares. Com a intenção de desencorajar qualquer tentativa de fuga dos prisioneiros políticos foram instalados cabines de vigilância, arames farpados e minas terrestre (que até hoje permanecem enterradas).

Com 32 minutos de filme, após uma sequência na qual técnicos especializados trabalham na reparação do maquinário de um observatório de alta tecnologia, vemos um homem olhando as estrelas a olho nu, com a ajuda de um simples instrumento de medição. Essa imagem inaugura a sequência sobre o campo de concentração de Chacabuco. Ainda não sabemos quem é o homem que opera o rústico objeto, nem que estamos no solo do que um dia foi o campo de concentração. A cena do presente sofre um corte temporal; vemos, em seguida, uma filmagem aérea antiga do lugar (uma das poucas imagens de arquivo em movimento no filme). A montagem de Guzmán apresenta uma espécie de contraplano: se antes víamos as estrelas da Terra, agora são elas que nos veem do universo, como se os corpos estrelares fossem testemunhas mudas de nossa história. 
O homem retorna novamente - vemos em um plano fechado os dedos dele percorrer um mapa com as constelações enquanto ouvimos sua voz falando sobre as aulas ilegais de astronomia que ele e um grupo de presos tinham com um médico que conhecia um pouco do assunto. A figura de Luís Henríquez resgata os restos materiais da história de Chacabuco; o lugar é uma dupla ruína: o campo foi construído sobre a ruína de uma mina e, hoje, é a ruína de um campo de concentração.

A arqueologia fílmica existente em Nostalgia da Luz tem a capacidade de recuperar práticas espaciais capazes de ativar a memória e de construir as ferramentas necessárias de combate à lógica ditatorial e de esquecimento que a transição política manteve. A prática arqueológica, já presente em seus outros filmes, ganha novos contornos agora. Além de tornar a arqueologia um tema central de seu filme, ao entrevistar um arqueólogo e filmar as pinturas précolombianas dos nômades do deserto, Guzmán mostra como essa prática é uma condição de resistência - e mesmo de sobrevivência - da memória para algumas pessoas, como veremos mais adiante.

O gesto arqueológico está presente nessa visita à Chacabuco. Luís mostra primeiro como foi construído o instrumento de medição que possibilitou aquele grupo de presos estudarem o universo; a observação das estrelas eram para eles como sua "liberdade interna". Luís caminha pelas ruínas, "relembra das coisas que foram apagadas, os cabos de eletricidade, as torres de vigilância”. Dentro de uma das celas, ele localiza os nomes de seus companheiros escritos numa parede. Apesar de incompletas ele consegue reconstituir a maioria dos nomes e sobrenomes.

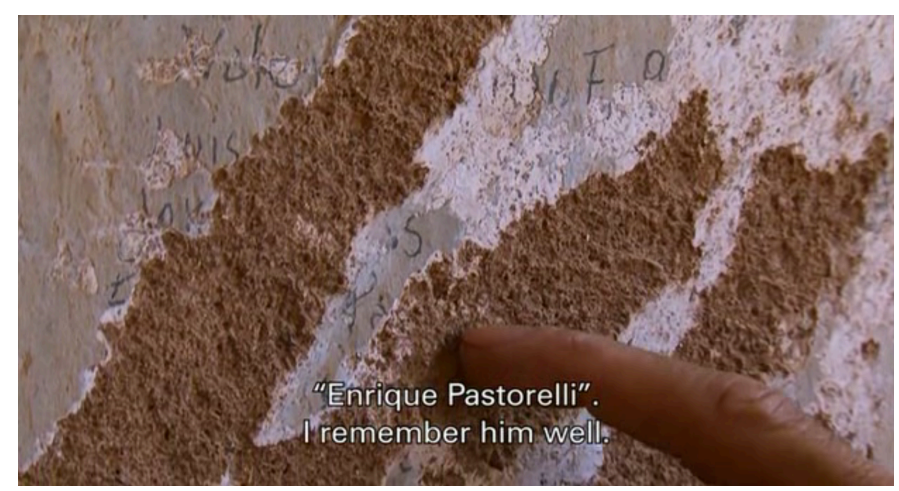

Figura 37: Luís Henríquez recorda os nomes dos presos políticos em Chacabuco. 
Luís Henríquez desafia o apagamento dos rastros. Os elementos residuais vivem numa constante fragilidade, sob a ameaça de serem apagados ou não mais reconhecidos como indicou Jeanne-Marie Gagnebin, no entanto, ao conseguir localizá-los e ressignificá-los, como faz Luís, se torna possível construir uma história voltada contra os agentes de destruição. "A categoria do rastro inspira a reconstrução constante do ato de narrar, conferindo ao detalhe, ao resto, um papel constitutivo do passado" (Ginzburg, 2012:115). Guzmán constrói sua narrativa a partir desses elementos fragmentários - sejam eles materiais como os ossos, as estruturas de Chacabuco e as fotografias, sejam eles imateriais como a luz, a memória e os sons provenientes do espaço - fraturando a linearidade do tempo "em favor da evocação de um tempo libertário" (ibidem).

A sequência termina com planos de Luís andando pela parte externa do campo, no pôr do sol. Ouvimos em over: "Luís é um transmissor da história". Após alguns segundos, um pó cósmico aparece, pela segunda vez no filme, se sobrepondo ao plano. Esse efeito inicia a transição para a próxima sequência, estamos agora na sala do arquiteto Miguel Lawner. Esse pó cósmico pode ser pensado como a própria memória dessa história que se perpetua pelos fragmentos, que vaga pelo tempo e que consegue ser apreendida por essas pessoas. Guzmán define Lawner como o "arquiteto da memória" - durante sua prisão por cinco centros de detenção diferentes, Lawner desenvolveu uma técnica para memorizar com exatidão as medidas do locais em que passou. O filme vai resgatar esse "ato de memória corporalizado" (Rodríguez, 2007) que possibilitou Lawner guardar na memória o máximo de detalhes. Vemos os pés dele caminhando pelo escritório: ele conta seus passo de uma parede a outra, repetindo o procedimento em cada recinto que passa. Foi dessa forma que ele conseguiu calcular a escala dos lugares e, após chegar no exílio na Dinamarca, reproduzir as plantas baixas dos campos e desenhar com uma riqueza de detalhes as cenas de tortura que ele testemunhou.
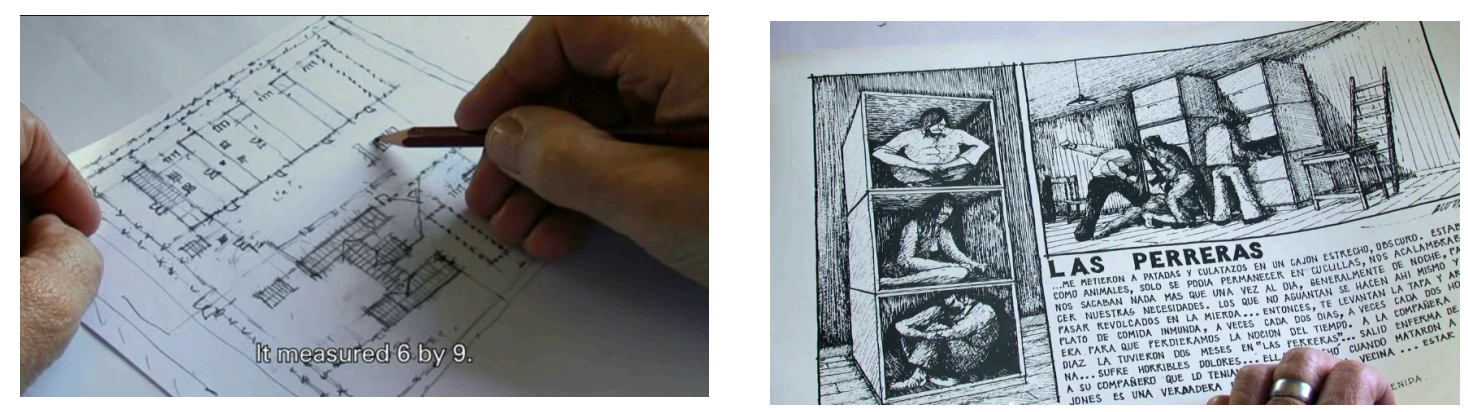
Figuras 38 e 39: Exemplos de uma planta baixa e de um desenho das técnicas de tortura mostradas no filme.

Tanto Lawner como Luís Henríquez conseguem ser transmissores da história porque são capazes de narrar e compartilhar suas experiências de vida. Eles estariam desafiando a tese de Benjamin, em um momento que as novas dinâmicas do mundo capitalista moderno se impõem, sobre o fim da narrativa pura, tradicional, isto é, da dimensão oral como transmissora da experiência de um ser humano para outro. Ambos estão resgatando no presente suas memórias e as organizando através do testemunho, de modo que formam, junto ao filme, uma experiência coletiva (Erfahrung).

Por fim, como sempre diz Guzmán em suas entrevistas, o Chile é um país que não cultiva sua memória. Nos últimos planos vemos Lawner e sua mulher de costas, ouvimos em over: "Miguel e sua esposa são, para mim, como uma metáfora sobre o Chile: ele é a recordação enquanto Anita, por causa da doença do Mal de Alzheimer, é o esquecimento." Nostalgia da Luz é a prova desta complicada encruzilhada que a história vive, de um Chile próspero, em crescimento, e sua pobre memória.

\section{5}

\section{Imagens cristalinas, corpos estrelares}

As mulheres de Calama, no deserto de Atacama, aparecem tardiamente no filme. No entanto, a presença desse grupo de mulheres, que buscam até os dias de hoje os ossos de seus familiares desaparecidos, produz um efeito ainda mais unificador que o documentário vem articulando entre os campos da astronomia e da arqueologia. Isso vai se dar no momento em que Guzmán vai aproximando as pistas sobre a equivalência entre a identidade molecular dos ossos e das estrelas, porque são ambos feitos de cálcio. 
Uma nova dimensão que podemos perceber com a entrada desse novo grupo social é o fato de nos confrontarmos com um problema que continua a existir no país, isto é, se em alguma medida Lawner e Luís conseguiram conciliar e viver com suas lembranças, as imagens de mulheres buscando ossos de seus maridos, irmãos e filhos demonstram que, para outros, o passado ainda é uma ferida profundamente aberta e que precisa de respostas.

A forma como Guzmán vai apresentá-las no filme é interessante. Ele começa apresentando Víctor, um jovem astrônomo de 29 anos, que trabalha no projeto ALMA, que na época do filme ainda estava em fase de construção. Ele estuda as ondas sonoras captadas pelas 60 antenas desse radiotelescópio, são os sons de estrelas "cuja a luz não chega à Terra". Ficamos sabendo que ele é "filho do exílio" e que sua mãe o incentivou estudar astronomia quando era garoto na Alemanha. Víctor se define como "fillho de nenhuma parte", nem chileno, nem do país que veio. No entanto, quando Guzmán lhe pergunta se ele se sente bem aqui (no meio dessa paisagem isolada, a 5.000 metros de altitude), ele lhe responde que sim, e completa: "eu me sinto chileno". O deserto, podemos pensar, além de local de trabalho se transformou em um espaço terapêutico para ele. Em seguida, vemos sua mãe fazendo massagem em uma mulher; assim como o deserto, ela exerce uma função terapêutica: a mãe de Víctor se dedica a ajudar ex-prisioneiros que foram torturados. Será através dela, uma figura que busca apaziguar os traumas, que ouviremos pela primeira vez sobre o grupo de mulheres.

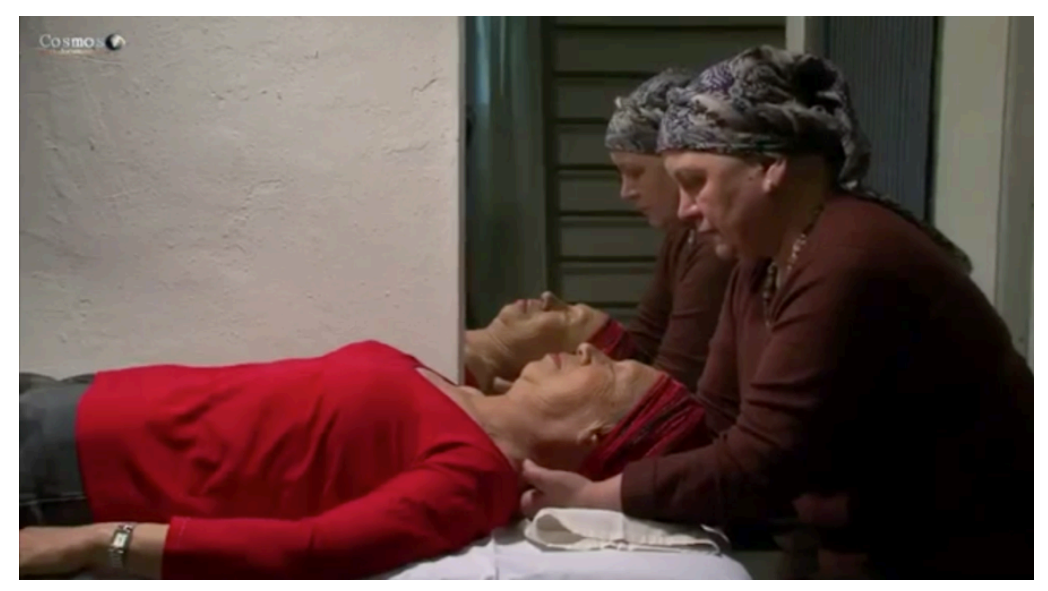

Figura 40: Mãe do jovem engenheiro Víctor tratando uma ex-torturada e seu reflexo no espelho. 
Se o filme opera em suas imagens essa dualidade entre o presente e o passado, esse plano talvez seja o mais evocativo para trazermos o conceito de imagem-cristal de Gilles Deleuze, desenvolvidas a partir das ideias de tempo e memória de Henri Bergson. A imagem-cristal surge justamente de uma conjugação da imagem que é no mesmo instante atual e virtual. Em outras palavras, sua operação fundamental é que o passado não se constitui depois do presente, cronologicamente, mas ao mesmo tempo. Como Deleuze nos diz: "O passado não sucede ao presente que ele não é mais, ele coexiste com o presente que foi. O presente é a imagem atual, e seu passado contemporâneo é a imagem virtual, a imagem especular" (Deleuze, 2007:99).

Esta imagem especular estaria nessa constante dualidade, um reflexo que leva os objetos e suas memórias a um ponto de indiscernibilidade. Deleuze traz o espelho como exemplo dessa estrutura cristalina, onde o real e o imaginário, o presente e o passado, o atual e o virtual habitam mutuamente.

Em termos bergsonianos, o objeto real reflete-se numa imagem especular tal como no objeto virtual que, por seu lado e ao mesmo tempo, envolve ou reflete o real: há "coalescência" entre os dois. Há formação de uma imagem bifacial, atual e virtual. (Deleuze, 2007:87-88)

No filme, ouvimos em over: "Uma comissão oficial determinou que há 30.000 ex-torturados no Chile. Mas se estima que há outros 30.000 que não foram declarados." Aqui está precisamente a coalescência do atual (a comissão oficial) com o virtual (a estimativa). Para cada ex-torturado que esta nesta lista existe um reflexo seu, uma imagem opaca de seu outro, pois "a imagem atual também se torna virtual, por seu lado, remetida a outra parte, invisível, opaca e tenebrosa, como um cristal que mal foi retirado da terra" (Deleuze, 2006:90).

A cristalização entre o atual e o virtual está dentro do cinema que Deleuze chama de imagem-tempo, ou seja, diferentemente da leitura que faz do cinema imagem-movimento, no qual a narração é baseada em uma organização racional do tempo e do espaço (esquema sensório-motor), sua dinâmica quebra com esse sistema de representação ao confrontar diretamente nossa percepção do tempo. Seu princípio não se estrutura na cronologia, mas no seu desmantelamento, que revela o tempo entendido somente como mudança, deslocamento, a pura casualidade que Bergson descreve como duração (durée). Dessa forma, Matéria e 
memória (1986) de Bergson, antecipou as temporalidades múltiplas e as durações superpostas; "interessam-no [a Deleuze] as formas como cinema pode transmitir "lâminas de tempo" múltiplas e contraditórias", disse Robert Stam (2006:284). A imagem-cristal oferece as operações fundamentais do tempo como uma fronteira instável e inapreensível entre o passado recente, que não é mais, e o futuro imediato, que ainda não é. "A organização panorâmica do espaço perde sua força e cede lugar à tela entendida como memória palimpséstica" (Stam, 2006:287). O termo "memória palimpséstica" trazido por Stam é interessante para pensarmos como essas imagens-cristais do deserto reorganizam e atualizam a matéria e as memórias remanescente que são percebidas no presente. Esta leitura palimpséstica é tanto a feita por arqueólogos como pelo próprio filme, justamente por aprofundar as camadas de leituras sobre as memórias que o deserto conserva. Dessa forma, "a memória se enraíza no concreto, no espaço, no gesto, na imagem, no objeto", arremata Pierre Nora (1993:9).
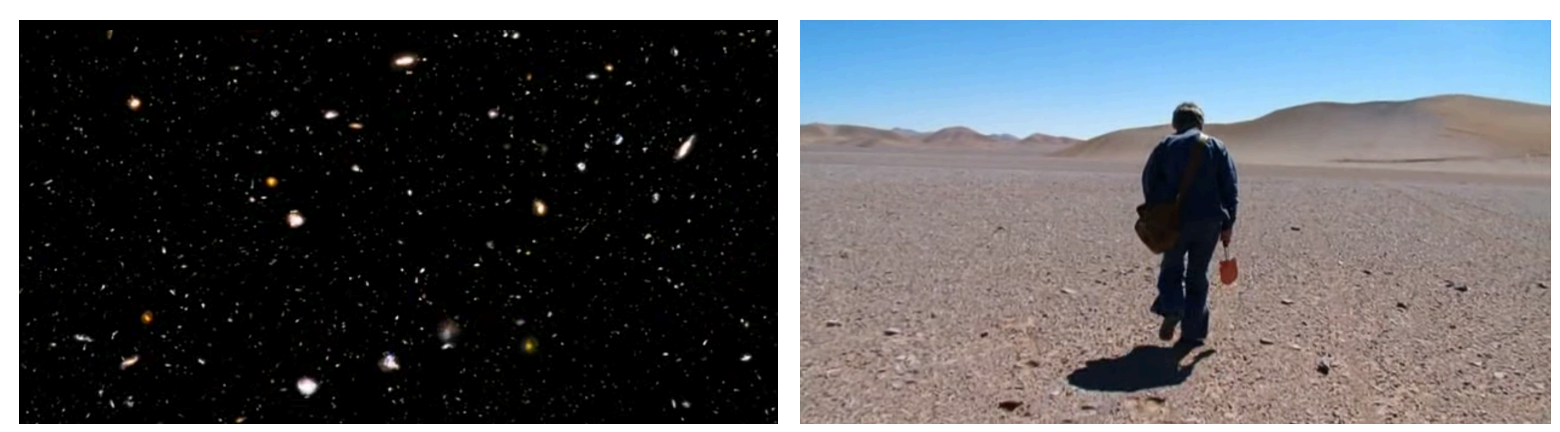

Figuras 41 e 42: Aproximação feita entre a imensidão do Universo e do deserto de Atacama.

A função da profundidade de campo presente na fotografia de Nostalgia da Luz é explorar justamente essas regiões do passado. Temos imagens de imensas planícies, vemos quilômetros de distância sem perder nenhuma nitidez. Mesmo os planos extremamente fechados de elementos como pequenos ossos, acabam por ganhar uma dimensão planetária, pois sua superfície magnificada pela lente da câmera nos remete a grandes corpos estrelares como que espalhados pelo deserto. Assim,

... as imagens em profundidade expressam regiões virtuais do passado, camadas de passado coexistentes, que tornam possíveis as imagens-lembrança; sua função principal é exibir o tempo por ele mesmo: uma função de rememoração, de temporalização, uma temporalização que se dá pela memória (Machado, 2010:280). 
Serão nesses planos abertos em profundidade que veremos muitas vezes as mulheres de Calama procurando os resquícios de seus familiares. Essa paisagem revela o passado, ao mesmo tempo que a esconde.

O ar é extremamente puro e você pode ver tudo muito claramente, mas ao mesmo tempo isso pode ser muito distorcido. Por exemplo, você pode ver um vulcão que parece perto, mas na verdade ele está a 80km de distância" (Guzmán, 2011.b, s/p).

O trabalho arqueológico dessas mulheres se torna um trabalho de uma vida toda - alguma delas já procuram corpos desaparecidos há mais de 30 anos. O astrônomo Galaz, ao comentar esse árduo trabalho das mulheres, faz uma comparação:

Eu posso imaginar que minha mãe ou meu pai se encontram no espaço, perdidos em algum lugar da galáxia. Eu estaria procurando com os telescópios. Eu ficaria completamente ansioso, pois o espaço é tão grande que encontra-los seria quase impossível.

Após essa fala, Guzmán faz uma montagem mostrando primeiro uma imagem do universo para em seguida cortar para um plano de uma mulher em atividade no deserto. Essa montagem sugere a impossibilidade de se vir a encontrar os cadáveres dos desaparecidos políticos, principalmente quando os que fizeram desaparecer não se pronunciam acerca da localização e dos procedimentos de ocultação desses corpos.

\section{8}

\section{“Talvez muitos dirão, para que queremos ossos..."}

A primeira sequência que vemos uma dessas mulheres se inicia após a conversa com a mãe de Víctor em sua cozinha. Ao longo de toda essa sequência, que é intercalada com as entrevistas de Galaz e do arqueólogo Nuñez, não veremos os rostos frontalizados delas. Guzmán parece querer, antes de particularizar seus sofrimentos pelo testemunho, apresentá-las como um problema social, amplo e coletivo. O plano inicial mostra somente uma mão escavando a 
terra com uma pequena pá, em seguida, a escala do enquadramento aumenta, a mulher com a pá se encontra de joelhos numa planície gigantesca. Esse procedimento se repete quando um plano com três mulheres escavando o solo é cortado para um ainda mais aberto mostrando que na realidade existem seis delas trabalhando.

Vicky Saavedra é uma dessas mulheres. Ela nos mostra pequenos fragmentos de ossos que possivelmente pertenciam aos braços de alguém. Nuñez nos conta que esses pequenos fragmentos, que pouco a pouco foram sendo encontrados por essas mulheres, serviram de provas comprobatórias de que os corpos foram removidos da terra e levados a outros locais, ou mesmo jogados ao mar, para que eles definitivamente não fossem encontrados. As retroescavadeiras militares partiram os esqueletos; tornaram o processo de identificação ainda mais complicado - um mesmo indivíduo tem agora seus ossos espalhados pelo planeta.

É o que ocorreu com Vicky ao procurar o corpo de seu irmão. Ela nos conta as partes que encontrou: um pé que estava dentro de seu sapato, uma parte de sua mandíbula, da testa, do nariz e o lado esquerdo de seu crânio.

O historiador Enrique Serra Padrós aponta que a política de desaparecimento foi o método de Terror de Estado (TDE) que se impôs com maior impacto e eficiência. $\mathrm{O}$ autor expõe como elementos componentes da metodologia do desaparecimento as seguintes ações:

a) sequestro ou detenção ilegal;

b) privação de liberdade;

c) execução de ações por agentes estatais, de forma aberta (policias e militares) ou encoberta (serviços de inteligência); também por grupos violentos de extrema direta sem vinculação oficial com o Estado mas agindo sob suas ordens e proteção;

d) ocultação do local de confinamento e da situação da vítima, pelas autoridades, simultâneo à negação de que aquela estivesse sob sua custodia;

e) ocorrência de homicídio estando a vítima detida pelo vitimário; 
f) ocultação do cadáver e de qualquer informação a respeito dos acontecimentos envolvendo a execução ou morte sob tortura da vítima. (Padrós, 2007:112) ${ }^{26}$

O desaparecimento do corpo é fundamental no desfecho dessa metodologia, pois a impunidade que se perpetuou após o fim das ditaduras se baseou na premissa básica de que se não há corpo, não há vítima e, consequentemente, se não há vítima, não haveria crime algum.

Hannah Arendt comenta, sobre a ausência dos corpos no contexto dos campos de concentração nazistas: "roubaram da morte o significado de desfecho de uma vida realizada." E ainda: "roubaram a própria morte do indivíduo, provando que, doravante, nada - nem a morte - lhe pertencia e que ele não pertencia a ninguém. A morte apenas selava o fato de que ele jamais havia existido" (Arendt, 1989:503).

Sem um corpo, sem a possibilidade do sepultamento, não se via - e nem se fazia ver com a carga simbólica efetiva que é um funeral - a indignação entorno das vítimas. Ainda, a falta do corpo gera incertezas - o desaparecido está vivo ou morto? Fugiu ou está exilado? Mesmo quando, após as incertezas iniciais, se aceita a irreversibilidade do desaparecimento, o problema se estende. A falta, por exemplo, de um atestado de óbito impede, para os esposos, a mudança de estado civil e impossibilita, para os filhos, a abertura para os trâmites de heranças. ${ }^{27}$

A procura pelos ossos dessas mulheres do deserto demonstra que elas necessitam ainda realizar o luto pela morte de seus parentes. A falta de esclarecimentos dessas execuções extrajudiciais...

...desumaniza a experiência de viver e a falta de resposta, caso a caso, torna a incerteza uma ferida permanentemente exposta. A privação da morte impacta a memória, e a suspensão indefinida do luto age sobre o esquecimento e o anestesiamento individual e coletivo resultantes (Padrós, 2007: 117).

\footnotetext{
${ }^{26}$ Esse artigo é uma adaptação sintética do capítulo 7 (A Política dos Desaparecimentos e o Terror de Estado) de sua tese Como el Uruguay no hay. Terror de Estado e Segurança Nacional. Uruguai (1968-1985): do Pachecato à Ditadura Civil-Militar, defendida junto ao PPG-História/ UFRGS, no final de 2005.

${ }^{27}$ No Brasil, a partir de 1995 houve certa mudança na postura oficial com a aprovação da Lei 9.140, a qual passou a reconhecer como sinônimo de desaparecido o termo morto oficial, o que, na prática, significou o reconhecimento público da morte, pelos órgãos repressivos estatais, de pessoas presas.
} 
O processo de luto não realizado ou incompleto tornam a tortura de outrora em uma tortura permanente. Vicky nos relata sua experiência como enlutada, na noite seguinte ao encontrar e levar para sua própria casa o pé de seu irmão:

Naquela noite, eu me levantei e acariciei o pé dele e tinha um cheiro de decomposição. Ainda estava dentro da meia. Uma meia vermelha, um vermelho escuro. Eu tirei da bolsa, fiquei olhando para ele. Eu fiquei na sala de estar por muito tempo. Eu tinha a mente totalmente vazia. Eu não tinha capacidade de pensar nada, de tão impactada que eu estava. No dia seguinte meu marido saiu para trabalhar e eu passei toda a manhã com o pé do meu irmão. Estávamos nos reencontrando. Foi um grande encontro e também uma grande desilusão porque, naquele momento, eu tive consciência de que meu irmão estava morto.

Violeta Berríos, por sua vez, segue sem encontrar nenhum vestígio de seu marido. Berríos, que na época do filme se encontrava com 70 anos, diz para Guzmán: "Enquanto eu tiver forças, se nós precisarmos continuar procurando, eu vou continuar." Sua procura, assim como seu testemunho, representa a tentativa de lutar pela memória de seu marido. A experiência da morte é incomunicável, não tem como ser transferida. A condição de luto, a vivência da dor da perda, é um processo social necessário para que a morte possa ser encarada e experimentada socialmente. O ritual fúnebre - muito estudado por antropólogos e arqueólogos - é um sistema que transpassa a história das civilizações humanas pois compartilha de uma crença comum: "a morte não é jamais o aniquilamento total do homem, ela é uma passagem para outra vida" (Rodrigues, 2010:6). Os ossos de seu marido são sua esperança para que ela mesma consiga realizar sua própria passagem, como fica claro na frase dela que leva o título desse subcapítulo, e, principalmente, quando diz: “se eu encontrá-lo hoje e me disserem 'amanhã você vai morrer' eu partirei feliz, feliz.” Além do desejo praticamente impossível de encontrar a ossada completa dele, ela nos conta seu sonho: "eu adoraria que os telescópio não olhassem só o céu, mas também que vissem através da terra para poder encontrálos." Na sequência seguinte vemos Galaz caminhando por uma estrada que liga os observatórios. A noite se aproxima, o astrônomo do alto da montanha, observa o pôr do sol lá embaixo. É como se esse corpo estrelar, tido como Deus supremo pelas culturas pré-colombianas que viveram na região, estivesse entrando por debaixo da terra. 


\section{9}

\section{Nostalgia reflexiva e o deserto como arquivo}

O deserto que Patricio Guzmán filma expressa os sonhos dessas mulheres, conserva o cálcio dos ossos e evoca um passado que parece incrustado em seu solo. No entanto, esse passado que sempre está em via de atualização não pertence unicamente aos objetos e a amplitude do Atacama; o filme é uma ação do próprio cineasta em atribuir memórias pessoais àquele espaço. Existe uma dimensão nostálgica no documentário, principalmente quando ele articula a astronomia com o próprio relato de sua vida: "Eu amava os contos de ficção científica, os eclipses da lua e olhar o sol através de um pedaço de vidro escuro". Esse tempo de inocência, onde a apreensão do mundo se construiu através das aventuras dos livros, já havia sido explorada por Guzmán em documentários como La Isla de Robinson Crusoe (1999) e Mi Jules Verne (2005), nos quais o teor político abre caminho para um tempo mais mítico e nostálgico.

A condição de exilado - podendo ela ser voluntária ou forçada -, uma condição que Guzmán viveu por mais de duas décadas, estimula a reflexão do próprio sujeito diante de sua tristeza pelo afastamento de sua pátria ou terra natal. "As histórias de imigrantes são as melhores narrativas sobre nostalgia - não somente porque eles sofrem devido à nostalgia, mas também porque eles a desafiam" (Boym, 2007:16).

Svetlana Boym em seu livro The Future of Nostalgia $(2001)^{28}$ vai traçar as origens e significados da noção de nostalgia que existe nos dias de hoje e analisar como que, segundo ela, o século XX começou com utopia e terminou com nostalgia.

A palavra "nostalgia" é formada a partir de duas raízes gregas, nostos significando "volta para casa" e algia "dor". Dessa forma, nostalgia seria um sentimento de perda e distanciamento, mas também, como aponta a autora, um romance com nossas próprias fantasias. O primeiro ponto crucial que ela destaca é que nostalgia não é “antimoderna”, isto é, ela não se opõem à modernidade, mas é contemporânea a ela. Nostalgia não seria somente uma expressão pela falta de um

\footnotetext{
${ }^{28}$ Vou usar para as citaçoes o ensaio da autora Nostalgia and Its Discontents (2007) que é uma adaptação de seu livro, mesmo sendo mais sucinto o texto consegue abordar todos os pontos importantes do livro além de dialogar com objetos mais atuais como o filme Adeus Lenin (2003) de Wolfgang Becker analisado por ela.
} 
lugar, mas o resultado de um novo entendimento do tempo e do espaço que torna possível a divisão entre "local" e "universal" (Boym, 2007:8). Isso nos leva ao segundo ponto: nostalgia parece ser a saudade por um lugar, mas é, na verdade, o desejo por um tempo diferente - o tempo de nossa infância, por exemplo. Em um sentido amplo, nostalgia é uma revolta contra a ideia moderna de tempo, do tempo da história e do progresso. Esse é um tempo que pode ser visto em Nostalgia da $L u z$, mesmo os gigantescos e modernos telescópios se movimentam lentamente enquanto seus processadores digitais calculam matematicamente milhões de dados, muitas vezes, demorando anos para chegar a alguma conclusão definitiva. O terceiro e último ponto é que nostalgia não é sempre retrospectiva, ela pode ser prospectiva também. "As fantasias do passado, determinadas pelas necessidades do presente, têm um impacto direto nas realidades do futuro" (Boym, 2007:8).

Além disso, será através da distinção feita por Boym de dois principais tipos de nostalgia (a restaurativa e a reflexiva) que irei compreender a nostalgia que Guzmán cultiva no filme. A nostalgia restauradora (restaurative) se preocupa em restaurar o passado como tradição e verdade - a autora localiza que esse tipo seria responsável pelo avivamento dos movimentos nacionalistas e do fundamentalismo religioso -, de fato, esse tipo de nostalgia não pensa ela própria como nostalgia. A nostalgia reflexiva (reflexive), por sua vez, corresponde a memória coletiva e social e é a que interessa ter em mente para pensar o título do filme. A primeira tipologia equivale ao que o historiador Eric Hobsbawm denomina "invented traditions". Sua estrutura teleológica ergue grandes monumentos e tenta conquistar e espacializar o tempo. Por sua vez, a nostalgia reflexiva se estrutura em camadas múltiplas; tenta temporalizar os espaços, oferecendo a possibilidade de reimaginar o passado. Boym completa: "A retórica da nostalgia restaurativa não é sobre "o passado", mas, sim, sobre valores universais, família, natureza, pátria, verdade. A retórica da nostalgia reflexiva é sobre dar-se tempo a partir do tempo que passa e sobre segurar o tempo que se esvai" (Boym, 2007:14).

De fato, o termo reflexivo evoca a imagem-cristal que discutimos anteriormente. Em vez de procurar conhecer o passado "como ele de fato foi", para usar novamente a fala de Benjamin, a nostalgia reflexiva que Boym elabora uma meditação sobre o mundo histórico e sobre a passagem do tempo que o sujeito invariavelmente vivenciou. Novamente o passado e o presente se refletem 
mutuamente, a nostalgia de seu filme não quer reconstruir o passado que deixou de existir, sua narrativa é uma revisitação através dos espaços, inconclusiva e fragmentaria. É nas ruínas que sua nostalgia habita e que emerge conforme seus gestos arqueológicos; o deserto é um imenso arquivo a céu aberto que conserva os traços de uma história que vai muito além deu seu espaço geográfico.
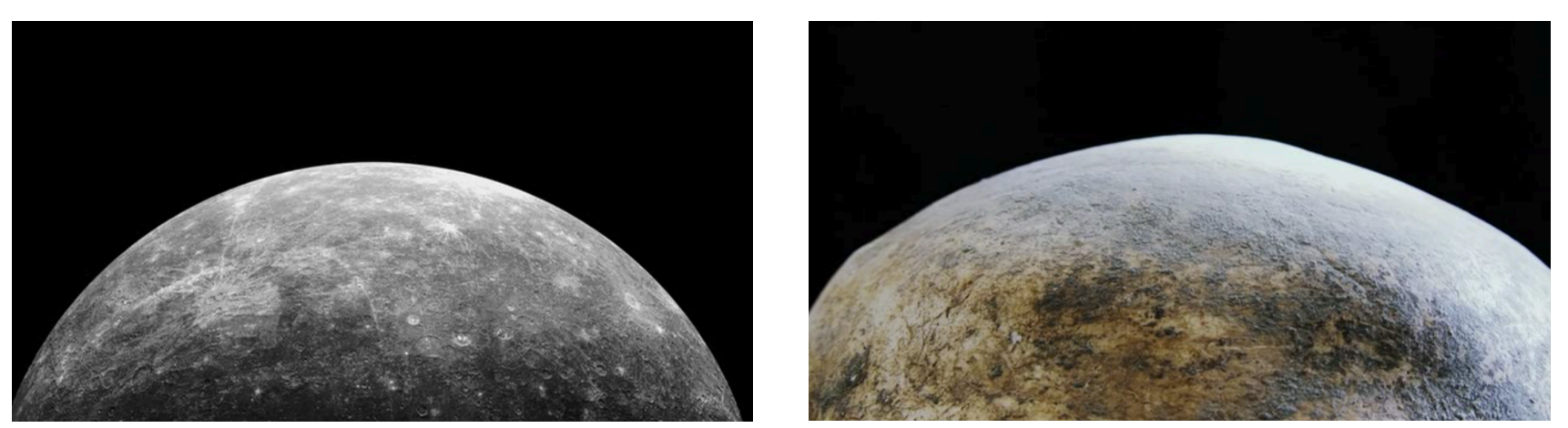

Figuras 43 e 44: Imagem da superfície lunar seguida da imagem da superfície de um crâneo: representação do cálcio que constitui ambos.

Isis Sadek comenta que Nostalgia da Luz, ao conseguir devolver a carga traumática ao deserto, converte esse espaço "em um museu que recupera o passado, trabalhando contra a sua invisibilização e construindo esse lugar em arquivo da memória que reúne os rastros da experiência deste lugar em distintas épocas históricas" (Sadek, 2012:63). De fato, essa é uma dimensão que existe nos museus, no entanto, Guzmán não se mostra satisfeito com essas instituições que armazenam um passado sem conseguir articular o pensamento com o presente. Sua crítica está presente, como já visto, em seu filme Salvador Allende, quando, após ele manipular alguns objetos pessoais do ex-presidente, comenta: "Rastreando em museus e arquivos, hoje, somente esse único fragmento [os óculos de Salvador Allende] é visível ao público". O diretor parece dar uma importância especial aos espaços destinados aos arquivos mais do que os museus propriamente dito. O arquivo no Chile foi um espaço de resistência. Em seu filme $O$ caso Pinochet, são os arquivos que se conservaram graças ao trabalho da Vicaría de la Solidaridad, um organismo da Igreja Católica que prestou assistência às vítimas durante a ditadura militar, que tornaram possíveis os processos jurídicos no futuro. Em seu outro filme En nombre de Dios (1985-86), podemos ver o importante trabalho da Vicaría de la Solidaridad, que era formada por uma equipe de assistentes sociais e advogados que defendiam os presos em tribunais e seguiram ajudando na busca dos corpos dos que desapareciam, e, que possuíam a prática de armazenar 
cautelosamente todos as informações possíveis das vítimas. São essas salas abarrotadas de arquivos que retornamos a ver em Chile, memória obstinada.

Em Nostalgia da Luz, novamente há uma crítica nesse sentido. Após mostrar uma sala destinada à conservação dos corpos de múmias de 10.000 mil anos, Gusmán diz: "Eles foram estudados como as páginas de um livro raro e hoje os conservam como se fosse um tesouro." Ele filma a ossada de uma baleia que existe em um museu ao qual sua mãe o levava quando criança. Depois de um lento movimento de câmera que percorre as costelas dessa baleia, vemos novamente um local de conservação, com grades prateleiras e caixas de papelão. Guzmán inicia sua reflexão sobre esses locais que acaba de filmar:

Hoje em dia existem outros ossos que não estão em nenhum museu. São de cálcio, o mesmo cálcio de que são feitas as estrelas. Mas, ao contrário delas, eles não têm nomes, não se sabe a que alma pertenceram. São restos de restos. Restos dos desaparecidos da ditadura militar que ainda esperam serem identificados. Eu me pergunto: 'quanto tempo eles descansarão nestas caixas?' 'Algum dia serão depositados em um monumento?' 'Terão direito a um museu assim como a baleia?' 'Algum dia terão sepultura?'.

De alguma forma, o filme consegue mais do que a instituição museu, que Guzmán implicitamente critica, porque o documentario conserva em suas imagens o passado tanto ressignificando-o para o espectador quanto refletindo sobre ele com o espectador, que recebe essas imagens no momento presente.

Por fim, mesmo após esses questionamentos que parecem não ter resposta imediata, o filme tem dois momentos reconfortantes e que aspiram esperança de um futuro melhor.

O primeiro é o relato de Valentina Rodríguez. Ela, assim como jovem Víctor, também trabalha com astronomia, mas, diferente dele, Valentina cresceu sem os pais, que desapareceram quando ela tinha um ano de idade. Guzmán filma os avós que a criaram, mas eles não falam: enquanto os vemos sentados no sofá encarando a câmera de frente, o que escutamos é a voz de sua neta. Ela nos conta que, após serem detidos, os militares ameaçaram matar a menina, caso seus avós não revelasse a localização de seus pais. A astronomia aparece novamente como um fator terapêutico - ela diz: "A astronomia me ajudou a dar uma outra dimensão à dor, à ausência, à perda." Em seguida, ela mostra seu filho e demonstra 
felicidade por ele não ter o "defeito de fábrica" que ela tem por ter crescido sem os pais.

O segundo momento é quando vemos o astrônomo Gaspar Galaz com Vicky e Violeta Bérrios em torno de um telescópio. Em entrevista Guzmán comenta como foi organizar esse encontro:

Eu gostaria de falar sobre essa sequência. Eles estavam muitos apreensivos para se encontrarem. As mulheres diziam: "nos não temos nenhuma educação, nós não temos nada em comum com esse astrônomo". E Gaspar também estava: "Eu sou um intelectual, eu não tenho nada em comum com essas mulheres do deserto." Eu estava no meio disso tudo, tentando unir esses dois lados. Então, quando eles se encontraram, pela primeira vez, havia tensão. Mas tudo mudou quando Gaspar disse para as elas que a lua tem sido testemunha das ações humanas há milhares de anos e que sabia onde seus parentes desaparecidos estão. Dessa forma, dá próxima vez que elas vissem a lua, disse ele, elas poderiam perguntar onde estão os resquícios de seus entes queridos. Basicamente, isso quebrou o gelo (Guzmán, $2011, \mathrm{~s} / \mathrm{p})$.

No entanto, essa sequência não possui falas, apesar de vermos suas bocas conversando. A trilha sonora se sobrepõe; imaginamos a conversa e vemos seus sorrisos enquanto as duas olham o céu através do telescópio. O 'pó cósmico' reaparece, tomando conta do ambiente (impossível não lembrar da bola de vidro/"Rosebud", com seus flutuantes flocos de neve, do Cidadão Kane). Um corte. A câmera percorre bolinhas de gudes dos mais variados tamanhos e cores que aparecem imóveis em cima de uma superfície de madeira, ouvimos em off: "Fazendo esse filme, olhando para trás, essas bolinhas também recordam a inocência do Chile durante a minha infância. Nessa época, cada um de nós poderia guardar, no fundo de seus bolsos, o Universo inteiro." A trilha se dissipa lentamente até começarmos a ouvir uma sirene ao fundo. Vemos a imagem de Santiago à noite, cuja luzes das casas e ruas mais parecem o universo com suas estrelas e galáxias. "Estou convencido de que a memória tem uma força de gravidade. Ela sempre nos atrai. Os que têm memória são capazes de viver no frágil tempo presente. Os que não a têm não vivem em nenhuma parte.” Após uma breve pausa, que torna mais evidente o som longínquo da cidade, Guzmán finaliza: "Cada noite, lentamente, impassível, o centro da galáxia passa por cima de Santiago." 


\section{4. \\ Considerações finais}

Há no trabalho de Guzmán, como mencionamos no capítulo 2, o que se tem chamado de dever de memória. Seus filmes, com recursos narrativos múltiplos, elaboram o passado histórico e seus sofrimentos. Para Beatriz Sarlo, a atividade de "lembrar" é, em países que passaram por violentas ditaduras - como Chile, Argentina e Brasil -, necessária para restaurar os "laços sociais e comunitários perdidos no exílio ou destruídos pela violência de Estado" (Sarlo, 2007:45). Chile, memória obstinada, o primeiro filme feito por Guzmán depois de voltar do exílio na França, em 1996, busca não só olhar para o passado, mas exatamente unir, ou mesmo reunir, as pessoas que por tanto tempo permaneceram separadas. O documentário abre um espaço comum para que, muitas vezes coletivamente, essas pessoas, antes exiladas ou silenciadas, falem de suas memórias. Dessa forma, o ato de testemunhar ganha força. Guzmán, ao ligar uma câmera, se torna um ouvinte e também um agente transmissor dessas histórias, possibilitando, para essas pessoas que voltam a falar, um novo sentido para o ato de testemunhar: trata-se de praticar, registrando essa própria prática, o tão fundamental dever de memória.

Portanto, o cinema arqueológico está invariavelmente voltado para o passado, no importante papel de revisitar a história e as memórias que a compõem. Em uma perspectiva mais ampla, concluímos que a obra documental de Guzmán é um grande gesto arqueológico, justamente pelo modo que ele organiza e seleciona o material de arquivo, estuda esse passado, corta os planos e os dispõem na montagem final do filme. No entanto, o gesto arqueológico não está apenas na estrutura do documentário, mas também nas próprias ações dos personagens (isso inclui o diretor) e dos locais explorados. São os vestígio e rastros que originam muitas vezes o discurso sobre os acontecimentos passados. A frase de Benjamin, no texto "Sobre o conceito da história", que diz ser necessário escovar à contrapelo a nossa história é uma rica imagem para pensarmos o trabalho arqueológico que Guzmán faz no Chile: coletando, reunindo e, assim, preservando vozes que não foram prestigiadas pela História Oficial.

Devemos considerar também seu trabalho à frente do Festival Internacional de documentários de Santiago do Chile (FIDOCS), fundado em 1997, do qual é presidente até os dias de hoje. O festival se tornou um espaço alternativo para a exibição de documentários que os canais de televisão não transmitem. 
Eu queria mostrar ao público de Santiago a ampla produção documental que eu tive sorte de ver e apreciar durante minha vida no estrangeiro, sobretudo, mostrar aos jovens diretores e produtores chilenos, já que durante muito tempo nenhum canal de televisão local mostrou a enorme produção europeia. Ao contrário, minha geração teve uma experiência distinta. Nas décadas de 50 e 60, quando eu era adolescente, chegaram ao Chile muitas obras documentais importantes. Mas depois do golpe militar e durante os primeiros anos da transição democrática (quase 25 anos), o Chile perdeu quase todo o contato com a produção documental mundial (Guzmán, 2005: s/p).

Mesmo sendo uma figura proeminente do documentário mundial, Patricio Guzmán teve seu filme Nostalgia da Luz (2010) recusado por 15 canais de televisão europeus. No artigo La odisea financeira de Nostalgia de la Luz (2011), ele comenta:

Eu creio que é difícil que uma indústria possa se manter com vida, expulsando uma parte de seus autores. Nos empurram um tema e um estilo predeterminados. Isso nos obriga a mudar de personalidade, nos obriga a olhar a realidade em olhos emprestados. Ou temos que aceitar uma forma de submissão ou nos retiramos em uma forma de exílio (...) Meu mundo está em perigo e tem muitos realizadores como eu na França (e em outros países) que também estão em perigo. Estamos imersos em um grande rio, em uma grande torrente "de cada vez mais de tudo": mais público, mais audiência, mais concessões, mais rapidez, mais modernidade. E tudo o que não é "mais" vale menos (Guzmán, 2011.c: s/p)

Guzmán critica fortemente a postura da televisão convencional de não valorizar os filmes documentais com maiores recursos narrativos, no qual se trabalha fortemente com um ponto de vista pessoal do cineasta, o que Guzmán chama de "documentários de autor". Dessa forma, o FIDOCS, que surgiu em uma época onde a internet não estava disseminada ainda, foi por muito tempo a única maneira de combater a fraca programação cultural da televisão: “Criar um público documental é muito lento e criar um público cultural - em uma televisão mercantil - é ainda mais" (Guzmán, 2011:s/p). Recentemente, Guzmán chegou até mesmo a enviar uma carta aberta ao diretor executivo da TVN acusando o canal de "sabotar" seu filme Nostalgia da Luz'.

${ }^{29} 0$ diretor questiona a omissão dos 35 minutos iniciais do filme além da exibição de fragmentos de cenas dispersas e alguma delas se repetindo por duas vezes. Carta completa disponível em: http://corporacionculdoc.wordpress.com/2013/08/01/carta-abierta-depatricio-guzman-dirigida-al-senor-mauro-valdes-director-ejecutivo-de-tvn/ (acessado em $5 / 02 / 2014)$ 
Ainda com relação ao filme, pode-se pensar que ele faz parte de um projeto mais amplo. Seu processo de produção gerou outros projetos fílmicos de menor duração, que podem ser visto nos extras de seu DVD e que foram exibidos em festivais. São os curtas metragens: Chile, una galaxia de problemas, Astronomos de mi barrio, Maria Teresa y la enena marron, Oscar Saa, el técnico de la estrelas e José Maza, el viajero del cielo.

Há nos curtas das semelhanças estéticas e técnicas - o uso da mesma trilha sonora, das mesmas fotografias astronômicas, mesma fonte de texto dos letterings -, o que se deve à utilização da mesma equipe; no entanto, Nostalgia da Luz, que é a obra principal do DVD, não visa nunca uma descrição explicativa e didática das operações dos observatórios e dos fenômenos do universo como se pode ver nos extras. Ainda assim, os curtas apresentam questões que permeiam as discussões levantadas pelo filme e, de alguma forma, ao se centrarem em temáticas mais específicas, acabam por ampliar a compreensão do tema e também por suscitar novos debates.

No entanto, podemos apontar como uma exceção o filme Chile una galáxia de problemas (2010), que, diferente dos outros, se passa em Santiago do Chile e sua linha temática foge à cosmologia ao discutir o período de transição democrática no país. Logo nas primeiras cenas vemos um plano geral da cidade, do Rio Mapocho (local onde muitos corpos de presos políticos ressurgiram flutuando), do topo de prédios modernos e finalmente do interior do Museu da Memória e dos Direitos Humanos, inaugurado em janeiro de 2010 pela presidente Michelle Bachelet. Guzmán volta a entrevistar o arquiteto Miguel Lawner - que comenta uma outra dimensão do processo de obliteração da memória: as obras de artes desaparecidas do edifício da UNCTAD ${ }^{30}$. Também entrevista o ex-chefe do exército J. E. Cheyre, que, com palavras vagas, reconhece as violações dos direitos humanos perpetrados pela instituição.

Esta pesquisa, de modo geral, analisou com mais ênfase os longasmetragens que Patricio Guzmán realizou a partir da década de 90; neles, ele

\footnotetext{
${ }^{30} \mathrm{O}$ edifício foi criado para abrigar a terceira Conferência Mundial de Comércio e Desenvolvimento das Nações Unidas (UNCTAD), em 1972. Após o evento o prédio foi nomeado como Centro Cultural Metropolitano Gabriela Mistral. No entanto, após o golpe de 1973, o edifício foi rebatizado como "Diego Portales". Somente em 2009, no governo de Michelle Bachelet, o prédio voltou a ter o nome da Prêmio Nobel chilena.
} 
compõe sua narrativa enfocando particularmente a questão das memórias coletivas de grupos vitimados pela ditadura de Pinochet. É dessa forma que o testemunho oral ganha importância na construção de uma nova história, pois procura dar voz aos excluídos e compreender a trajetória dos grupos dominados, tirando "do esquecimento o que a história oficial sufocara durante tanto tempo" (Ferreira, 2002:322). Ao enveredar pelas histórias orais de pessoas, se está, invariavelmente, caminhando para o campo do discurso da memória, ou seja, se está propondo uma construção do passado pautado mais nas emoções e vivências do que em um posicionamento racional e expositivo da história. O passado, é claro, não é fixo. Como já anunciava Halbwachs no começo do século XX, a memória é fruto de uma constante rememoração, nós não lembramos das imagens do passado exatamente como elas ocorreram, tal como se ficassem estocadas em nosso subconsciente, prontas para serem evocadas de forma plena e íntegra a qualquer momento. A nossa memória, que é também a memória coletiva dos grupos pelos quais transitamos, são imagens do passado não na forma como aconteceram, mas sim a partir do presente e das forças sociais que agem sobre nós. Portanto, os documentário de Guzmán, ao captarem e se apropriarem dessas memórias, põem em marcha "uma reconstrução do passado com ajuda dos dados emprestados do presente", sejam esses dados o próprio ato de testemunhar no presente sejam eles os vestígios que residem pelos espaços que percorremos (Halbwachs, 2004:75).

Vimos que existe no trabalho de Guzmán, a partir, principalmente, de $O$ caso Pinochet, o que identificamos como um gesto arqueológico, onde ele ou seus personagens confrontam fisicamente a paisagem atual na busca de rastros - muitas vezes provenientes do próprio processo violento - que possam esclarecer e configurar melhor o passado.

É notável o trabalho mais pessoal, mais performático - para usar novamente o termo de Bill Nichols - que vemos aflorar desde Pueblo en Vilo (1995), com a utilização da narração em off do diretor, e Chile, memória obstinada (1997), com sua aparição física à frente das câmeras, assim como dos atos corporalizados de memória que vemos ao longo do filme.

De fato, outros filmes como La Isla de Robinson (1999) e Mi Jules Verne (2005), também trazem esse aspecto pessoal e subjetivo. Inclusive, podemos encontrar semelhanças: por exemplo, em uma sequência de Mi Jules Verne que, anos depois, será reformulada em Nostalgia da Luz. Refiro-me à sequência (a 
primeira do filme) que remonta à infância de Guzmán; em Mi Jules Verne, vemos uma longa montagem de planos de uma casa provinciana de Viña del Mar, cidade onde Guzmán morava quando tinha 10 anos - a casa "misteriosa", como descreve o diretor, pertencia a Carmen, sua professora particular em que ia duas vezes por semana. O universo nostálgico é evocado pelos planos dessa casa vazia, lugar em que aprendeu a olhar mapas-múndi e ler os livros traduzidos para o espanhol de Júlio Verne. Em seguida, vemos seu dedo indicador (já envelhecido) percorrendo em um mapa as capitais Santiago do Chile, Paris e Madrid, locais nos quais viveria (e viveu) ao longo de sua vida. Interessante notar que em Nostalgia da Luz, Guzmán faz referência a esses livros quando diz: "Eu amava os contos de ficção científica, os eclipses da lua ...”. De fato, Mi Jules Verne já antecipa, antes de Nostalgia da Luz, essa paixão pelo universo e suas galáxias - ao comentar o livro de Júlio Verne, De la Terre à la Lune (1985), Guzmán entrevista um astronauta e um astrônomo e compõe a narrativa com imagens do espaço (muito semelhantes às imagens de seu filme mais recente) e também do lento funcionamento de um observatório.

Atualmente, Guzmán está em fase de produção do documentário El botón de nácar, que será o segundo filme da trilogia iniciada com Nostalgia da Luz. Trata-se de um documentário que relaciona a história recente dos desaparecidos com o extermínio de seis etnias magallánicas no sul do Chile durante o século XIX.

Por fim, e não é demais lembrar essa questão, é importante compreender o documentário como resultado de uma representação da realidade e não como uma "janela" de acesso à essa realidade. Dessa forma, o trajeto de vida de Patricio Guzmán, a experiência do exílio - o sentir-se estrangeiro por onde transitava, bem como sua nostalgia pelos lugares, objetos e figuras do passado - é parte constituinte de seu cinema. Seus documentários não falam apenas do mundo que está do lado de fora, lá em frente da lente, porque, mais do que filmar o real, o documentário se torna uma reflexão sobre o próprio cinema. Essa reflexão é algo que Guzmán não cessa de exercitar. No texto La importância del cine documental (1997), Guzmán argumenta que cada cultura possui uma maneira distinta de se expressar, de modo que cada documentário assumiria um papel importante na constituição de uma voz única e diferenciada dessa cultura. No entanto, ele chama 
atenção também para o fato de países estrangeiros possuírem mais material documental que nossa cultura (latino-americana).

... documentários sobre o deserto de Atacama, sobre a selva brasileira, sobre a guerra civil espanhola, sobre Mariscal, sobre Dalí, sobre Picasso, sobre El Joglars, sobre o rei Juan Carlos, sobre a Rota dos Incas, sobre o flamenco, o tango e a salsa, sobre Neruda, Botero, Borges, sobre a ilha Robson Crusoé, sobre a arquitetura de Chiloé, sobre as ruinas de Nazca, sobre a cozinha africana da Bahia, sobre os bulevares de São Paulo, sobre o artista plástico Antonio Saura, etc., são, por regra geral, grandes obras documentais alemãs, holandesas ou francesas (Guzmán in Ruffinelli, 2001 [1995]:395).

Patricio Guzmán, com sua complexa linguagem indo do factual ao meditativo, da agitação da câmera movendo-se entre as pessoas na multidão ao grande plano contemplativo das galáxias, é, sem dúvida, um dos grandes documentaristas contemporâneos. Suas obras mais recentes, em especial Nostalgia da $L u z$, reelaboram de forma criativa nossa memória histórica e visual, além de possibilitar uma compreensão mais honesta e um questionamento tanto inquietante quanto sereno acerca do passado recente e do que está por vir, levando-nos a refletir sobre a possibilidade de um futuro mais solidário e pleno de direitos a todos. 


\section{5.}

\section{Filmografia}

Viva la liberdad

Chile, 1965. 20 minutos. Diretor: Paticio Guzmán.

\section{Electroshow}

Chile, 1966. 14 minutos. Diretor: Patricio Guzmán. Roteiro: Patricio Guzmán e Eduardo Stagnaro. Fotografia: René Kocher. Produtor: Instituto Fílmico de la Universidad Católica.

El paraíso ortopédico

Espanha, 1969. 37 minutos. Diretor: Patricio Guzmán. Roteiro: Jorge Díaz com a colaboração de Patricio Guzmán. Fotografia: Enrique Banet. Produtor: EOC.

Chile, eleccions municipales

Chile, 1971. 10 minutos. Diretor: Patricio Guzmán. Filme desmontado e incluído na primeira parte de $A$ Batalha do Chile.

El primer año

Chile, 1972. 100 minutos, $16 \mathrm{~mm}$ ampliado para $35 \mathrm{~mm}$. Diretor e roteiro: Patricio Guzmán. Fotografia: Gustavo Moris; Jorge Müller Silva; Pablo Perelman; Fernando Campos; Mario Rojas. Produtor: EAC, Artes de la Comunicación, Universidad Católica.

La respuesta de octubre

Chile, 1972. 40 minutos. Diretor: Patricio Guzmán. Fotografia: Jorge Müller Silva. Produção: Federico Elton. Filme desmontado e incluído na terceira parte de $A$ Batalha do Chile.

La batalha de Chile I. La insurrección de la burguesia Cuba, 1975. 97 minutos.

La batalha de Chile II. El golpe de estado 
Cuba, 1976. 89 minutos.

La batalha de Chile III. El poder popular

Cuba, 1979. 79 minutos. Diretor: Patricio Guzmán. Roteiro: Patricio Guzmán com a colaboração de Pedro Chaskel, José Bartolomé, Julio García Espinosa, Federico Elton, Marta Harnecker, Chirs Marker. Fotografia: Jorge Müller Silva. Som direto: Bernardo Menz. Assistente de direção: José Bartolomé. Montador: Pedro Chaskel. Produção: Federico Elton.

La rosa de los ventos

Venezuela-Cuba-Espanha, 1982. 70 minutos. Diretor: Patricio Guzmán. Roteiro:

Patricio Guzmán; Gloria Laso; Jorge Díaz. Colaboradores: Nelson Rodríguez, Eduardo Galeano, Jorge Fraga, Julio García Espinosa, Lina Baniela. Fotografia: Pablo Martínez. Som: Raúl García. Montador: Nelson Rodríguez. Produção: Paraíso Films (Espanha) - ICAIC (Cuba) - Universidad de los Andes (Mérida, Venezuela).

En nombre de Dios

Chile-Espanha, 1986. 97 minutos. Diretor e roteiro: Patricio Guzmán. Fotografia: Jaime Reyes e José Cobos. Som direto: Mario Díaz. Música: José Antonia Quintano. Montagem: Luciano Berriatúa. Produtor: Arturo Feliú para a Televisión Española S.A e Patricio Guzmán.

\section{México precolombino}

Espanha, 1987. 150 minutos (5 episódios de 30 minutos). Diretor e roteiro: Patricio Guzmán. Fotografia: Lorenzo Cebrián. Locutor: Francisco Valladares. Montagem: Manuel García. Produtor: José Ricart - TVE S.A.

\section{El proyecto ilustrado de Carlos III}

Espanha, 1988. 240 minutos (4 episódios de 60 minutos). Diretor: Patricio Guzmán. Roteiro: Ramón Guerra e Patricio Guzmán. Fotografia: José F. Aguayo. Música: José Antonio Quintano. Montador: Angel Sandin. Narrador: Luis Porcar. Produtor: Jesús Jiménez e Javier González. 
La Cruz del Sur

Espanha, 1992. 80 minutos (versão para TV de 3 episódios de 60 minutos cada um). Diretor e roteiro: Patricio Guzmán. Narrador: Fernando Ulloa. Diretor de Fotografia: Antonio Ríos. Câmera adicional: Nelle Van Essen, Jaime Reyes, Nonato Estrela (Brasil), Peter Chappel, Jaime Reyes (Equador), Peter Chappel (Guatemala), Reuben Aaronson (Peru), Tony Kuhn, Eric Gorthals (México). Montador: Marcelo Navarro. Música: José Antonio Quintano. Produção: Quasar Films S.A. (Madrid)

\section{Pueblo en Vilo}

México, 1996. 52 minutos. Diretor: Patricio Guzmán. Roteiro: Patricio Guzmán sobre o livro Pueblo en Vilo de Luis González. Locutor: Patricio Guzmán. Fotografia: Eric Pittard. Música: Béatrice Thiriet. Som: André Rigaut. Montagem: Catherine Mibaliat. Assistente de direção: Andrea J. Guzmán. Produção: Yves Jeanneau para o France-2.

Chile, la memoria obstinada

Chile, 1997. 57 minutos. Diretor: Patricio Guzmán. Fotografia: Eric Pittard. Música: Robert M. Lepaige. Som: Boris Herrera. Montador: Hélène Girard. Narrador: Patricio Guzmán. Produção: Films d'Ici-National Film Board de Canadá-La Sept-ARTE.

La isla de Robinson Crusoe

Chile, 1999. 42 minutos. Diretor, roteiro, fotografia e som: Patricio Guzmán. Montador: Catherine Mabilat. Música: Jorge Arriagada. Produção: JBA Production (Jacques Bidou)- La Sept-ARTE (Delphine Coulin)- Centre National de la Cinématographie.

\section{El caso Pinochet}

França, 2001. 108 minutos. Direção, roteiro e narrador: Patricio Guzmán. Fotografia: Jacques Bouquin. Montagem: Claudio Martínez. Som: André Rigaut. Assistente de direção: Camila Guzmán. Produção: Les Films d'Ici. 
Salvador Allende

Chile, 2004. 100 minutos. Direção, roteiro e narrado: Patricio Guzmán. Fotografia: Patricio Guzmán e Julia Muñoz. Montador: Claudio Martinez. Som: Álvaro Silva Wuth. Assistente de direção: Andrea Guzmán. Produção: JBA Productions.

\section{Mi Jules Verne}

Chile, 2005. 58 minutos. Diretor, roteiro e narrador: Patricio Guzmán. Fotografia: Jacques Bouquin. Som: André Rigaut. Montador:Eva Feigeles. Musica: Jorge Arriagada. Assistente de direção: Camila Guzmán. Produção: Ex Nihilo para o ARTE.

\section{La Nostalgia de la Luz}

Chile, 2010. 90 minutos. Diretor, roteiro e narrador: Patricio Guzmán. Fotografia:

Katell Dijian. Montador: Patricio Guzmán e Emmanuelle Joly. Som: Freddy González. Música: Miranda \& Tobar. Produção: Renate Sachse, Meike Martens, Cristóbal Vicente 


\section{6. Referência Bibliográfica}

AGAMBEN, Giorgio. O que resta de Auschwitz: $O$ arquivo e a testemunha. (trad. Selvino J. Assmann. São Paulo: Boitempo, 2008

AGGIO, Alberto. Democracia e socialismo no Chile: a experiência chilena. São Paulo: Annablume, 2002.

AGUIAR, Carolina Amaral. O Chile na obra de Chirs Marker: um olhar para a Unidade Popular desde a França. Tese apresentada ao Programa de PósGraduação em História Social (USP). São Paulo. 2013

ALMEIDA TELLES, Janaína. Os trabalhos da memória: os testemunhos dos familiares de mortos e desaparecidos políticos no Brasil em Escritas da violência, vol. 2: representações da violência na história e na cultura contemporânea da América Latina. Rio de Janeiro: 7Letras, 2012, p.109-118

ARENDT, Hannah. Origens do Totalitarismo. São Paulo: Companhia das Letras, 1989.

AVELLAR, Idelber. Alegorias da derrota: a ficção pós-ditatorial e o trabalho de luto na América Latina. (trad. Saulo Gouveia). Belo Horizonte: Editora UFMG, 2003

BARAHONA DE BRITO, Alexandra, FERNÁNDEZ, Paloma Aguiar \& ENRÍQUEZ, Carmen Gonzáles (eds.). Las políticas hacia el passado: juicios, depuraciones, perdón y olvido em las nuevas democracias. Edição Istmo, Madrid., 2002 (Introdução)

BARTHES, Roland. A Câmara Clara. Lisboa: Edições 70, 2006

BELLOUR, Raymond. Entre-imagens: foto, cinema, vídeo. São Pulo: Papirus, 1997

BENJAMIN, Walter. Magia e técnica, arte e política. Ensaios sobre literatura e história da cultura, vol. 1. (prefácio de Jeanne Marie Gagnebin). São Paulo: Brasiliense, 1987.

BERNARDET, Jean-Claude. Cineastas e imagens do povo. São Paulo: Companhia das Letras, 2003

BOYM, Svetlana. Nostalgia and Its Discontentes. In: The Hedgehog Review, verão de 2007, pp. 7-18

BURKE, Peter. Testemunha ocular: história e imagem. (trad. Vera Maria Xavier dos Santos), Bauru: EDUSC, 2004. 
CELIS, Andrés \& Santiago Rubín de. Los desafios de la realidade. Una entrevista con Patricio Guzmán. Doc On-line, ${ }^{\circ} 8$, Agosto de 2010, pp. 254-274 COMOLLI, Jean-Louis. Ver e Poder - A inocência perdida: cinema, televisão, ficção, documentário. Belo Horizonte: Editora UFMG, 2008

DANEY, Serge. A Rampa. Ed: Cosac Naify, São Paulo, 2007.

DELEUZE, Gilles. A imagem-tempo. (trad. Eloisa de Araujo Ribeiro). São Paulo: Brasiliense, 2007

DIDI-HUBERMAN, Georges. Cuando las imagenes tocan lo real, 2007

Disponível em: http://www.macba.es/uploads/20080408/Georges_Didi_Huberman_Cuando_las_i magenes_tocan_lo_real.pdf(acessado em 12/12/2013)

Images in spite of all: four photographs from Auschwitz. (Trad. Shane B. Lillis), The University of Chicago, 2008

DOANE, Mary Ann. A voz do cinema: a articulações de corpo e espaço em A experiência do cinema. Ismael Xavier (org.). Edições Graal, São Paulo, 2003, p.457-477

ESPINOSA, Julio. Por un cine impercfecto em Hablemos de cine. $\mathrm{n}^{\mathrm{o}}$ 55/56, Lima, set/dez, 1970. pp. 37-42.

FERREIRA, M.F. História, tempo presente e história oral. In: Topoi, Rio de Janeiro, dezembro 2002, pp. 314-332

FICO, Carlos. História do Tempo Presente, eventos traumaticos e documentos sensíveis: o caso brasileiro em VARIA HISTORIA, Belo Horizonte, vol.28, nº47, jan/jun 2012, p. 43-59

GAGNEBIN, Jeanne Marie. Apagar os rastros, recolher os restos em Walter Benjamin: rastro, aura e história. Sabrina Sedlmayer, Jaime Ginzburg (orgs.). Belo Horizonte: Editora UFMG, 2012, p.27-38

2006

Lembrar, escrever, esquecer. São Paulo: Ed. 34,

GAUTHIER, Guy. O documentário: um outro cinema. (tradução Eloisa Araújo Ribeiro). Campinas: Papirus, 2011

GINZBURG, Jaime. A interpretação do rastro em Walter Benjamin em Walter Benjamin: rastro, aura e história. Sabrina Sedlmayer, Jaime Ginzburg (orgs.). Belo Horizonte: Editora UFMG, 2012, p.107-132

p.131-146

. Escritas da Tortura. Diálogos Latinoamericanos, nº 3, 2001, 
GOMES, Paulo Emílio Salles. Cinema: trajetória no subdesenvolvimento. São Paulo: Paz e Terra, 1986

GÓMEZ-BARRIS, Macarena. Where Memory Dwells: culture and state violence in Chile. Berkeley: University of California Press, 2009

GUZMÁN, Patricio. Entrevisa a Patricio Guzmán: "Más vale una sólida formación política que la destreza artesanal” por Sergio Salinas e Héctor Soto. Revista Primer Plano, $\mathrm{n}^{\circ} 5$, verão de 1973. Disponível em www.cinechile.cl/archivo-32 (acessado em 02/01/2014)

1993. Conversations with Patricio Guzmán por Jorge Ruffinelli,

Disponível em: http://www.patricioguzman.com/index.php?page=entrevista\&aid=11 (acessado em 28/10/2013)

Los desafios de la realidad. Una entrevista con Patricio Guzmán por Andrés \& Santiago Rubín de Celis. Doc On-line, n ${ }^{\circ}$, Agosto de 2010, p. 254-274

Desert of disappeared: Patricio Guzmán on Nostalgia for the Light por Chirs Darke. Paris, agosto de 2012a.

Disponível em https://www.bfi.org.uk/news/sightsound/patricio-guzmanextended-interview (acessado em 08/12/2013)

After-effects: Interview with Patricio Guzmán por Rob White. Londres, fevereiro de 2012.b

Disponível em: http://www.filmquarterly.org/2012/07/after-effects-interviewwith-patricio-guzman/ (acessado em 08/12/2013)

Lo que debo a Chris Marker. Agosto de 2012.c, Paris. Disponível em http://www.cinechile.cl/crit\&estud-220 (acessado em 05/12/2013)

Patricio Guzmán recibe apoyo de Sundance para su próximo documental por El Mercurio Online. Nova Iorque, novembro de 2008. Disponível em http://www.emol.com/noticias/magazine/2008/11/27/332711/patricio-guzmanrecibe-apoyo-de-sundance-para-su-proximo-documental.html (acessado em $11 / 01 / 2014)$

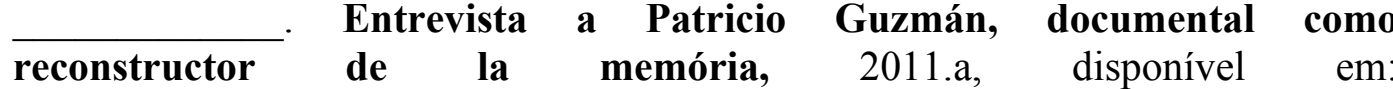
http://www.youtube.com/watch?v=yBJ9UrnpL80 (acessado em 13/12/2013)

Patricio Guzmán, Nostalgia for the Light por Damon Smith, março de 2011.b. Disponível em http://filmmakermagazine.com/21520-patricioguzman-nostalgia-for-the-light/\#.Ut6LnmRpQnV (acessado em 18/01/2014)

. La odisea financeira de Nostalgia de la Luz, 2011.c, disponível em http://www.patricioguzman.com/index.php?page=articulos\&aid=28 (acessado em 05/01/2014) 
Festival en Chile. 2005, disponível em: http://www.patricioguzman.com/index.php?page=festival (acessado em 03/03/2014)

- Patricio Guzman: importanccia del Fidocs e imperdibles. Disponível em: http://www.youtube.com/watch?v=TDfIVlu69jI\#t=35 (acessado em 03/02/2014)

HALBWACHS, Maurice. A Memória Coletiva. São Paulo: Ed. Centauro, 2004

HIRSCH, Marianne. Surviving Images: Holocaust Photographs and the Work of Postmemory em Visual Culture and the Holocaust, Barbie Zelizer (ed.). New Brunswick, NJ: Rutgers University Press, 2001, p.146-214

HOBSWAWN, Eric J. O presente como história: escrever a história de seu próprio tempo. In: Novos Estudos CEBRAP, nº 43, novembro de 1995, pp. 103112

HUYSSEN, Andreas. Seduzidos pela Memória: arquitetura, monumento, mídia. Rio de Janeiro, Aeroplano Editora, Universidade Cândido Mendes, Museu de Arte Moderna-RJ, 2000

JANZ, Rolf-Peter, Sobre o paradoxo da aura e do vestígio em Walter Benjamin: rastro, aura e história. Sabrina Sedlmayer, Jaime Ginzburg (orgs.). Belo Horizonte: Editora UFMG, 2012, p. 13-26

LEGOFF, Jacques. História e memória. Tradução Bernardo Leitão. Editora da UNICAMP, Campinas, 1990

LEVI, Primo. Os afogados e os sobreviventes. (Trad. Luiz Sérgio Henriques). São Paulo: Paz e Terra, 2004

LINS, Consuelo. Passaporte Húngaro: cinema político e intimidade. Galáxia, Revista Transdisciplinar de Comunicação, Semiótica e Cultura, v.7. São Paulo: Programa de Pós-Graduação em Comunicação e Semiótica - PUC, 2004, p.75 84

MOUESCA, Jaqueline. Plano Secuencia de la Memoria de Chile. Veintecinco años de cine chileno (1960-1985). Madrid: Ediciones del litoral, 1988

. El documental chileno. Santiago: LOM Ediciones, 2005.

MACHADO, Roberto. Deleuze, a arte e a filosofia. Ed: Zahar, Rio de Janeiro, 2010

MOLFETTA, Andréa. Diário de viagem: o relato do indivíduo no documentário sulamericano. In: Revista Sinopse. São Paulo: INUSP, ano IV, $\mathrm{n}^{\mathbf{0}}$ 9, 2002

NICHOLS, Bill. Introdução ao documentário (tradução Mônica Saddy Martins). Campinas. SP: Papirus, 2005 
NORA, Pierre, Entre a Memória e História: A problemática dos lugares. (Trad: Yara Aun Khoury). In: Projeto História, São Paulo, dez.,1993

PADRÓS, Enrique Serra. A política de desaparecimento como modalidade repressiva das ditaduras de segurança nacional em Revista Tempos Históricos, volume 10 ( $1^{\circ}$ Semestre), 2007, p.105-129

Usos da memória e do esquecimento na História em Literatura e autoritarismo (revista eletrônica), $\mathrm{n}^{\mathrm{o}} 4$, 2002. Disponível em: http://w3.ufsm.br/grpesqla/revista/num4/ass02/pag01.html (acessado em 05/10/2013)

PENIDO, Stella. Walter Benjamin: a História como construção em revista $\mathrm{O}$ que nos faz pensar, $\mathrm{n}^{\circ} 1$, junho de 1989 , pg.61-70

PICK, Zuzana M. Chilean cinema: ten years of exile (1973-83) in: Jump Cut, n³2, Abril de 1987, pp. 66-70

POLLACK, Michael. Memória, Esquecimento, Silêncio. em Estudos Históricos, Rio de Janeiro, vol. 2, n. 3, 1989, pp. 3-15

RAMOS, Fernão Pessoa. Mas afinal...o que é mesmo documentário. São Paulo: Editora Senac São Paulo, 2008

RICOUER, Paul. Memory, history, oblivion, 2003. Versão online português em http://www.uc.pt/fluc/lif/publicacoes/textos_disponiveis_online/pdf/memoria_hist oria

ROCHA, Glauber. Uma estética da fome, Revista Civilização Brasileira, Rio de Janeiro, julho de1965.

RODRIGUES, José Carlos. Constantes e variáveis significacionais nos ritos e mitos associados à morte. XIX Encontro da Compós: Puc-Rio, 2010

RODRÍGUEZ, José Carlos. The postdictatorial documenraries of Patricio Guzmán: Chile, obstinate memory; The Pinochet case and Island of Robinson Crusoe. Tese de doutorado apresentado no departamento de Literatura da Graduate School of Duke University, 2007

ROUILLÉ, André. A fotografia: entre documento e arte conemporânea. (Trad. Constancia Egrejas). São Paulo: Editora Senac São Paulo, 2009

RUFFINELLI, Jorge. Patricio Guzmán. Madrid: Cátedra/Filmoteca Española, 2001

SADEK, Isis. Memoria espacializada y arqueología del presente en el cine de Patricio Guzmán. Revista Cine Documental, $n^{\circ} 8,2008$, p.28-71 
SANTOS, Myrian Sepúlveda dos. Memória coletiva \& teoria social. São Paulo: Annablume, 2003.

SARLO, Beatriz. Tempo passado: cultura da memória e guinada subjetiva. São. Paulo:Companhia das Letras, 2007

SELIGMANN-SILVA, Márcio. Reprodução técnica, os rastros efêmeros do desaparecimento e o "puro traço"na obra de Regina Silveira em Walter Benjamin: rastro, aura e história. Sabrina Sedlmayer, Jaime Ginzburg (orgs.). Belo Horizonte: Editora UFMG, 2012.a, p.259-320

. Narrativas contra o silêncio: cinema e ditadura no

Brasil em Escritas da violência, vol. 2: representações da violência na história e na cultura contemporânea da América Latina. Rio de Janeiro: 7Letras, 2012.b, p.6485

STAM, Robert. Introdução à teoria do cinema. Ed: Papirus, Campinas, 2006

TODOROV, Tzvetan. Los Abusos de la Memória. Ed: Paidós Ibérica, Barcelona, 2000

VASCONCELOS, Daniela. Autoritarismo, direitos humanos e redemocratizaçãoo: uma análise comparativa da justiça de transição do Brasil e na Argentina. Revista Andina de Estudios Políticos. Vol. III, nº1, 134165, 2013. 